
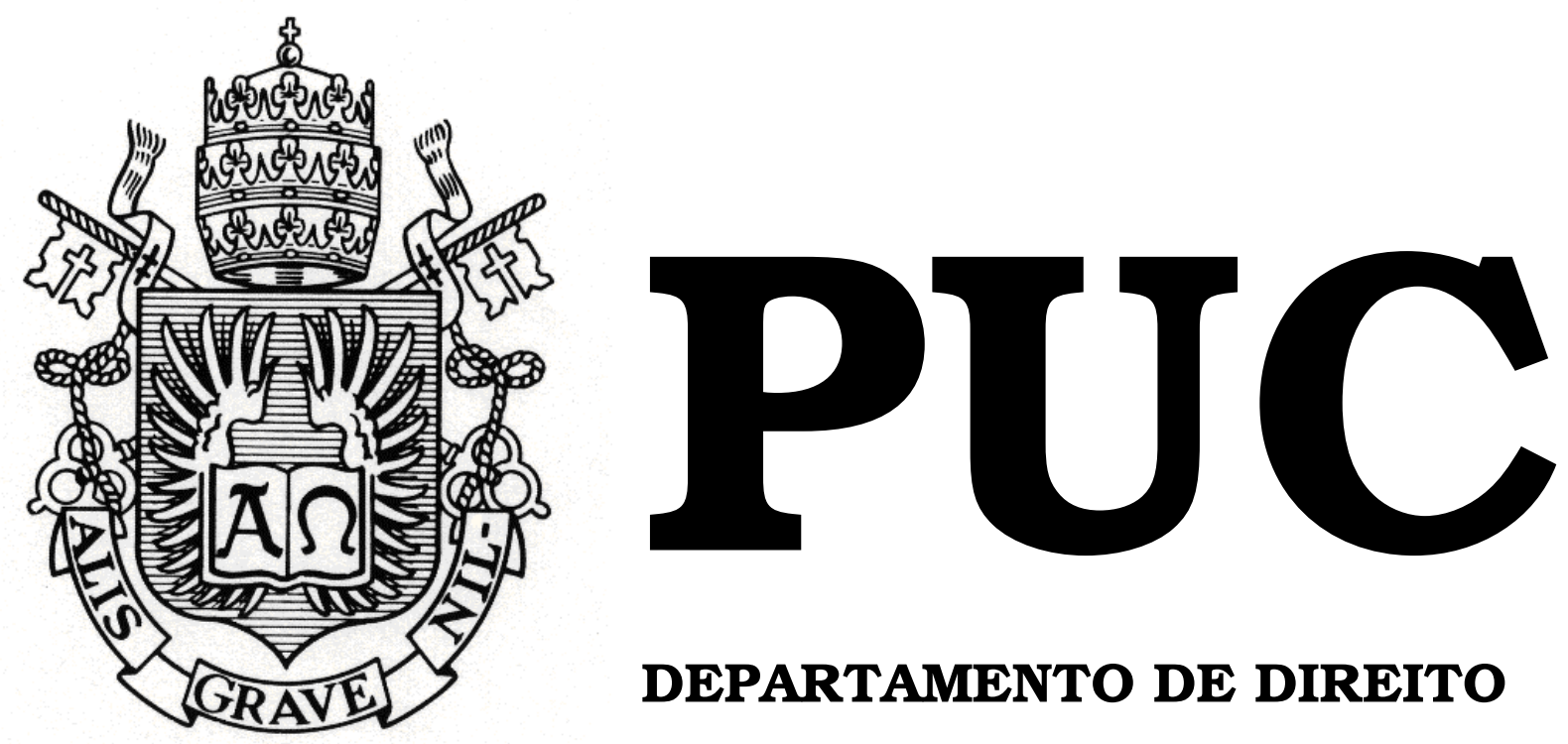

DEPARTAMENTO DE DIREITO

\title{
A VIDEOCONFERÊNCIA NO PROCESSO PENAL BRASILEIRO
}

por

THIAGO DE ALMEIDA RAUPP

ORIENTADOR: Luiz Fernando Voss Chagas Lessa 2009.1

PONTIFÍCIA UNIVERSIDADE CATÓLICA DO RIO DE JANEIRO

RUA MARQUÊS DE SÃO VICENTE, 225 - CEP 22453-900 RIO DE JANEIRO - BRASIL 


\section{A VIDEOCONFERÊNCIA NO PROCESSO PENAL BRASILEIRO}

por

\section{THIAGO DE ALMEIDA RAUPP}

Monografia apresentada ao Departamento de Direito da Pontifícia Universidade

Católica do Rio de Janeiro (PUC-Rio) para a obtenção do Título de Bacharel em Direito.

Orientador: Luiz Fernando Voss Chagas Lessa 


\section{AGRADECIMENTOS:}

Aos meus pais, Luiz Paulo e Laura, que sempre me apoiaram em todos os momentos da minha vida e sempre me incentivaram na opção pela carreira jurídica. As minhas irmãs pelo convívio e carinho. Ao meu avô, José Vieira (in memoriam), por todas as "dicas" para o enfrentamento da vida.

A Talita, minha namorada, a qual faz todos os meus dias serem felizes, estando sempre ao meu lado, sabendo que posso contar com todo seu carinho, apoio e cumplicidade.

A todos os meus amigos, dos mais antigos, que há tempos me acompanham, até os mais recentes.

Agradeço à PUC-RIO e ao seu quadro de funcionários e professores, que tanto engrandecem e contribuem para o crescimento e reconhecido prestígio da instituição.

A Luiz Fernando, pelo aprendizado e idéias oferecidos nas aulas de direito penal, bem como pela orientação e diálogo nesse trabalho final. 


\section{RESUMO:}

Com o advento da Constituição Federal de 1988, os direitos e garantias individuais ganharam o status que sempre mereceram, sendo extensamente previstos em seu corpo. Deste modo, o vetusto Código de Processo Penal Brasileiro, datado da década de 40, necessitou de uma releitura de seus institutos e dispositivos à luz da nova Constituição e dos seus direitos e garantias individuais. Nesse ponto, inclui-se o interrogatório, verdadeiro meio de defesa do acusado submetido à persecução penal estatal. $O$ presente trabalho pretende traçar uma análise da polêmica acerca da utilização da videoconferência para a realização dos interrogatórios na seara criminal, na medida em que tal prática suscita questionamentos quanto à violação de garantias e princípios constitucionais aplicáveis ao processo penal. Inicialmente, elabora-se um breve panorama acerca dos direitos e garantias fundamentais elencados na Constituição de 1988 e sua aplicação no direito processual, partindo-se, após, para a influência apresentada no interrogatório. Após, apresenta-se os traços essenciais da recente reforma ocorrida no Código de Processo Penal e sua repercussão no interrogatório. Por fim, mostra-se a evolução da videoconferência em nosso direito, apresentando-se o debate existente, com as posições favoráveis e contrárias à tal prática, tentando demonstrar as convicções e fundamentos que justificam as duas correntes.

\section{PALAVRAS-CHAVE:}

Interrogatório no processo penal, Reforma do código de processo penal, Videoconferência, Constituição Federal de 1988, Direitos e garantias constitucionais, Princípios constitucionais. 


\section{SUMÁRIO:}

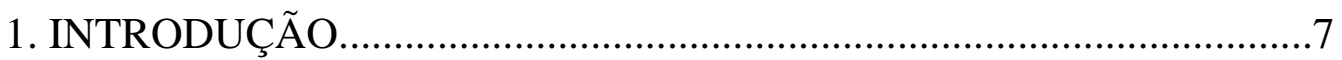

2. A CONSTITUIÇÃO FEDERAL DE 1988: PRINCÍPIOS E GARANTIAS FUDAMENTAIS.............................................................12

2.1 Direitos, garantias e princípios constitucionais.................................12

2.2. Princípios constitucionais e o processo..............................................19

2.3. Princípios constitucionais e o processo penal....................................24

3. O INTERROGATÓRIO NA SISTEMÁTICA PROCESSUAL

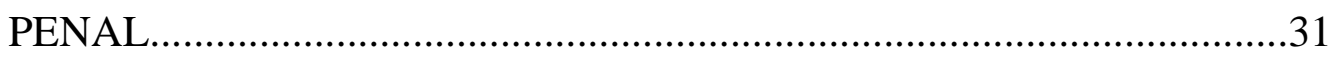

3.1. Conceituação e Características...........................................................31

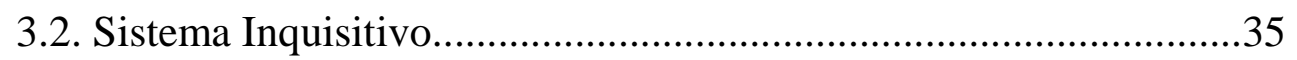

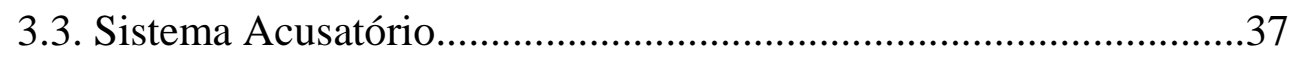

3.4. O Interrogatório e a Constituição Federal de 1988 ............................40

3.5. Direito ao Silêncio............................................................................... 41

3.6. Direito à atuação do defensor no interrogatório................................48

4. A REFORMA DA SISTEMÁTICA PROCESSUAL PENAL..................54

4.1. O Escopo da reforma do código de processo penal...................... 54

4.2. Algumas modificações da legislação processual penal...................59

4.3. O Interrogatório na nova sistemática processual penal....................62

5. O INTERROGATÓRIO POR VIDEOCONFERÊNCIA..........................71 
5.1 A utilização no direito estrangeiro................................................../ 1

5.2. A videoconferência no direito norte-americano.............................72

5.3. A videoconferência no direito italiano..........................................75

5.4. Introdução e finalidade da videoconferência no processo penal

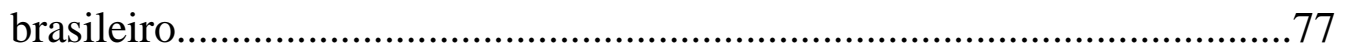

6. POSICIONAMENTOS ACERCA DA VIDEOCONFERÊNCIA........ 91

6.1. Argumentação favorável..........................................................91

6.1.1. A Questão da segurança pública.........................................92

6.1.2. A Economia proporcionada aos cofres públicos...................95

6.1.3. Celeridade processual e respeito aos direitos do acusado......98

6.2. Posicionamento contrário à videoconferência..............................104

6.2.1. A Violação aos princípios constitucionais..........................104

6.2.2. As questões da celeridade processual e da economia aos cofres

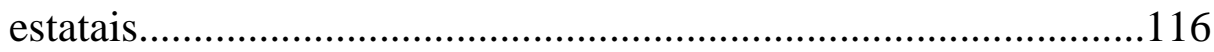

6.2.3. Breves considerações acerca da questão da segurança pública

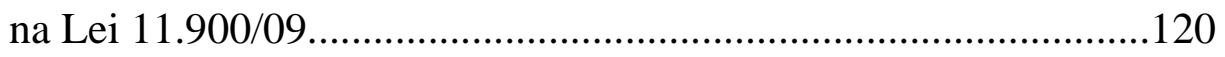

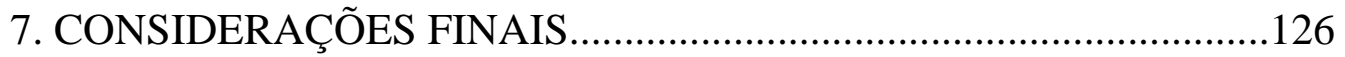

8. REFERÊNCIAS BIBLIOGRÁFICAS..........................................131 


\section{INTRODUÇÃO}

Após anos vivendo sob a égide de um regime de repressão e desrespeito pelos direitos e garantias dos cidadãos, foi promulgada a Constituição Federal de 1988, marco do processo de redemocratização em nosso país.

A nova Constituição trouxe em seu seio uma extensa previsão dos direitos fundamentais do cidadão, tratando-se, talvez, do mais amplo elenco de direitos fundamentais do constitucionalismo mundial. Além disso, o constituinte originário de 1988 preocupou-se com a efetividade de tais direitos, ressaltando a sua aplicabilidade imediata, conforme a previsão do artigo $5^{\circ}, \S$ $1^{\text {o }}$. $^{1}$

Além disso, há de se destacar a previsão de princípios fundamentais, como o do devido processo legal, da ampla defesa e do contraditório, de suma importância para o moderno direito processual, especificamente o processual penal, a fim de desenvolver um processo justo e que respeite os direitos e garantias do acusado.

Diante do reconhecimento da constituição como verdadeira norma jurídica, plenamente aplicável pelos operadores do direito, diversos institutos, das mais variadas áreas da ciência jurídica, tiveram que sofrer uma releitura, adequando-se e amoldando-se aos preceitos constitucionais.

Tal conformação mostra-se evidente no processo penal brasileiro. Nosso Código de Processo Penal, datado de 1941, nitidamente com uma feição

\footnotetext{
${ }^{1}$ SARMENTO, Daniel. Livres e Iguais - Estudos de Direito Constitucional. $1^{\text {a }}$ ed. Rio de Janeiro: Lumen Juris, 2006. p. 178.
} 
inquisitiva de processo, vem sofrendo reformas ${ }^{2}$ e novas interpretações dos seus institutos, haja vista a Constituição Federal de 1988, apesar de não expressamente assim dispor, mas dando mostra em diversos de seus dispositivos, ter consagrado o sistema acusatório como regente de toda a sistemática processual penal.

Um exemplo de um instituto que foi aperfeiçoado desde a edição da Constituição Federal de 1988, foi o interrogatório do acusado. Destaca-se, nesse ponto, as modificações implementadas pela Lei 10.792/03, a qual previu, dentre outras mudanças, a impossibilidade do silêncio do acusado ser interpretado como uma confissão, bem como não ser possível daí extrair qualquer prejuízo à sua defesa. ${ }^{3}$

De igual modo, a recente Lei 11.719, alterando os procedimentos no processo penal, modificou a posição do interrogatório do acusado, não mais sendo o primeiro ato, mas sim o último, após a inquirição das testemunhas de acusação, defesa e dos esclarecimentos de eventuais peritos, fato que só reforça o viés defensivo do interrogatório, possibilitando, de igual modo, uma análise acurada da prova, bem como "escolher a estratégia de autodefesa que melhor consulte aos seus interesses." 4

Nesse ponto, chegamos à polêmica questão do interrogatório por videoconferência no direito processual penal brasileiro e a viabilidade de sua

\footnotetext{
${ }^{2}$ Essa necessidade culminou com a formação de uma Comissão de Reforma do Código de Processo Penal, a qual já elaborou um anteprojeto, já convertido no Projeto de Lei no 156 do Senado Federal, de um novo código, totalmente reformulado e conforme as diretrizes e institutos da Constituição Federal de 1988.

${ }^{3}$ Artigo 186, § único, do Código de Processo Penal: "O silêncio, que não importará em confissão, não poderá ser interpretado em prejuízo da defesa."

${ }^{4}$ OLIVEIRA, Eugênio Pacelli de. Curso de Processo Penal. 10a ed. Rio de Janeiro: Lumen Juris, 2008. p. 326.
} 
implantação, diante dos direitos, garantias e princípios fundamentais que atuam a favor dos acusados submetidos à persecução penal estatal.

Já há previsão em nosso ordenamento, consubstanciada na Lei 11.900/09, a qual alterou o Código de Processo Penal, permitindo, de modo excepcional, tal modalidade de inquirição do acusado, desde que a decisão seja devidamente motivada e fundamentada em um dos incisos do $\S 2^{\circ}$, do artigo 185.

Não há como se negar que a medida teve uma acolhida calorosa, demonstrando uma ampla aceitação social, sustentando seus defensores que a prática gerará economia aos cofres públicos, já que não haverá mais gastos com o deslocamento dos acusado, bem como reforçará a segurança do estado, evitando fuga e possíveis resgates durante o deslocamento até à audiência. Além disso, sustenta-se que a tramitação dos feitos será mais célere que outrora.

Todavia, há uma corrente que defende a impossibilidade de tal prática, na medida em que mitiga direitos e garantias do acusado, necessários para uma defesa de qualidade e eficaz, bem como viola princípios de estatura constitucional, como, por exemplo, o do devido processo legal, da ampla defesa e do contraditório.

O presente estudo tem por objetivo analisar a viabilidade da implantação do interrogatório por videoconferência no direito processual brasileiro e em que medida viola direitos e garantias do acusado.

Inicialmente, faz-se uma breve exposição dos direitos, garantias e princípios que a Constituição Federal de 1988 consagrou em seus dispositivos, 
demonstrando a aplicação dos mesmos no direito processual de uma maneira geral, e, após, sua repercussão na seara processual penal.

Em seguida, passa-se a analisar o interrogatório do acusado, ressaltando suas características mais marcantes e seu procedimento. Além disso, apresentase sua evolução histórica, tanto no sistema inquisitivo, como no de feição acusatória, pontuando suas notas fundamentais perante esses dois modelos de processo penal. Ademais, traça-se uma análise da relação entre alguns preceitos constitucionais e sua aplicação no âmbito do interrogatório.

Posteriormente, é feita uma breve exposição das recentes reformas pelas quais o Código de Processo Penal passou, analisando seus impactos e mudanças no que tange ao interrogatório do acusado.

Após, traça-se o desenvolvimento do interrogatório por videoconferência em nossa sociedade e em nosso direito processual penal, revelando os objetivos que nortearam a adoção desse instituto em nosso direito.

Por fim, apresentado o espelho histórico do interrogatório por videoconferência em nosso direito, faz-se uma análise da corrente que sustenta a viabilidade deste modelo, bem como a que rechaça tal prática, demonstrando e analisando os argumentos de cada posição separadamente.

Observe-se que o presente estudo não visa esgotar todas as discussões e implicações que o tema faz surgir, mas tão somente trazer a tônica da discussão atual que permeia a prática, revelando a complexidade das questões que envolvem a problemática do interrogatório à distância, que repercutem não 
só no direito positivo como também nas decisões de política criminal a serem tomadas no futuro. 


\section{A CONSTITUIÇÃo FEDERAL DE 1988: PRINCíPIOS E GARANTIAS FUNDAMENTAIS}

\section{1 - Direitos, garantias e os princípios Constitucionais}

Durante longos e tormentosos anos, do período de 1964 a 1985, o Brasil assistiu a um domínio do regime militar, com a derrocada da democracia, vivenciando-se um período de supressão dos direitos e garantias básicas do cidadão, como a liberdade de expressão e de reunião pacífica.

Todavia, uma parcela da sociedade não se calou: diversos segmentos sociais combateram veementemente o regime ditatorial, cada um à sua maneira, quer fosse por meio das palavras, lançando sua revolta de modo direto em livros, publicações de jornais e letras de música, quer fosse no combate armado nas ruas país afora.

No curso do período militar, entre lutas e confrontos, foi outorgada a Constituição de 1967, vindo, tempos depois, a ser substituída pela Emenda Constitucional $n^{\mathbf{o}} 1 / 69$, a qual muitos consideram como uma nova Constituição. ${ }^{5}$

Malgrado as citadas Constituições já trouxessem em seu seio diversos dispositivos antidemocráticos e que restringiam direitos e garantias da nação

\footnotetext{
${ }^{5}$ Nesse sentido, entendendo que a Emenda Constitucional $n^{\circ}$ 1/69 deve ser tratada como uma nova Constituição, observe-se a lição de José Afonso da Silva: "Teórica e tecnicamente, não se trata de emenda, mas de nova constituição. A emenda só serviu como mecanismo de outorga, uma vez que verdadeiramente promulgou texto integralmente reformulado, a começar pela denominação que se lhe deu: Constituição da República Federativa do Brasil, enquanto a de 1967 se chamava apenas Constituição do Brasil." SILVA, José Afonso da. Curso de Direito Constitucional Positivo. $2^{\mathrm{a}}$ ed. São Paulo: Revista dos Tribunais, 1984. p. 45.
} 
brasileira, foram editados, em complementação, Atos Institucionais pelo comando militar, podendo-se afirmar que o mais agressivo desses documentos, violentando direitos, garantias, a moral e a civilidade, foi o Ato Institucional $\mathrm{n}^{\circ}$ 5, editado em 17.10.1978.

Celso Ribeiro Bastos aponta muito bem o caráter maléfico do Ato Institucional $n^{\circ} 5$ :

"o "AI-5 marca-se por um autoritarismo ímpar do ponto de vista jurídico conferindo ao Presidente da República uma quantidade de poderes que muito provavelmente poucos déspotas da história desfrutaram, tornando-se marco de um novo surto revolucionário, dando a tônica do período vivido na década subseqüente."

Diante de tantas atrocidades e condutas contrárias à democracia, grande parcela da população clamava por uma mudança na ordem política e constitucional do país, que trouxesse novamente à tona o respeito pelos valores e direitos dos cidadãos, construindo-se um país livre, sob a égide de um verdadeiro Estado Democrático de Direito.

O reencontro com a democracia e os direitos somente ocorreu, de forma plena, com a promulgação da Constituição da República Federativa do Brasil de 1988, fruto de um árduo desenvolvimento e discussão pela Assembléia Nacional Constituinte, e apelidada de "Constituição Cidadã, tendo em vista a ampla participação popular durante a sua elaboração e a constante busca de efetivação da cidadania.",

A Constituição de 1988 representou uma virada de página em nossa história, deixando para trás o autoritarismo e hostilidade da ditadura, tornandose um marco de uma época de esperança num futuro melhor, fundado numa

\footnotetext{
${ }^{6}$ BASTOS, Celso Ribeiro. Curso de Direito Constitucional. $18^{\mathrm{a}}$ ed, São Paulo: Saraiva, 1997. p.136.

${ }^{7}$ LENZA, Pedro. Direito Constitucional Esquematizado. $12{ }^{\text {a }}$ ed, São Paulo: Saraiva, 2008. p. 58.
} 
sociedade livre, justa, igualitária e democrática, conforme se depreende da leitura do seu preâmbulo.

Luís Roberto Barroso, em comentários à Constituição de 1988, ressalta sua importância simbólica para a sociedade brasileira da época:

"A Constituição Brasileira de 1988 tem, antes e acima de tudo, um valor simbólico: foi ela o ponto culminante do processo de restauração do Estado democrático de direito e da superação de uma perspectiva autoritária, onisciente e não pluralista de exercício do poder, timbrada na intolerância e na violência." ${ }^{8}$

Ponto de maior relevo em nossa Constituição é a atenção que confere aos direitos e garantias fundamentais do cidadão, no Título II, principalmente em seu artigo $5^{\circ}$, que traz extenso rol acerca da matéria e assim preceitua em seu caput:

"Art. $5^{\circ}$ - Todos são iguais perante a lei, sem distinção de qualquer natureza, garantindo-se aos brasileiros e aos estrangeiros residentes no país a inviolabilidade do direito à vida, à liberdade, à igualdade, à segurança e à propriedade, nos termos seguintes:".

Resta evidente, da leitura do referido artigo e dos seus incisos, a intenção do constituinte em pontuar individualmente cada um dos direitos, detalhando-os, buscando ampará-los constitucionalmente com maior abrangência possível. Tal fato ensejou aplausos da doutrina e a afirmação de que a Constituição de 1988 “alargou significativamente o campo dos direitos e garantias fundamentais, colocando-se entre as constituições mais avançadas do mundo no que diz respeito à matéria". 9

\footnotetext{
${ }^{8}$ BARROSO, Luís Roberto. Temas de Direito Constitucional. $1^{\text {a }}$ ed. Rio de Janeiro: Renovar, 2001. p.10.

${ }^{9}$ PIOVESAN, Flávia. Direitos Humanos e o Direito Constitucional Internacional. 8 a ed. São Paulo: Saraiva, 2007. p. 25.
} 
Da análise do citado artigo, infere-se a busca pelo respeito às liberdades religiosas, de pensamento, de ir e vir, o direito de reunião pacífica, o acesso à justiça por todos os cidadãos, bem como os direitos e garantias pertinentes aos que são partes em um processo judicial ou administrativo.

Além disso, colimou-se defender a igualdade entre todos os cidadãos, a fim de evitar discriminações de qualquer gênero ou espécie, bem como os direitos à intimidade, à privacidade, à integridade corporal e à propriedade.

O mencionado artigo da Constituição se refere a direitos e garantias, tratando-os, pois, como expressões distintas, como na verdade o são. A fim de melhor definir suas áreas de atuação, Rui Barbosa, à sua época, no final do século XIX, realizou conhecida distinção entre os direitos e as garantias, concluindo que existem

"as disposições meramente declaratórias, que são as que imprimem existência legal aos direitos reconhecidos, e as disposições assecuratórias, que são as que, em defesa dos direitos, limitam o poder. Aquelas instituem os direitos, estas as garantias; ocorrendo não raro juntar-se, na mesma disposição constitucional, ou legal, a fixação da garantia, com a declaração de direito". ${ }^{10}$

Assim, pode-se afirmar que, tendo em vista a lição de Rui Barbosa, as garantias elencadas no texto constitucional viabilizam o exercício dos direitos, bem como os protegem de qualquer interferência ilegal e arbitrária, praticada tanto pelo poder público, quanto por um particular.

Tamanho plexo de direitos e garantias têm como objetivo limitar a atuação estatal, que deverá sempre respeitar a órbita individual de cada

\footnotetext{
10 BARBOSA, Rui. República: Teoria e Prática (Textos doutrinários sobre direitos humanos $e$ políticos consagrados na primeira Constituição da República). Petrópolis/Brasília, 1978, p.121 e 124, apud DA SILVA, José Afonso. Curso de Direito Constitucional Positivo. $2^{\mathrm{a}}$ ed. São Paulo. Revista dos Tribunais, 1984. p. 292.
} 
cidadão, regendo a relação particular x estado, protegendo-os contra qualquer arbítrio ou decisão que não se coadune com os preceitos da Constituição da República de $1988 .^{11}$

Além dessa faceta de defesa em face do estado, os direitos e garantias fundamentais também exigem uma atuação positiva do estado, que também deve pautar sua atuação na proteção e promoção dos mesmos. ${ }^{12}$

Muitos dos direitos e garantias tratados no citado artigo foram erigidos à categoria de princípios, devido a sua grande importância e repercussão nas relações sociais, de observância obrigatória por todos os operadores do direito, como, por exemplo, o Princípio do Devido Processo Legal (5º LV) e da Inafastabilidade do Poder Judiciário (5, XXXV).

É possível definir princípios como sendo o conjunto das idéias fundamentais que constituem o arcabouço do ordenamento jurídico; são os valores básicos da sociedade que se constituem em princípios jurídicos. ${ }^{13}$

Nas palavras de Ronald Dworkin, os princípios são dotados de grande carga axiológica e moral, definindo-os o autor americano como sendo um:

\footnotetext{
11 Importante ressaltar que, hodiernamente, muito se discute acerca da aplicação desses direitos e garantias fundamentais no âmbito das relações privadas. Trata-se da denominada "eficácia horizontal dos direitos fundamentais". Acerca do tema, veja-se a lição de Fredie Didier: "Desse modo, a atual Constituição brasileira, pela "moldura axiológica" em que se encontra estampada (de índole eminentemente intervencionista e social), admite a ampla vinculação dos particulares aos direitos fundamentais nela erigidos, de modo que não só o Estado como toda sociedade podem ser sujeitos passivos desses direitos”. DIDIER, Fredie. Curso de Direito Processual Civil, vl.1. 9a ed. Bahia: JusPODIVM, 2008. p.31.

${ }^{12}$ SARMENTO, Daniel. Livres e Iguais - Estudos de Direito Constitucional. $1^{\text {a }}$ ed. Rio de Janeiro: Lumen Juris, 2006. p. 178.

${ }^{13}$ GRANDINETTI. O Processo Penal em Face da Constituição - Princípios Constitucionais do Processo Penal. $2^{\text {a }}$ ed. Rio de Janeiro: Lumen Juris, 1998. p 5.
} 
"standard que deve ser observado, não porque favoreça ou assegure uma situação econômica política ou social considerada desejável, mas porque é uma exigência da justiça, da equidade ou de alguma outra dimensão da moralidade." 14

Apesar da grande importância que a doutrina moderna lhes confere, antes da promulgação de nossa Carta Política os princípios eram reconhecidos somente por sua função de integrar o ordenamento jurídico, quando não fosse possível recorrer à analogia e aos costumes gerais de direito.

Hodiernamente, com o amplo reconhecimento de que a Constituição de 1988 é uma verdadeira norma jurídica, os princípios e, de igual modo, os direitos e garantias fundamentais, são vistos sob uma nova ótica, adquirindo uma característica de alto relevo: possuem aplicabilidade imediata.

E tal fato só foi possível com a consagração das Constituições como verdadeiras normas jurídicas, possibilitando que as suas disposições fossem aplicadas diretamente pelos juízes. Daniel Sarmento relata-nos como era a situação da Constituição antes de adquirir o status de norma jurídica:

\begin{abstract}
"Afirmar que a Constituição é norma jurídica parece uma obviedade desnecessária. Mas nem sempre foi assim. Descontada a singular exceção norte-americana, a idéia que prevalecia no "mundo constitucionalizado" até meados do século XX era a de que as constituições eram proclamações políticas importantes, mas não autênticas normas jurídicas. As prescrições constitucionais não podiam ser aplicadas diretamente pelos juízes, nem geravam direitos subjetivos para os cidadãos. Só as leis editadas pelos parlamentos obrigavam e vinculavam: não as solenes e abstratas determinações constitucionais. " 15
\end{abstract}

O autor destaca a passagem do Estado Liberal para o Estado Social e a ocorrência de eventos traumatizantes para a história da humanidade, como, por

\footnotetext{
${ }^{14}$ PEREIRA, Jane Reis Gonçalves; SILVA, Fernanda Duarte Lopes Lucas da. A Estrutura Normativa das Normas Constitucionais. Notas sobre a Distinção entre Princípios e Regras. In: GUERRA, Isabella Franco; PEIXINHO, Manoel Messias (Org.). Os Princípios da Constituição de 1988. $2^{\mathrm{a}}$ ed. Rio de Janeiro: Lumen Juris, 2006. p.3-21.

${ }_{15}$ SARMENTO, Daniel. Livres e Iguais - Estudos de Direito Constitucional. $1^{\text {a }}$ ed. Rio de Janeiro: Lumen Juris, 2006. p. 170.
} 
exemplo, o Holocausto, como causas dessa nova visão da Constituição, a qual surge como um mecanismo de controle dos abusos estatais e, concomitantemente, mitigando a idéia de que às leis podia ser atribuído qualquer conteúdo, desde que ditado por autoridades competentes para tanto. ${ }^{16}$

Diante de tal quadro histórico, adquirindo a Constituição tal força, iniciou-se no mundo contemporâneo e especialmente no Brasil, uma irradiação das normas constitucionais nos diversos ramos do direito, regendo a interpretação e aplicação do direito infraconstitucional:

"Um fenômeno relativamente recente no país tem provocado uma profunda alteração em todos os ramos do direito: a constitucionalização do ordenamento jurídico. É praticamente impossível encontrar hoje um processo judicial em qualquer área - civil, penal, trabalhista, etc. - em que a Constituição não seja em algum momento invocada pelas partes do litígio e depois empregada pelo juiz ou tribunal na fundamentação da decisão (....). A Constituição tornou-se ubíqua." ${ }^{\prime \prime}$

E dentre as principais normas constitucionais que foram irradiadas para os diversos ramos do direito, os princípios constitucionais, sem dúvida alguma, merecem destaque.

Diante dessa dimensão de valores de justiça e eqüidade que possuem intrinsecamente, os princípios se infiltraram em larga escala pelos diversos ramos de nosso direito, sendo utilizados, hodiernamente, como parâmetros para a interpretação das leis e dos códigos, convivendo com os princípios específicos de cada seara do direito.

Assim, conclui-se que nossa Constituição possui direitos, garantias e princípios, voltados a todos os cidadãos, na intenção de desenvolver uma

\footnotetext{
${ }^{16}$ Ibid. p. $173-174$

${ }^{17}$ Ibid. p. 167
} 
sociedade mais justa, mais igual, livre de opressões e desmandos e fundada na observância das leis e respeito às instituições democráticas.

\section{2 - Princípios constitucionais e o processo}

Tempos atrás, os conflitos existentes entre indivíduos eram solucionados pelos próprios, não havendo regras pré-estabelecidas para a discussão e solução pacífica e eficiente do problema, gerando muitas vezes embates violentos entre os cidadãos, cada qual querendo fazer prevalecer sua vontade. Era a denominada autotutela (ou autodefesa). ${ }^{18}$

Nítido que essa não era a melhor forma de solução de controvérsias, diante da instabilidade e insegurança que tal método se revestia, razão pela qual o Estado, gradativamente ao longo da história, imiscui-se nessa tarefa, conforme lição de Luiz Rodrigues Wambier:

"Somente muito tempo depois, com o desenvolvimento da noção de Estado e, conseqüentemente, com o nascimento das primeiras idéias a respeito daquilo que seria, mais tarde, o Estado de Direito, é que a tarefa de solucionar os conflitos (por conflito entenda-se aquela "parcela" deste levada ao judiciário, ou seja, a lide) entre as pessoas foi admitida como função do estado (...)". ${ }^{19}$

Nasce, a partir desse ponto, a função jurisdicional acometida ao Estado, o qual deverá se pronunciar diante das discussões e controvérsias trazidas pelos particulares, ou mesmo órgãos estatais, em uma verdadeira substituição da

\footnotetext{
${ }^{18}$ GRINOVER, Ada Pelegrini et al. Teoria Geral do Processo. $21^{\mathrm{a}}$ ed. São Paulo: Malheiros, 2005. p. 23.

${ }^{19}$ WAMBIER, Luiz Rodrigues. Curso Avançado de Processo Civil, vl.1. $7^{\text {a }}$ ed. São Paulo: Revista dos Tribunais, 2005. p.42.
} 
vontade das partes $^{20}$, aplicando ao caso a solução mais justa e acorde com o direito vigente, buscando pacificar o ambiente social. ${ }^{21}$

Todavia, a aplicação das regras insertas na legislação ao caso concreto, função esta efetuada pela jurisdição, deverá ser exercida mediante um processo prévio, funcionando este, portanto, como verdadeiro instrumento viabilizador da atuação estatal, garantindo-se às partes todos os direitos e garantias que norteiam o processo moderno.

Conforme lição de José Frederico Marques, o processo, como atividade intelectiva do juiz, se apresenta como a "série de atos coordenados regulados pelo direito processual, através dos quais se leva a cabo o exercício da jurisdição". 22

Assentada a conceituação de processo, passa-se a uma breve análise da sua relação com os princípios constitucionais que o regem e norteiam.

Como visto no item anterior, as normas constitucionais, especificamente os princípios, irradiaram-se por todo o ordenamento, servindo como base de releitura dos diversos ramos do direito e parâmetro de interpretação, ganhando grande destaque na seara processual.

O denominado neoconstitucionalismo, como não podia deixar de ocorrer, influenciou fortemente o direito processual, que voltou a ser estudado

\footnotetext{
${ }^{20}$ É o que Chiovenda denomina de "substitutividade", uma das características mais marcantes da jurisdição para o autor, conforme elucida Fredie Didier. DIDIER, Fredie. Curso de Direito Processual Civil. 19a ed. Bahia: JusPODIVM, 2008. p.66.

${ }^{21}$ Moacyr Amaral Santos, em comentários acerca do objetivo da jurisdição, afirma que "sua finalidade é manter a paz jurídica". Primeiras Linhas de Direito Processual Civil, v. I. $23^{\mathrm{a}}$ ed, São Paulo: Saraiva, 2004. p. 70.

${ }^{22}$ MARQUES, José Frederico. Instituições de Direito Processual Civil, v. I. ed. 1958. p. 14. apud JÚNIOR, Humberto Theodoro. Curso de Direito Processual Civil, v. I, 44 a ed. Rio de Janeiro: Forense, 2006. p.49.
} 
sob uma perspectiva constitucional, sendo influenciado pelos princípios da Carta Magna, já existindo parte da doutrina que denomina tal fenômeno de "neoprocessualismo". 23

Malgrado o direito processual possua princípios próprios, desvinculados da sistemática constitucional, é inegável que os princípios de maior importância e utilização prática são os que a Constituição consagra.

Alexandre Câmara, atento a tal fato, leciona exatamente nesse sentido:

"Como qualquer outra ciência, também o direito processual está sujeito a princípios norteadores de todo o desenvolvimento da disciplina. Tais princípios servem de orientação segura para a interpretação dos institutos que integram o campo de atuação da ciência, sendo certo que os mais importantes princípios processuais encontram-se consagrados na Constituição da República." ${ }^{24}$

A Constituição da República, especialmente em seu artigo 5, o qual consagra direitos e garantias fundamentais do cidadão, traz um leque extenso de princípios constitucionais aplicáveis ao processo.

Rogério Cruz e Tucci enumera as regras mais importantes do citado artigo, pertinentes à temática processual, quais sejam: a) acessibilidade econômica e técnica à justiça; b) juiz natural; c) tratamento paritário dos sujeitos parciais do processo; d) plenitude da defesa, com todos os meios a ela inerentes, especialmente no tocante ao direito de ser informado, à bilateralidade da audiência (contraditoriedade) e ao direito à prova legitimamente obtida ou produzida; e) publicidade, desde o aforamento da ação

\footnotetext{
${ }^{23}$ DIDIER, Fredie. Curso de Direito Processual Civil. vl.1. $9^{\mathrm{a}}$ ed. Bahia: JusPODIVM, 2008. p. 28.

${ }^{24}$ CAMÂRA, Alexandre. Lições de Direito Processual Civil. v. I. $16^{\mathrm{a}}$ ed. Rio de Janeiro: Lumen Juris, 2007. p. 33.
} 
da parte, ou da acusação, até o proferimento de sentença, necessariamente motivada. $^{25}$

Diante da influência das normas constitucionais sobre o desenvolvimento do direito processual, a doutrina afirma que a Constituição é fonte formal das normas processuais, refletindo-se, muitas vezes, dada a posição das regras que contém no plano das fontes formais do direito, no próprio conflito de interesses objeto do processo. ${ }^{26}$

Afirma-se, além disso, que as normas processuais são um complemento ou atualidade das garantias constitucionais, daí porque, inseridas na Lei das Leis, visam, certamente a reforçar o sistema de direitos e garantias do cidadão. $^{27}$

Portanto, hodiernamente, qualquer processo, quer seja no âmbito, cível, penal, tributário, deverá se guiar pelas normas constitucionais, que lhe darão a direção e conferirão aos litigantes um processo pautado na justiça e com todos os direitos e garantias que estão à sua disposição.

Tal assertiva é confirmada na prática forense atual, onde expressiva parte das petições, arrazoados, ou defesas, direta ou indiretamente, sustentam teses amparadas em princípios constitucionais, invocando a força normativa dos mesmos, o mesmo ocorrendo nos fundamentos das decisões dos magistrados.

\footnotetext{
${ }^{25}$ CRUZ E TUCCI, José Rogério. Constituição de 1988 e Processo. Regramentos e garantias constitucionais do processo. $1^{\mathrm{a}}$ ed. São Paulo: Saraiva, 1989, p. 5.

26 Ibid. p. 1.

27 Ibid. p. 2.
} 
Por fim, cabe ressaltar que os princípios inseridos na Constituição cumprem papel importante não só à interpretação e à aplicação do direito, mas, também, auxiliam na busca da efetividade do processo.

Com o objetivo de demonstrar a idéia do que se concebe por efetividade do processo, recorre-se a lição do mestre José Carlos Barbosa Moreira, o qual resume a questão em cinco pontos principais: a) o processo deve dispor de instrumentos de tutela adequados a todos os direitos; b) esses instrumentos devem ser praticamente utilizáveis, sejam quais forem os supostos titulares dos direitos: c) é preciso assegurar condições propícias à exata e completa reconstituição dos fatos relevantes, a fim de que o convencimento do julgador corresponda à realidade: d) o resultado do processo deve assegurar à parte vitoriosa o pleno gozo da utilidade específica a que faz jus segundo o ordenamento: e) esses resultados hão de ser atingidos com o mínimo dispêndio de tempo e energia. ${ }^{28}$

Na esteira da idéia de uma efetividade cada vez maior do processo, por exemplo, está o princípio da razoável duração do processo, fruto da assinatura da República Brasileira ao Pacto de São José da Costa Rica, e recentemente inserido no artigo $5^{\circ}$, inciso LXXVIII, consagrando o direito a uma prestação num tempo razoável, sem delongas desnecessárias, objetivando que as partes tenham suas pretensões atendidas de forma célere e objetiva.

Note-se que tal princípio atua para garantir uma celeridade ao processo, sem nenhuma perda de qualidade da instrução, atendendo à idéia do ponto da

\footnotetext{
${ }^{28}$ MOREIRA, José Carlos Barbosa. Notas sobre o problema da "efetividade" do processo. In Temas de Direito Processual. Terceira Série. São Paulo: Saraiva, 1984. p 27-42 apud GRINOVER, Ada Pellegrini. Teoria Geral do Processo. In O Processo em Evolução. $2^{\mathrm{a}}$ Ed. Rio de Janeiro: Forense, 1998. p. 3-29.
} 
letra "e" supracitado, objetivando que as partes tenham suas pretensões acolhidas em tempo razoável.

Apresentada a relação umbilical do direito processual com os princípios constitucionais, passa-se a uma análise específica do assunto no Direito Processual Penal, ramo com diversas peculiaridades, haja vista lidar com um dos bens mais caros a todo ser humano: a liberdade.

\section{3 - Princípios constitucionais e o processo penal}

A concepção inicial do nosso Código de Processo Penal apenas como instrumento de processo e punição do réu, dando-se prevalência ao interesse público na apuração e punição dos culpados, com a aplicação fria das regras de direito para se chegar à pena, não mais prospera na vigente ordem constitucional. $^{29}$

A promulgação da Constituição de 1988 trouxe novas luzes à interpretação e à aplicação do Código de Processo Penal, as quais devem se guiar pelos princípios e garantias que a nova carta trouxe, alterando, com isso, a feição do processo penal pátrio.

Hodiernamente, diante da Constituição de 1988, o processo penal é um verdadeiro instrumento de defesa e garantias dos direitos do acusado submetido a uma persecução penal, que tem a seu favor diversos princípios que objetivam formar um processo penal justo e equânime, sem abusos e

${ }^{29}$ OLIVEIRA, Eugênio Pacelli de. Curso de Processo Penal. 10 a ed. Rio de Janeiro: Lumen Juris, 2008. p. 5-10. 
autoritarismos por parte do Estado, sendo certo que "sob certo aspecto o processo penal representa mais uma forma de auto-limitação do estado do que um instrumento destinado à persecução criminal.",30

Haja vista trazer diversas garantias e direitos fundamentais aplicáveis à persecução penal, pode-se afirmar que a Constituição se preocupou com a estruturação do processo penal, concluindo Geraldo Prado, acerca dessa relação Processo/Constituição, que “o Direito Constitucional e o Direito Processual Penal são legatários de uma vocação comum." „31

Tomando alguns dos princípios constitucionais aplicáveis ao processo penal e estruturando-o, é possível afirmar que este deverá sempre se pautar pela busca da igualdade efetiva entre os litigantes, já que o réu possui uma posição original de desvantagem, observando-se o contraditório e a ampla defesa, sempre com o auxílio técnico de um advogado, devendo, ainda, todas as decisões serem tomadas por um juiz com competência pré-definida ao fato delituoso e de forma fundamentada. Por fim, devem ser excluídas quaisquer prova obtidas ilicitamente, já que a sua aceitação violaria princípios $\left(5^{\circ}, \mathrm{LVI}\right)$ e direitos individuais. ${ }^{32}$

Tendo em vista os princípios citados anteriormente, resta claro que estão intimamente ligados, caminhando em direção à uma mesma finalidade: a necessidade de o Estado, na persecução penal, observar as garantias e os direitos do acusado, na conformidade de um processo isento e justo. Luis Gustavo Grandinetti, atento a tal fato, leciona neste sentido:

\footnotetext{
${ }^{30}$ JARDIM, Afrânio Silva. Ação Penal Pública - Princípio da Obrigatoriedade. $1^{\mathrm{a}}$ ed. Rio de Janeiro: Forense, 1988. p.16.

31 PRADO, Geraldo. Sistema Acusatório. A Conformidade Constitucional das Leis Processuais Penais. Rio de Janeiro: Lumen Juris, 1999. p. 66-68.

32 OLIVEIRA, Eugênio Pacelli de. Curso de Processo Penal. 10 a ed. Rio de Janeiro: Lumen Juris, 2008. p. 8.
} 
"Os princípios Constitucionais que encerrem garantias processuais estão intimamente interligados entre si, de sorte que se pode tornar difícil estabelecer que princípio é responsável por qual garantia processual. Na verdade, essa interligação quer significar que esses princípios conformam um todo, um conjunto, uma idéia fundamental assumida pelo legislador constituinte e que está abrigada na Constituição em mais de um dispositivo, em mais de uma oportunidade. Essa idéia fundamental pode ser extraída da preocupação da Constituição em estabelecer um processo legal e justo." 33

Diante de sua grande importância, alguns princípios constitucionais deverão ser sempre observados no âmbito do processo penal, em defesa de sua justiça, conforme magistério de Eugênio Pacelli:

"Em relação ao processo penal enquanto sistema jurídico de aplicação do Direito Penal, estruturado em sólidas bases constitucionais, pode-se adiantar a existência de alguns princípios absolutamente inafastáveis, $e$, por isso, fundamentais, destinados a cumprir a árdua missão de proteção e tutela dos direitos individuais." ${ }^{34}$

Apesar da importância que todos os princípios supracitados possuem, a doutrina e a jurisprudência dão tratamento ímpar e destacado ao princípio do devido processo legal ( $\left.5^{\circ}, \mathrm{LIV}\right)$, que regeria toda a sistemática processual, sendo ressaltado, freqüentemente, que seria a fonte originária da maioria dos princípios constitucionais, que dele derivariam direta ou indiretamente.

Referido princípio deita raízes na Carta Magna de 1215, imposta pelos barões feudais ao rei João Sem Terra, e a qual buscava limitar o absolutismo.

Conforme Carlos Roberto Siqueira Castro, embora inicialmente se pretendesse tão somente a limitação dos poderes reais exercidos por João SemTerra, sem qualquer alusão a um devido processo legal como hoje conhecemos, o instituto estava "fadado a tornar-se a suprema garantia das

\footnotetext{
${ }^{33}$ GRANDINETTI, Luis Gustavo. O Processo Penal em Face da Constituição - Princípios Constitucionais do Processo Penal. $2^{\text {a }}$ ed. Rio de Janeiro. Lumen Juris, 1998, p. 5.

${ }^{34}$ OLIVEIRA, Eugênio Pacelli de. Curso de Processo Penal. 10 a ed. Rio de Janeiro: Lumen Juris, 2008. p. 27.
} 
liberdades fundamentais do indivíduo e da coletividade em face do poder público". 35

Dessa idéia embrionária, desenvolveu-se o Princípio do Devido Processo Legal, plenamente aplicável ao processo penal, colimando assegurar um processo justo para o acusado, no qual ele possa exercer todas as faculdades e direitos que lhe competem, de maneira ampla e eficaz.

Dessa concepção, extrai-se a idéia de que tal princípio consagra a garantia da participação do réu no processo, podendo exercer manifestações que contrariem a tese acusatória formulada pelo órgão estatal, atuando, de tal e qual modo, que permita-lhe influenciar na decisão final do magistrado acerca do caso. ${ }^{36}$

Essa estrutura, apresentada anteriormente, denomina-se dialética do processo, e consubstancia-se na apresentação de uma tese pelo órgão acusatório, a refutação desta pelo acusado (antítese), e a síntese final, que seria a decisão do juiz.

Há, como demonstrado nessa estrutura dialética, uma grande participação dos sujeitos no processo, trazendo argumentos e elementos de convicção ao magistrado, em efetiva participação, emergindo dessa atuação cooperativa, a garantia de imparcialidade do magistrado, o qual só se manifestará com a sua decisão ao final da apresentação dos argumentos e teses das partes. ${ }^{37}$

\footnotetext{
${ }^{35}$ CASTRO, Carlos Roberto Siqueira. O Devido Processo Legal e os Princípios da Razoabilidade e da Proporcionalidade. $3^{\mathrm{a}}$ ed. Rio de Janeiro: Forense, 2005. p. 5.

36 GRINOVER, Ada Pelegrini. Novas Tendências do Direito Processual de Acordo com a Constituição de 1988. Forense Universitária, 1990, p. 3.

${ }^{37}$ Ibid. p. 3.
} 
Ainda na esteira do devido processo legal, pode-se deduzir que daí emerge a concepção da efetiva participação das partes no processo, consubstanciada no Princípio do Contraditório, idéia defendida pela doutrina de Ada Pellegrini Grinover:

"Esse efetivo contraditório, afirma a Constituição, deve ser observado na atividade
instrutória. Com o adequado conhecimento, primeiro, que possibilite a organização
de todas as atividades defensivas a serem efetivamente desempenhadas no processo,
por intermédio do segundo momento - a participação (...). Mas a participação na
instrução há de ser entendida em seu verdadeiro sentido, que não se limita à
atividade probatória, estendendo-se a tudo quanto sirva para preparar o espírito do
juiz." 38

Além disso, as regras legais pré-estabelecidas deverão ser observadas rigorosamente, evitando-se qualquer surpresa para o réu, que, de antemão, já deverá conhecer todo o procedimento legal que será adotado, evitando-se favoritismos de qualquer sorte ou mesmo abusos por parte do estado, que não poderá escolher a esmo as regras e o procedimento que adotará em cada caso para a punição do réu. ${ }^{39}$

Todavia, a doutrina afirma que tal princípio não se limita a circunscrever todas essa garantias em âmbito estritamente processual, tão somente, dando-lhe, também, uma feição substancial. Afirma-se, assim, a necessidade de um processo legislativo de elaboração de lei previamente definido e regular, bem como razoabilidade e senso de justiça de seus dispositivos, necessariamente enquadrados nas preceituações constitucionais. ${ }^{40}$

Aprofundando a idéia do aspecto substantivo do Princípio do Devido Processo Legal, Luis Gustavo Grandinetti leciona que tal princípio toma

\footnotetext{
${ }^{38}$ Ibid. p. $10-11$.

${ }^{39}$ Daí se infere que o Devido Processo Legal abarca tanto o Princípio do Juiz Natural, quanto o que veda a instituição de tribunal de exceção.

${ }^{40}$ FERNANDES, Antônio Scarance. Processo Penal Constitucional. $3^{a}$ ed. São Paulo: Revista dos Tribunais, 2002. p. 42.
} 
função especial no processo penal, sendo sua aplicação pautada na busca da razoabilidade no processo:

"Quanto ao aspecto substantivo do devido processo legal, é possível ao aplicador da lei aferir se a imposição de qualquer medida coativa processual penal atende ao que reclama a razoabilidade ou a racionalidade, ou, em outros termos, se a medida processual é proporcional, ou seja, se é legal, teleologicamente justificável, necessária, idônea e preencha os demais requisitos de motivação e judicialidade. "41

Com isso, busca-se afirmar que, além das previsões legais que estatuam garantias e direitos ao acusado, consubstanciando o viés material/formal do princípio, há também a faceta substancial, sendo necessário que as normas contenham preceitos razoáveis e proporcionais, devendo os aplicadores do direito aplicá-las, também, de maneira razoável, equilibrada, a fím de não despontar em autoritarismos ou violações de direitos do acusado.

Em conclusão, é seguro afirmar que o Princípio do Devido Processo Legal objetiva salvaguardar o próprio processo, em sua acepção objetiva, como fator legitimante do exercício da jurisdição. ${ }^{42}$

Da exposição acerca do conteúdo de tal princípio, inferem-se características que originaram diversos outros princípios constitucionais. Daí se afirmar que se trata de "um postulado fundamental do direito constitucional, do qual derivam todos os outros princípios." 43

Diante dos princípios citados anteriormente, resta claro a íntima relação existente entre o direito processual penal e o direito constitucional, haja vista

\footnotetext{
${ }^{41}$ GRANDINETTI, Luis Gustavo. O Processo Penal em Face da Constituição - Princípios Constitucionais do Processo Penal. $2^{\mathrm{a}}$ ed. Rio de Janeiro. Lumen Juris, 1998, p. 76.

${ }^{42}$ GRINOVER, Ada Pelegrini. Teoria Geral do Processo. $21^{\mathrm{a}}$ ed. São Paulo: Malheiros, 2005. p. 84.

${ }^{43}$ JÚNIOR, Nelson Nery. Código de Processo Civil Comentado e Legislação Extravagante. 7 a ed. São Paulo: Revista dos Tribunais, 2003. p.130.
} 
este estabelecer e enunciar os princípios que se desenvolverão e terão efetiva atuação no processo penal. 


\section{O INTERROGATÓRIO NA SISTEMÁTICA PROCESSUAL PENAL}

\section{1 - Conceito e características}

Como visto no capítulo anterior, as leis, em sua grande maioria, devem ser aplicadas por intermédio do processo, servindo este como um instrumento da jurisdição. Essa concepção é, de igual modo, aplicada no âmbito do Direito Penal e Processual Penal.

A sanção penal não pode ser aplicada de imediato, no instante em que o delito é cometido, sendo necessário o processo para se alcançar tal objetivo, devendo ser comprovada a autoria, a materialidade e a culpabilidade do agente, o qual tem pleno direito de defesa durante toda a instrução criminal, em atendimento aos princípios constitucionais do devido processo legal, do contraditório e da ampla defesa.

O processo, sendo uma atividade complexa, é composto por vários atos, formando um procedimento lógico e harmônico, a fim de desembocar no provimento final do magistrado. Dentre tais atos, insere-se o interrogatório do acusado, regulado nos artigos 185 a 196 do Código de Processo Penal.

Em linhas gerais, pode-se definir o ato do interrogatório, consoante a lição de Fernando da Costa Tourinho, como o "o meio pelo qual o Juiz ouve 
do pretenso culpado esclarecimentos sobre a imputação que lhe é feita e, ao mesmo tempo, colhe dados importantes para o seu convencimento. ${ }^{\prime 44}$

Trata-se do momento processual em que o réu poderá expor e esclarecer os fatos como eles se deram na prática, fornecendo a sua versão pessoal dos mesmos, podendo o juiz realizar perguntas que entender pertinentes para o seu maior convencimento, sendo, em igual medida, facultado ao advogado de defesa e ao órgão do Ministério Público formular questões ao acusado.

Trata-se, em regra, de um ato público, podendo qualquer um comparecer no dia e hora marcados para o interrogatório do acusado, gozando este da liberdade e garantia de que não se praticará nenhuma coação ou extorsão buscando confissões suas.

Ressalte-se que a regra da publicidade do interrogatório pode sofrer restrições, sendo conferido ao juiz realizá-lo a portas fechadas, com limitação do número dos presentes, nos casos de tal ato ser suscetível de resultar escândalo, inconveniente grave ou perturbação da ordem, tudo conforme o disposto no artigo $792, \S 1^{\circ}$, do Código de Processo Penal. ${ }^{45}$

Pense-se, por exemplo, em um caso de grande comoção nacional, noticiado exaustivamente pela mídia e que atraia um sem número de repórteres e populares ao Fórum, o que, sem dúvida, prejudicaria o bom andamento dos trabalhos em audiência, justificando a restrição da publicidade do ato.

\footnotetext{
${ }^{44}$ FILHO, Fernando da Costa Tourinho. Processo Penal, v. 3, $27^{\mathrm{a}}$ ed. São Paulo: Saraiva, 2005. p. 269. ${ }^{45}$ O Pacto de São José da Costa Rica, incorporado ao direito brasileiro pelo Decreto ${ }^{\circ} 678$ de 06 de novembro de 1992, prevê semelhante disposição em seu artigo $8^{\circ}, 5$., o qual trata das garantias judiciais da pessoa submetida a um processo: "O processo penal deve ser público, salvo quando for necessário pra preservar os interesses da justiça".
} 
Além da publicidade, o interrogatório detém a característica de ser um ato personalíssimo, devido ao fato de que só o acusado pode ser interrogado, não se admitindo qualquer tipo de representação para tal fim, substituição ou sucessão processual. $^{46}$

Outra característica importante é a oralidade. É de suma importância poder o juiz analisar a figura do acusado, seus gestos, palavras, tom de voz, espontaneidade, a fim de buscar elementos mais concretos de convicção, necessidade esta que, nas palavras de Hélio Tornaghi, é “insubstituível por uma declaração escrita, morta, gélida, despida dos elementos de valor psicológico que acompanham a declaração falada."

Portanto, esse contato com o juiz por meio da palavra, e também toda essa gesticulação corporal, se mostram imperiosas para o desenvolvimento de uma boa defesa, já que permitirá ao magistrado observar as emoções do acusado, o modo como relata os fatos, sendo a via mais eficaz de se aferir a veracidade dos fatos.

Pontuadas essas características mais essenciais, é importante apontar a estrutura do interrogatório e como se desenvolve na prática tal ato. Conforme o artigo 187 do Código de Processo Penal, o interrogatório é dividido em duas etapas: pessoa do acusado e fatos.

$\mathrm{Na}$ primeira parte, disposta no artigo $187, \S 1^{\circ}$, as perguntas são direcionadas à pessoa do acusado, não sendo relacionadas à infração penal. Objetiva-se a obtenção de informações pessoais que possam ser úteis ao

\footnotetext{
${ }^{46}$ MIRABETE, Júlio Fabbrini. Processo Penal. $2^{\text {a }}$ ed. São Paulo: Atlas S.A., 1992. p. 268.

${ }^{47}$ TORNAGHI, Hélio. Curso de Processo Penal, v. I. São Paulo: Saraiva, 1980. p. 364.
} 
processo, à discussão da causa e à formação da convicção do juiz, bem como, na hipótese de condenação, à individualização da pena. ${ }^{48}$

Inquiri-se o acusado acerca de sua residência, meios de vida ou profissão, oportunidades sociais, lugar onde exerce a sua atividade, vida pregressa, notadamente se foi preso ou processado alguma vez, bem como outros dados familiares e sociais.

Ato contínuo, na segunda parte do interrogatório, disposta no artigo $187, \S 2^{\circ}$, serão formulados questionamentos sobre a procedência da acusação, a infração penal e as provas relacionadas, bem como outras perguntas que possam contribuir para a elucidação da verdade, podendo exercer o interrogando sua autodefesa. ${ }^{49}$

Por fim, dispõe o artigo 196, do Código de Processo Penal, que “A todo tempo o juiz poderá proceder a novo interrogatório de ofício ou a pedido fundamentado de qualquer das partes".

Tal previsão reconhece a suma importância do interrogatório para fins de defesa do acusado, podendo as partes ou o juiz requerer a realização de nova inquirição, quando, por exemplo, restarem fatos ou pontos controvertidos a serem melhor elucidados.

\footnotetext{
48 Importante ressaltar que a individualização da pena é um princípio aplicável ao Direito Penal, disposto no artigo $5^{\circ}$, inciso XLVI da Constituição Federal, do qual se extrai a necessidade da individualização e a personalização das sanções, atendendo a características do agente e às circunstâncias que rodearam o crime cometido, sendo tal princípio observado do momento da elaboração legislativa dos tipos penais, passando pela aplicação da pena, até a execução final desta. Giuseppe Bettiol, lecionando acerca do tema, afirma que "todo o direito penal moderno é orientado no sentido da individualização das medidas penais, porquanto se pretende que o tratamento penal seja totalmente voltado para características pessoais do agente a fim de que possa corresponder aos fins que se pretende alcançar com a pena ou com as medidas de segurança". Apud GRECO, Rogério. Curso de Direito Penal. Parte Geral. v I. Niterói, Rio de Janeiro: Impetus, 2008. p. 71.

${ }^{49}$ MIRABETE, Júlio Fabbrini. Processo Penal. $2^{\mathrm{a}}$ ed. São Paulo: Atlas S.A, 1992. p. 270/271.
} 
Desta forma, referido dispositivo coaduna-se com os princípios da Carta Magna atinentes à defesa, aduzindo Marcellus Polastri Lima que "assegura-se, assim, maior amplitude da ampla defesa e do contraditório, dogmas constitucionais". 50

Assentada as linhas gerais do interrogatório e suas características principais, passa-se a analisar como se dava tal ato historicamente, analisandoo nas perspectivas dos sistemas inquisitivo e acusatório, principais sistemas do processo penal ao longo da história.

\section{2 - Sistema Inquisitivo}

O processo penal do tipo inquisitivo deita raízes em Roma, mas foi realmente difundido na idade média pelo Direito Canônico, e, por influência da igreja, o processo per inquisitionem, utilizado na repressão às infrações dos hereges, se alastrou por grande parte da Europa Continental. ${ }^{51}$

Uma das características mais marcantes desse sistema processual era o fato das funções de acusação, defesa e julgamento concentrarem-se nas mãos de uma pessoa somente: o juiz. Este iniciava o processo ex officio, sem nenhuma acusação previamente formulada contra o indivíduo, fato que levava à parcialidade do julgador, o que obstava análises justas dos casos que lhe eram submetidos.

\footnotetext{
${ }^{50}$ LIMA, Marcellus Polastri. Curso de Processo Penal, v. III. $2^{\mathrm{a}}$ ed. Rio de Janeiro: Lumen Juris, 2006. p. 123.

${ }^{51}$ TORNAGHI, Hélio. Curso de Processo Penal, v. I. São Paulo: Saraiva, 1980. p. 15.
} 
O juiz, por ter a iniciativa probatória contra o réu, funcionava como um verdadeiro gestor das provas, atuando com um “juiz ator”, característica marcante do sistema inquisitivo. ${ }^{52}$

Além disso, o sistema inquisitivo consagrava o processo escrito, sigiloso em sua forma e conteúdo, não havendo contraditório por parte do acusado, estando este totalmente indefeso perante a acusação que pairava contra si, o que gerava grave desequilíbrio de forças no julgamento.

Admitia-se, outrossim, denúncias apócrifas como válidas a ensejar a abertura de processo, o qual iniciava-se de ofício por parte do magistrado. ${ }^{53}$

O interrogatório era verdadeiro meio de prova do juízo, a fim de que este corroborasse suas acusações, sendo o acusado ouvido sem defensor ao seu lado, sem nenhuma garantia de defesa, e, conforme preleciona Fernando da Costa Tourinho, a prática da tortura era ato comum:

"O interrogatório do acusado era precedido ou seguido de torturas. Regulamentouse a tortura: "deve cessar quando o imputado expresse a vontade de confessar. Se confessa durante os tormentos e, para que a confissão seja válida, deve ser confirmada no dia seguinte." 54

Buscava-se, com isso, a denominada "rainha das provas", qual seja, a confissão do acusado, a prova máxima do sistema inquisitivo, e que detinha

\footnotetext{
52 JÚNIOR, Aury Lopes. Propostas para um Novo Modelo de Persecução Criminal - Combate à Impunidade. Disponível em < http://www.cjf.jus.br/revista/SerieCadernos/Vol25/tema03.pdf.>.

${ }^{53}$ Ressalte-se que a jurisprudência do Supremo Tribunal Federal rechaça o início da persecução penal baseada única e exclusivamente na apresentação de uma denúncia anônima, ressaltando, todavia, que a autoridade policial pode, com "prudência e discrição", verificar a informação que the foi fornecida, viabilizando, desse modo a futura persecução penal, conforme assenta o Ministro Celso de Mello, em seu voto na Questão de Ordem referente ao Inquérito ${ }^{\circ} 1957$. STF, Questão de Ordem no Inquérito $n^{\circ}$ 1.957, Rel. Ministro Carlos Velloso, Brasília, 11 de mai. 2005.

${ }^{54}$ FILHO, Fernando da Costa Tourinho. Processo Penal, v. 1. $29^{\mathrm{a}}$ ed. São Paulo: Saraiva, 2007. p. $84 / 85$.
} 
valor absoluto em face das outras, sendo o indivíduo, portanto, um verdadeiro objeto de prova do processo.

Importante ressaltar que, como a ampla defesa e o contraditório lhe eram vedados, não era possível a convocação de testemunhas de defesa, a fim de corroborarem a versão dos fatos fornecida em seu interrogatório.

Não havia, como visto, direito ao silêncio no interrogatório, devendo o réu falar ou confessar o delito, sob pena de sofrer graves torturas, o que só vem a demonstrar os inconvenientes do interrogatório realizado sob o manto do sistema inquisitivo.

Devido à finalidade eminentemente probatória do interrogatório, no qual o juiz acusador buscaria mais subsídios para a condenação, conjugado com a inexistência de direito à defesa nesse ato secreto, podendo ser o réu alvo até de tortura, só realmente a intervenção Deus para defender o réu. ${ }^{55}$

\section{3 - Sistema Acusatório}

Diante dos abusos e injustiças conduzidos pelo sistema inquisitivo, iniciou-se, por volta do século XVIII, um movimento de combate contra tal sistema, voltando à tona o sistema acusatório, outrora utilizado nos primórdios da Grécia e em Roma, até ser substituído pelo inquisitivo, anteriormente visto.

\footnotetext{
55 A alusão a essa intervenção divina como única forma de defesa do réu no processo inquisitivo deriva do brocardo da idade média segundo o qual "aquele que tem um juiz por acusador, precisa de Deus como defensor. E, às vezes, isso não é suficiente”. In PRADO, Geraldo. Sistema Acusatório. A Conformidade Constitucional das Leis Processuais Penais. Rio de Janeiro: Lumen Juris, 1999, p.157.
} 
Uma das principais características desse sistema, consoante Eugênio Pacelli, é a da separação das funções de acusar, defender e julgar, as quais estão dispostas entre diferentes sujeitos, cada qual as exercendo pessoalmente, extinguindo-se a concentração de funções e poderes nas mãos do magistrado. ${ }^{56}$

O processo, agora, é público, sendo fiscalizável pelo povo; o juiz não detém mais o poder de iniciar o processo de ofício, cabendo a acusação a um órgão acusador próprio; o acusado pode defender-se e exercer seu direito ao contraditório a fim de comprovar sua inocência. ${ }^{57}$

O interrogatório deixa de ser um ato secreto, e, por isso, acaba-se com a tortura do acusado, meio cruel que era utilizado no sistema inquisitivo para obter a confissão.

Cesare Beccaria, em seu clássico trabalho intitulado Dos Delitos e das Penas, escrito no século XVIII, já condenava e propugnava pelo fim da tortura no interrogatório, que, além de ser cruel e degradante ao ser humano, não significava, necessariamente, o encontro da verdade dos fatos:

"Fazem interrogatório a um acusado para conhecer a verdade; porém, se com tanta dificuldade a distinguem no ar, nos gestos e na fisionomia de um homem calmo, como poderão descobri-la nos traços decompostos pelas convulsões da dor, quando todos os sinais, que apontam às vezes a verdade na fronte dos culpados, estiverem alterados e confundidos?"58

Desloca-se o réu, portanto, da posição de mero objeto do processo, passando a ser sujeito deste, exercendo seus direitos e garantias atinentes à

\footnotetext{
${ }^{56}$ OLIVEIRA, Eugênio Pacelli de. Curso de Processo Penal. 10 a ed. Rio de Janeiro: Lumen Juris, 2008. p. 8.

${ }^{57}$ FILHO, Fernando da Costa Tourinho. Processo Penal, v 1. $29^{\mathrm{a}}$ ed. São Paulo: Saraiva, 2007. $29^{\mathrm{a}}$ ed. p. 90.

${ }_{58}^{5}$ BECCARIA, Cesare. Dos Delitos e das Penas. $1^{\mathrm{a}}$ ed. São Paulo: Rideel, 2003. p. 45.
} 
defesa e ao contraditório, restando-se seguro contra qualquer ameaça de tortura durante seu interrogatório.

Ademais, essa divisão bem pontuada das partes no processo, não mais acumulando o juiz a acusação, defesa e julgamento em suas mãos, é importante na consolidação da imparcialidade do juiz que interrogará o acusado. Acaba-se com a figura do "juiz ator" que inicia o processo sem qualquer provocação e busca provas para a condenação do acusado, num acúmulo indevido de funções.

Geraldo Prado traça lição exatamente acerca desse ponto:

"Assim, se na estrutura inquisitória o juiz "acusa", na acusatória a existência de parte autônoma, encarregada da tarefa de acusar, funciona para deslocar o juiz para o centro do processo, cuidando de preservar a nota de imparcialidade que deve marcar sua atuação". ${ }^{59}$

Portanto, é importante perceber que o sistema acusatório está ligado à defesa dos direitos do acusado durante todo o procedimento, livrando-o dos arbítrios estatais outrora concebidos no sistema inquisitivo.

Desse modo, proporciona-se um interrogatório mais justo e humano para o acusado, o qual não será compelido a confessar o que às vezes não fez, ou que, mesmo tendo feito, não quer revelar, podendo prestar suas declarações de forma calma e desimpedida, exercendo sua defesa do modo que melhor lhe aprouver.

Em conclusão acerca do tema, recorre-se novamente à lição de Geraldo Prado:

\footnotetext{
59 PRADO, Geraldo. Sistema Acusatório. A Conformidade Constitucional das Leis Processuais Penais. Rio de Janeiro: Lumen Juris, 1999. p.106.
} 
"Com efeito, como assinala Cordero - e também James Goldschmidt - "as regras do jogo" distinguem o processo acusatório do inquisitório. Este último se satisfaz com o resultado obtido de qualquer modo, pois nele prevalece o objetivo de realizar o direito penal material, enquanto no processo acusatório é a defesa dos direitos fundamentais do acusado contra a possibilidade de arbítrio do poder de punir que define o horizonte do mencionado processo". ${ }^{60}$

Como se observa, o sistema acusatório guarda preocupação em relação às garantias do acusado e a possibilidade de exercê-las de modo pleno e eficaz, consubstancio-se em uma defesa de qualidade e passível de influir no resultado final do julgamento da causa.

\section{4 - O Interrogatório e a Constituição Federal de 1988}

Com o advento da Constituição Federal de 1988, o Processo Penal deixa para trás muitas das características inquisitoriais e autoritárias que nortearam sua promulgação, devendo seus institutos receberem uma interpretação à luz dos direitos, garantias e princípios inseridos na nova carta, aplicando-os a toda a disciplina processual. ${ }^{61}$

É possível afirmar que a Constituição Federal de 1988 consagrou o sistema acusatório como modelo de persecução penal, fato este constatado em inúmeros dispositivos, dentre os quais se destacam os artigos 129, inciso I, incumbindo privativamente ao Ministério Público a promoção da ação penal pública; o artigo $5^{\circ}$, inciso $\mathrm{LV}$, consagrando o direito ao contraditório e à ampla defesa; o art. $5^{\circ}$, inciso LVII, o qual traz a presunção de não

\footnotetext{
${ }^{60}$ PRADO, Geraldo. Sistema Acusatório. A Conformidade Constitucional das Leis Processuais Penais. Rio de Janeiro. Lumen Juris, 1999, pp.104.

${ }^{61}$ Cabe observar que, muito embora a Constituição de 1988 exija um novo olhar e uma nova interpretação dos temas processuais penais, o Código de Processo Penal, quando da promulgação da Carta Magna, não sofreu nenhuma alteração formal imediata em seus dispositivos a fim de adequá-los à nova ordem constitucional.
} 
culpabilidade até o trânsito em julgado da sentença condenatória, bem como a previsão do artigo 93, inciso IX, prevendo a regra da publicidade nos julgamentos realizados pelo Poder Judiciário.

Todavia, apesar dos inúmeros dispositivos constitucionais que consagram o sistema acusatório, nosso Código de Processo Penal, editado no ano de 1941, em plena Era Vargas, ainda traz diversos resquícios de inquisitorialidade em seu seio, o que traz dificuldades em classificarmos nosso sistema processual como um acusatório puro.

Desta constatação, advém a crítica de Guilherme de Souza Nucci:

"É certo que muitos processualistas sustentam que o nosso sistema é o acusatório. Mas baseiam-se exclusivamente nos princípios constitucionais vigentes (contraditório, separação entre acusação e órgão julgador, publicidade, ampla defesa, presunção de inocência etc.). Entretanto, olvida-se, nessa análise, o disposto no Código de Processo Penal, que prevê a colheita inicial da prova através do inquérito policial, presidido por um bacharel em Direito, que é o delegado, com todos os requisitos do sistema inquisitivo (sigilo, ausência de contraditório e ampla defesa, procedimento eminentemente escrito, impossibilidade de recusa do condutor da investigação etc.) Somente após, ingressa-se com a ação penal e, em juízo, passam a vigorar as garantias constitucionais mencionadas, aproximando-se o procedimento do sistema acusatório.(...)"62.

Feita essa breve observação acerca do sistema acusatório insculpido na Constituição, passa-se a analisar as garantias constitucionais que devem ser observadas no interrogatório do acusado.

Todas as garantias constitucionais favoráveis ao acusado possuem aplicabilidade direta em seu interrogatório, permitindo uma defesa adequada neste ato processual, de modo a sempre dispor de um advogado que o auxilie, sendo inquirido por um juiz imparcial, o qual centralizará suas atenções no

62 NUCCI, Guilherme de Souza. Manual de Processo Penal e Execução Penal. $3^{\text {a }}$ ed. São Paulo: Editora Revista dos Tribunais, 2007. p. 104-105. 
julgamento do feito e não participará da acusação, tarefa essa incumbida privativamente ao Ministério Público, conforme o art. 129, I, da Constituição Federal. Além disso, caso entenda conveniente, pode manter-se calado, exercendo seu direito ao silêncio.

Tais direito e garantias só vem a corroborar a idéia, já há muito difundida, de que o interrogatório judicial é legítimo meio de defesa do réu, a fim de influir na decisão final do magistrado.

Reconhecendo tal fato, aduz Fernando da Costa Tourinho:

"Se o acusado pode calar-se, ficando o juiz obrigado a respeitar-lhe o silêncio, erigido à categoria de direito fundamental, não se pode dizer seja o interrogatório um meio de prova... Fosse o interrogatório meio de prova, a Lei de Imprensa o exigiria também. Entretanto, ali se diz que o réu será interrogado "se o requerer". Se se trata de meio de prova, a Lei Eleitoral não o teria dispensado, como realmente o dispensou durante mais de trinta anos....Se fosse meio de prova, o CPP, no artigo 188, não impediria a intervenção das partes. Na verdade, se a instrução criminal é contraditória, e sendo ela integrada pelo interrogatório, afrontaria a Lei Maior a não-intervenção das parte" ${ }^{, 63}$

Na mesma linha, entende o Ministro Celso de Mello, do Supremo Tribunal Federal, que o interrogatório é um meio de defesa, como se observa do seguinte julgado:

"Em sede de persecução penal, o interrogatório judicial - notadamente após o advento da Lei 10.792/03 - qualifica-se como ato de defesa do réu, que, além de não ser obrigado a responder a qualquer indagação feita pelo magistrado processante, também, não pode sofrer qualquer restrição em sua esfera jurídica em virtude do exercício, sempre legítimo, dessa potencial prerrogativa. Doutrina. Precedentes. ${ }^{, 64}$

\footnotetext{
${ }^{63}$ TOURINHO FILHO, Fernando da Costa. Processo Penal, v.III. $27^{\mathrm{a}}$ ed. São Paulo: Saraiva, 2005. p. 271.

${ }^{64}$ STF, Rel. Ministro Celso de Mello, Habeas Corpus no 94.016-1, Brasília, Julgamento 16 set. 2008. Observe-se que no presente Habeas Corpus, o Supremo Tribunal Federal, reconhecendo o interrogatório como meio de defesa, reconheceu a possibilidade dos acusados, em um mesmo processo, formularem perguntas uns aos outros, como corolário do princípio constitucional da ampla defesa.
} 
Todavia, apesar de seu nítido caráter defensivo, o interrogatório possuiria também um viés de meio de prova, já que o acusado, ao prestar declarações ao juízo, fornece-lhe elementos que podem servir à apuração da verdade. Deste modo, expressiva parte da doutrina considera o interrogatório como tendo natureza mista. ${ }^{65}$

Feitas essa observações, passa-se a analisar, de modo individual, algumas das garantias incidentes no interrogatório do acusado, advindas diretamente da ordem constitucional de 1988 e que consubstanciam tal ato como meio de defesa do réu.

\section{5 - Direito ao Silêncio}

O direito ao silêncio está consagrado no artigo $5^{\circ}$, inciso LXIII da Constituição Federal e no artigo 186 do Código de Processo Penal, bem como disposto no artigo 8 2 .g, da Convenção Americana sobre Direitos Humanos, o Pacto de São José da Costa Rica, integrado em nosso ordenamento jurídico por via do Decreto ${ }^{\circ}$ 678, de 06 de novembro de 1992.

Tal direito proporciona ao acusado a opção pelo silêncio durante seu interrogatório, não sendo obrigado a responder as perguntas que lhe são formuladas, bem como garantindo que não será obrigado a produzir provas

\footnotetext{
${ }^{65} \mathrm{Na}$ defesa dessa corrente, aduz Mirabete que "quando o acusado se defende no interrogatório, não deixa de apresentar ao julgador elementos que podem ser utilizados na apuração da verdade, seja pelo confronto com provas existentes, seja por circunstâncias e particularidades das próprias informações prestadas. Mesmo o silêncio do acusado, que não importa em confissão e não pode ser interpretado em prejuízo do réu, pode contribuir, na análise das provas já existentes ou que vierem a ser produzidas, para a formação da convicção íntima do juiz. Conceitualmente, portanto, o interrogatório é meio de prova e oportunamente de defesa do acusado. Tem, portanto, esse caráter misto afirmado pela doutrina dominante”. MIRABETE, Júlio Fabbrini. Processo Penal. $2^{\mathrm{a}}$ ed. São Paulo: Atlas S.A, 1992. p. 266.
} 
contra si mesmo. Essa dupla faceta foi muito bem definida por Eugênio Pacelli:

"Atingindo duramente um dos grandes pilares do processo penal antigo, qual seja, o dogma da verdade real, o direito ao silêncio e à não auto-incriminação não só permite que o acusado ou aprisionado permaneça em silêncio durante toda a investigação e mesmo em juízo, como impede que ele seja compelido a produzir ou a contribuir com a formação da prova contrária ao seu interesse. "66

Deste modo, é certo afirmar que o direito ao silêncio extrai-se da assertiva de que ninguém é obrigado a produzir provas contra si mesmo, assertiva esta consagrada no brocardo nemu tenetur se detegere, que significa, literalmente, ninguém é obrigado a se descobrir. ${ }^{67}$

Tal idéia de proibição da produção de provas contra si mesmo implica na concepção de que o imputado não é obrigado a concorrer, ativa ou passivamente, no curso da investigação ou do processo, na colheita de provas aptas a demonstrar que ele de fato praticou a infração penal de que é acusado. ${ }^{68}$

Sendo assim, permite-se ao réu avaliar da conveniência e oportunidade de prestar declarações em juízo, já que pode entender que as mesmas podem

${ }^{66}$ OLIVEIRA, Eugênio Pacelli de. Curso de Processo Penal. $10^{\mathrm{a}}$ ed. Rio de Janeiro: Lumen Juris, 2008. p. 30.

${ }^{67}$ TOVIL, Joel. A Proteção contra a auto-acusação compulsória aplicada à persecução penal. In: LIMA, Marcellus Polastri (Org.), MORAES, Bruno Ribeiro (Org.). Estudos Criminais em Homenagem a Weber Martins Batista. Rio de Janeiro: Lumen Júris, 2008. p. 245-278.

${ }^{68}$ Ibid. p. 245-278. Pode-se exemplificar com a possibilidade do investigado recusar-se a participar da reconstituição do crime. Ressalte-se a discordância de José Barcelos de Souza, citada por Joel Tovil, acerca da amplitude conferida ao direito ao silêncio, disposto no Pacto de São José da Costa, no artigo $8^{\circ}, 2$. g, e do qual, segundo tal autor, a doutrina extrai a idéia de que ninguém é obrigado a produzir provas contra si mesmo: "a regra contida no pacto consagra simplesmente o direito da pessoa "de não ser obrigada a depor contra si mesma, nem declarar-se culpada". Quer dizer, também aí a proteção diz respeito precipuamente a declarações verbais (...) o Direito de permanecer calado só é agasalhado pela Constituição naquele aspecto de direito ao silêncio, que foi e é uma necessidade para coibir uma tendência de arrancar confissões, que se extorquiam até de inocentes. Prejudicar a obtenção de provas, porém sem ferir direitos fundamentais, só servirá para favorecer a impunidade". 
prejudicá-lo de alguma forma, influindo negativamente na percepção do magistrado e do órgão do Ministério Público acerca do caso, tendo, portanto, conseqüências nefastas para sua defesa.

Além disso, como o interrogatório é verdadeiro meio de defesa, não há a obrigatoriedade do acusado sustentar esta ou aquela versão para os fatos, estando, deste modo, descompromissado com o dever processual de verdade. ${ }^{69}$

Não se trata, como aduz Júlio Fabbrini Mirabete, de um “verdadeiro direito de mentir", já que as contradições em seu depoimento podem ensejar a perda da credibilidade das suas declarações. O que ocorre, na realidade, é que, pelo fato de não prestar compromisso de dizer a verdade frente ao juízo, como o faz, em regra, a testemunha, sua mentira não constitui crime. Portanto, o réu é livre para mentir, pois se o fizer nenhuma sanção lhe será imposta. Logicamente, como tal liberalidade é conferida tão somente a favor de sua defesa, caso atribua a si ou a outrem crime inexistente, cometerá o crime de auto-acusação falsa, disposto no artigo 342, do Código Penal. ${ }^{70}$

Cabe ressaltar que o direito ao silêncio e não auto-acusação restringe-se à segunda parte do interrogatório, momento em que o acusado responde acerca dos fatos e do mérito da imputação. Deve, assim, responder a toda a primeira parte, que trata da sua qualificação pessoal e de questões que lhe são próprias.

Acerca dessa limitação do direito ao silêncio na primeira parte do interrogatório, esclarece a professora Ada Pellegrini Grinover:

"As perguntas sobre a qualificação do acusado não estão acobertadas pelo direito ao silêncio, porquanto em sua resposta não se caracteriza qualquer atividade

\footnotetext{
${ }^{69}$ OLIVEIRA, Eugênio Pacelli de. Curso de Processo Penal. 10 a ed. Rio de Janeiro: Lumen Juris, 2008. p. 330.

70 MIRABETE, Júlio Fabbrini. Processo Penal. $2^{\mathrm{a}}$ ed. São Paulo: Atlas S.A, 1992. p. 270.
} 
defensiva. O artigo 187 e seus parágrafos do CPP, na redação dada pela 10.792/03, traçam bem essa distinção, assentando que o interrogatório será constituído de duas partes: sobre a pessoa do acusado e sobre os fatos. ${ }^{71}$

Além disso, como bem observa Maria Elisabeth Queijo, a necessidade da correta identificação do acusado nessa primeira parte do interrogatório é elemento importante para a adequada persecução penal, evitando inclusive que os dados de terceiros seja fornecidos indevidamente pelo acusado. ${ }^{72}$

Diante da consagração ao direito ao silêncio e a não auto-incriminação, o Código de Processo Penal se amoldou à sistemática acusatória instituída pela Constituição de 1988, alterando, por via da lei 10.792/03, o artigo 186, § único, dispondo também que o silêncio não poderá ser interpretado em prejuízo da defesa e muito menos importará em confissão de qualquer fato.

Cabe lembrar que antes da referida alteração, tal artigo revestia-se de características nitidamente inquisitivas, sendo possível o silêncio do acusado ser interpretado em desfavor da defesa, como se depreendia da leitura da redação anterior:

"Antes de iniciar o interrogatório, o Juiz observará ao réu que, embora não esteja obrigado a responder às perguntas que lhe forem formuladas, o seu silêncio poderá ser interpretado em prejuízo da própria defesa”.

De suma importância, portanto, a mudança no artigo 186, pois, do contrário, de nada valeria o direito ao silêncio caso o magistrado ou o órgão do Ministério Público pudessem extrair ilações indevidas do silêncio do réu, no

\footnotetext{
${ }^{71}$ GRINOVER, Ada Pellegrini et al. As Nulidades no Processo Penal. São Paulo: RT, $8^{\mathrm{a}}$ ed. 2004, p. 97.

72 TOVIL, Joel. A Proteção contra a auto-acusação compulsória aplicada à persecução penal. In: LIMA, Marcellus Polastri (Org.), MORAES, Bruno Ribeiro (Org.). Estudos Criminais em Homenagem a Weber Martins Batista. Rio de Janeiro: Lumen Júris, 2008. p. 245-278.
} 
sentido de que se nada fala é por que esconde algo, sendo, por dedução equivocada, culpado. ${ }^{73}$

\section{6 - Direito à atuação do defensor no interrogatório}

A necessidade da presença e participação efetiva do defensor no ato do interrogatório do acusado decorre das previsões constitucionais do art. $5^{\circ}$, incisos LV e LXIII, respectivamente:

"Art. 50. Todos são iguais perante a lei, sem distinção de qualquer natureza, garantindo-se aos brasileiros e aos estrangeiros, residentes no país a inviolabilidade do direito à vida, à liberdade, à igualdade, à segurança e á propriedade, nos termos seguintes:

LV - Aos litigantes em processo judicial ou administrativo, e aos acusados em geral são assegurados o contraditório e ampla defesa, com os meios e recursos a ela inerentes.

LXIII - O preso será informado de seus direitos, entre os quais o de permanecer calado sendo-lhe assegurada a assistência da família e de advogado."

Observe-se que a necessidade de o réu possuir um advogado que o acompanhe ao longo de todo o processo, a denominada defesa técnica, é resultado da garantia da ampla defesa conferida pela Constituição Federal, pois, do contrário, tal preceito constitucional não seria efetivamente observado. Lecionando acerca dessa relação, Antônio Scarance Fernandes aduz que:

\footnotetext{
73 Tendo em vista tal disposição, o artigo 198 do Código de Processo Penal, o qual dispõe que "o silêncio do acusado não importa confissão, mas poderá constituir elemento de formação do convencimento do juiz“, encontra-se implicitamente revogado, conforme anota Ada Pellegrini Grinover, haja vista a impossibilidade do silêncio prejudicar o réu. GRINOVER, Ada Pellegrini et al. As Nulidades no Processo Penal. São Paulo: RT, 8 a ed. 2004, p.72.
} 
"Quando, nas Constituições, se assegura a ampla defesa, entende-se que, para observância desse comando, deve a proteção derivada da cláusula constitucional abranger o direito à defesa técnica durante todo o processo e o direito de autodefesa. Colocam-se ambos em relação de diversidade e completariedade. ${ }^{74}$

Além disso, deve-se atentar que a outra parte na relação processual é composta pelo Ministério Público, o qual conta, para auxiliá-lo, com a Polícia Judiciária e com outras autoridades administrativas, a quem por Lei sejam cometidas as mesmas funções, conforme disposto no artigo $4^{\circ}, \S$ único, do Código de Processo Penal. Diante de tal fato, é imprescindível estar o acusado amparado também por profissional habilitado, tendo como efeito o equilíbrio entre acusação e defesa, garantindo-se, assim, a denominada paridade de armas. $^{75}$

Tendo em vista essa inafastabilidade do defensor técnico, ainda que o réu recuse e requeira que não seja acompanhado de defesa técnica, tal pleito, em nenhuma hipótese, será atendido. Isso se deve ao fato de a nossa ordem constitucional e processual penal vedar o processo e julgamento sem a presença do defensor, conforme expresso no artigo 261 do Código de Processo Penal:

Art. 261 - "Nenhum acusado, ainda que ausente ou foragido, será processado ou julgado sem defensor".

Portanto, de modo a se ajustar à sistemática constitucional ora acima explicitada, respeitando os direitos e garantias do acusado de possuir um defensor ao seu lado no interrogatório, bem como da possibilidade de atuação

\footnotetext{
${ }^{74}$ FERNANDES, Antônio Scarance. Processo Penal Constitucional. $3^{\text {a }}$ ed. São Paulo: Revista dos Tribunais, 2002. p. 270.

75 Ibid. 270-271. Júlio Fabbrini Mirabete observa que a necessidade da defesa técnica também decorre do fato de faltar capacidade para o exercício do jus postulandi (capacidade postulatória) à parte (acusado). MIRABETE, Júlio Fabbrini. Processo Penal. 2a ed. São Paulo: Atlas S.A, 1992. p. 323.
} 
efetiva deste, o Código de Processo Penal prevê em seu artigo 185, caput e $\S$ $5^{\circ}$, bem como no artigo 188 , a consagração de tais preceitos:

Art. 185 - O acusado que comparecer perante a autoridade judiciária, no curso do processo penal, será qualificado e interrogado na presença do seu defensor, constituído ou nomeado.

$\S 5^{o}$ - Em qualquer modalidade de interrogatório, o juiz garantirá ao réu o direito de entrevista prévia e reservada com o seu defensor; se realizado por videoconferência, fica também garantido o acesso a canais telefônicos reservados para comunicação entre o defensor que esteja no presídio e o advogado presente na sala de audiência do Fórum, e entre este e o preso. (redação alterada pela Lei 11.900/09)

Art. 188 - Após proceder ao interrogatório, o juiz indagará das partes se restou algum fato para ser esclarecido, formulando as perguntas correspondentes se o entender pertinente e relevante.

Como se depreende da leitura do artigo 185 , caput e do seu $\S 5^{\circ}$, o réu tem o direito de ser interrogado na presença de seu advogado, bem como de, antes de tal ato processual, consultar-se com ele, a fim de receber orientações de como se portar e responder às perguntas, "a fim de que se faça a interação da autodefesa e a defesa técnica", ${ }^{76}$

Atentando para o fato da garantia de entrevista prévia com o advogado se afigurar como uma extensão da defesa do acusado, Marcellus Polastri Lima assevera que "A medida é mais do que justificável, em vista do princípio constitucional da ampla defesa, sendo certo que o Estatuto da OAB já assegurava tal direito ao advogado, no seu art. $7^{\circ}$, III." 77

Observe-se que a presença do advogado também inibe qualquer tentativa de coação do juiz no curso do interrogatório, com ameaças ou forçando uma confissão, zelando pela regularidade de tal ato, a fim de que

\footnotetext{
${ }^{76}$ GRINOVER, Ada Pellegrini. As Nulidade no Processo Penal. ed. Revista dos Tribunais. 6 a ed, São Paulo.p. 83.

${ }^{77}$ LIMA, Marcellus Polastri. Curso de Processo Penal, v. III. $2^{\text {a }}$ ed. Rio de Janeiro: Lumen Juris, 2006. p. 115.
} 
ocorra em consonância com os ditames da lei, preservando-se todos os direitos que o acusado tem ao seu dispor.

Além disso, a entrevista prévia e a presença do advogado no interrogatório atuam no psicológico do acusado, passando tranqüilidade e segurança ao réu para responder aos questionamentos do juiz, sem temer sua figura, podendo relatar sua versão dos fatos de modo coerente, exercendo sua autodefesa de modo eficaz.

De outro giro, temos a possibilidade do defensor e do Ministério Público formular perguntas, conforme o artigo 188, do Código de Processo Penal.

Cabe observar, inicialmente, que antes da atual disposição do artigo 188, trazida pela Lei 10.792/03, o interrogatório era um ato privativo do juiz, possuindo um caráter eminentemente judicial, de modo que tal concepção impedia às partes, Ministério Público e defesa, intervirem ou realizarem perguntas durante o seu curso. ${ }^{78}$

Ora, de que vale uma defesa técnica constituída se esta não pode manifestar-se na audiência, formulando perguntas ao réu? Esse impedimento, é nítido perceber, não estava em consonância com a ampla defesa que a Constituição assegura ao acusado.

Deve-se ter em vista que a exigência da defesa técnica não se perfaz por inteiro com a mera constituição formal de um advogado, devendo este possuir todos os meios e instrumentos para concretizar uma defesa eficaz e de qualidade.

\footnotetext{
${ }^{78}$ Ibid. p. 118.
} 
Antônio Scarance Fernandes leciona acerca de tal necessidade:

"O fato de ter o réu defensor constituído, ou de ter sido nomeado advogado para sua defesa, não é suficiente. É preciso que se perceba, no processo, atividade efetiva do advogado no sentido de assistir o acusado. De que adiantaria defensor designado que não arrolasse testemunhas, não reperguntasse, oferecesse alegações finais exageradamente sucintas, sem análise da prova, e que, por exemplo, culminasse com pedido de Justiça? Haveria, aí, alguém designado para defender o acusado, mas a sua atuação seria tão deficiente que é como se não houvesse defensor. ${ }^{79}$

E arremata o autor lecionando que "a defesa deve ser efetiva, não sendo suficiente a aparência de defesa”. ${ }^{80}$

Portanto, é imperativo que o advogado possa formular indagações ao réu, a fim de que sua participação tenha importância e efetividade, auxiliando na defesa e, sobretudo, contribuindo com o fornecimento de mais elementos para a convicção do juiz, o que, por certo, irá influenciá-lo na decisão final.

Referida contribuição não se destina tão somente a figura do juiz, mas também é direcionada para o órgão do Ministério Público, o qual poderá se convencer da verossimilhança e credibilidade das respostas do réu, pugnando por sua absolvição em sede de alegações finais, entendendo-o inocente. $\mathrm{O}$ mesmo raciocínio se aplica ao Tribunal do Júri, onde os jurados possuiriam mais informações e subsídios para a tomada da decisão final.

Observe-se que a defesa técnica poderá colmatar lacunas deixadas pelo magistrado em sua oitiva, bem como pelo órgão do parquet, indagando o réu, por intermédio do juiz, acerca de fatos ainda não levantados, esclarecendo-se,

\footnotetext{
${ }^{79}$ FERNANDES, Antônio Scarance. Processo Penal Constitucional. $3^{\text {a }}$ ed. São Paulo: Revista dos Tribunais, 2002. p. 273-274.

${ }^{80}$ Ibid. p. 273.
} 
com isso, de maneira mais completa e precisa, na medida do possível, os fatos como eles se deram na prática.

Por fim, diante da necessidade inafastável da defesa técnica durante o curso do processo penal, sobremaneira no ato do interrogatório, de suma importância, a Constituição Federal garante aos menos abastados, que não tem como contratar um advogado particular, auxílio gratuito da Defensoria Pública, conforme dispõem o artigo $5^{\circ}$, inciso LXXIX e o artigo 134 da Constituição Federal. Referidas previsões corroboram a importância do comparecimento pessoal do advogado ao ato de inquirição do acusado. 


\section{A REFORMA DA SISTEMÁTICA PROCESSUAL PENAL}

\section{1 - O Escopo da reforma do Código de Processo Penal}

Recentemente, diante da denominada minirreforma do Código de Processo Penal, foram promulgadas as Leis $\mathrm{n}^{\circ} 11.689,11.690$ e 11.719 , todas do ano de 2008, alterando alguns dos seus dispositivos, especialmente no tocante ao procedimento do Tribunal do Júri, às provas, bem como implementando modificações no rito ordinário, na mutatio e emendatio libeli, dentre outras inovações.

Tratam-se das primeiras de uma série de mudanças que o Código de Processo Penal sofrerá ${ }^{81}$, de modo a adequá-lo à nova sistemática constitucional, alterando dispositivos que se revelam incompatíveis com a Constituição Federal, bem como já ultrapassados pelo tempo, buscando uma celeridade e efetividade maior aos trâmites processuais.

O Código de Processo Penal, atualmente em vigor, foi editado em plena Era Vargas, no ano de 1941, tendo sofrido forte influência da doutrina fascista, ostentando, portanto, uma mentalidade extremamente policialesca. Assim, traz em sua essência um sistema processual de viés inquisitivo, com poucas garantias ao acusado submetido à persecução penal.

\footnotetext{
${ }^{81}$ Ressalte-se que a Comissão de Reforma do Código de Processo Penal, além das recentes alterações, elaborou um anteprojeto de um novo Código, e que já foi convertido no Projeto de Lei $\mathrm{n}^{\circ} 156$ no Senado Federal. Dentre as novidades do futuro código está a previsão expressa de princípios fundamentais aplicáveis à persecução penal, bem como a limitação temporal da prisão preventiva. Disponível em <www.senado.gov.br $>$.
} 
De outro lado, a Constituição Federal de 1988 foi promulgada em um cenário de redemocratização e mostrou-se extremamente preocupada com a afirmação e positivação de direitos e garantias fundamentais do cidadão, especialmente no processo penal, consagrando um modelo acusatório de processo, preocupação essa observada ao longo de seus dispositivos.

Diante de tal fato, Fauzi Hassan Choukr assinala que a situação brasileira é de contradição, pois “De um lado o texto constitucional (que adotou o modelo acusatório); por outro o Código de Processo Penal, com seus resquícios inquisitivos". 82

Entretanto, o legislador procurou mitigar tais incompatibilidades com a realização de algumas alterações pontuais ao longo dos anos. Analisando o contexto dessas modificações, aduz Abel Fernandes Gomes:

\begin{abstract}
"Dentro desse espectro, que abrange legislação e jurisprudência, é possível relacionar uma série de modificações que transmudaram teórica e empiricamente o processo disciplinado no Código de 1941, a ponto de pelo menos repercutir o ideal de uma Justiça penal mais conciliatória e aberta à vontade das partes, e de afastar a legitimação de determinadas condutas das autoridades encarregadas da persecução penal, naquilo em que ainda procuram se ater a práticas autoritárias de apuração do delito e solução do conflito criminal. " $\$ 3$
\end{abstract}

Todavia, apesar dessa preocupação legislativa, o Código de Processo Penal ainda se mostra um diploma recheado de lacunas, ainda não totalmente em consonância com os princípios constitucionais aplicáveis ao processo, bem

\footnotetext{
${ }^{82}$ CHOUKR, Fauzi Hassan. Processo penal à luz da Constituição. São Paulo: Edipro, 1999. p. 16.

${ }^{83}$ GOMES, Abel Fernandes et al. Persecução Penal e Devido Processo Legal no Brasil e na Common Law Tradition - Análise Histórica e Comparativa à Luz da Aplicação de Princípios Democráticos. In: Revista da Seção Judiciária do Rio de Janeiro. n. 22. jun. 2008. p.17-35. Dentre os exemplos do autor, cite-se a Lei 9.099/95, que trata dos Juizados Especiais Cíveis e Criminais, trazendo maior participação do acusado no processo, com a possibilidade de conciliação em torno da infração penal, sua prática e processamento; a Lei 10.792/03, a qual alterou a sistemática anterior do interrogatório, ao garantir que o silêncio do acusado agora não seja levado em conta contra a sua defesa; a Lei 11.449/07 passou a determinar o envio de cópia do auto de prisão em flagrante para a Defensoria Pública, em 24 horas, quando o autuado não indicar advogado.
} 
como às garantias e direitos do réu, contendo resquícios de inquisitorialidade em alguns de seus dispositivos. ${ }^{84}$

Referida questão se deve, em parte, ao fato da não realização de um grande estudo, sistemático e abrangente, analisando o Código de Processo Penal como um todo. As mudanças sempre foram pontuais, abrangendo um tema específico, não atentando para uma análise global do sistema e os reflexos que uma alteração ocasionaria em seu seio. Nessa linha, observa o Ministro Hamilton Carvalhido, Presidente da Comissão de Reforma do Código de Processo Penal:

"O atual Código de Processo Penal regula o trâmite que vai da investigação criminal à sentença judicial e seus recursos e possui 811 artigos, distribuídos em cinco livros. Diversas modificações foram introduzidas ao longo de mais de meio século e mudanças na legislação alteraram seu teor, mas deixaram vazios que comprometem os princípios penais". ${ }^{85}$

Ainda de acordo com o Ministro Hamilton Carvalhido, a tentativa ou orientação de propostas parciais de alteração do Código traz um defeito que só o tempo revela: criam-se lacunas que comprometem a eficácia do sistema:

"Elas às vezes criam contradições dentro do sistema e produzem resultados que não são aqueles desejados num Estado democrático de direito". ${ }^{86}$

Deste modo, a atual Comissão de Reforma se mostrou preocupada em harmonizar ao máximo os dispositivos do Código de Processo Penal, preenchendo as lacunas outrora expostas.

\footnotetext{
${ }^{84}$ A título de exemplo temos o artigo 10, $\S 1^{\circ}$, do Código de Processo Penal, dispondo que o relatório da Autoridade Policial será remetido ao juiz competente e não ao Ministério Público, órgão constitucionalmente encarregado de iniciar, privativamente, a ação penal, conforme o artigo 129, I, da Constituição Federal. Percebe-se que tal artigo ainda retrata uma necessidade de grande participação do magistrado nessa fase pré-processual.

${ }^{85}$ Código de Processo Penal: em busca de uma legislação efetiva. Notícia disponível em $\langle$ www.stj.gov.br〉.

${ }^{86}$ Ibid.
} 
Além disso, trabalhou na maior efetivação dos direitos fundamentais do cidadão e na afirmação dos princípios constitucionais, já que, atualmente, "não é mais admissível compreender e muito menos seguir aplicando o processo penal sem a filtragem constitucional" ${ }^{87}$

Importante ressaltar, também, que o Código de Processo Penal de 1941 não está superado apenas pelo tempo; está superado também por força da incompatibilidade normativa com o texto de 1988, em cujo bojo construiu-se um sistema de garantias individuais com abrangência suficiente para evaporar diversos dispositivos do nosso Código. ${ }^{88}$

Por tal motivo, a reforma buscará, de um lado, agilizar os trâmites processuais instituídos pelo vetusto Código de 1941, trazendo maior celeridade e efetividade à jurisdição penal; em seu outro viés, consagrará e afirmará as garantias individuais e direitos fundamentais do acusado que devem ser observadas em toda e qualquer persecução penal, a fim de permitir um processo justo.

Apesar da ascensão da violência em níveis cada vez maiores e da cobrança social acerca de uma resposta célere e eficaz a tais agressões, muitas vezes sustentando a aplicação de medidas que mitigam substancialmente direitos e garantias do réu, buscando um processo com viés tão somente punitivo $^{89}$, a reforma parece que não cedeu a tais apelos imediatistas,

\footnotetext{
${ }^{87}$ OLIVEIRA, Eugênio Pacelli de. Curso de Processo Penal. 10 ${ }^{\mathrm{a}}$ ed. Rio de Janeiro: Lumen Juris, 2008. p. 3.

${ }^{88}$ Ibid. p. 3.

${ }^{89}$ Essa preocupação, conforme Abel Fernades Gomes, ainda se mostra estampada no item II, da Exposição de Motivos do Código de Processo Penal, o qual possui como objetivo a "maior eficiência e energia da ação repressiva do Estado contra os delinqüentes". GOMES, Abel Fernandes et al. Persecução Penal e Devido Processo Legal no Brasil e na Common Law Tradition-Análise Histórica e Comparativa à Luz da Aplicação de Princípios Democráticos. In: Revista da Seção Judiciária do Rio de Janeiro. n. 22. jun. 2008. p. 17-35.
} 
preocupando-se com a agilização dos feitos, mas sem descuidar ou relegar a segundo plano as garantias dos acusados.

Maurício Zanóide de Moraes, analisando esse clamor popular pela maior punição em cotejo com as garantias fundamentais que a reforma traz para o seio do processo penal, tece a seguinte observação:

"O processo penal e mais justo não é o que pune mais, não é o que pune menos, somente o rico ou o pobre. O processo justo é aquele que pune, com todas as garantias e com maior eficiência, os culpados e não pune, talvez idealmente, os inocentes. $" 90$

A sociedade, não raras vezes, não compreende que a adoção de garantias e direitos no âmbito do processo penal não conduz a privilegiar criminosos ou dificultar a apuração e condenação dos delitos perpetrados. Trata-se somente de conformar as regras processuais à Constituição de 1988, extremamente democrática e preocupada em não só prever formalmente garantias e direitos, mas sim em vê-los postos em prática e sendo respeitados por todos.

Nessa linha, conforme o Ministro Hamilton Carvalhido, a reforma processual visa implementar um sistema processual que proteja os direitos fundamentais do cidadão, transformando o lado autoritário da legislação numa disciplina que põe no devido lugar o direito fundamental da liberdade. ${ }^{91}$

Apresentada as linhas gerais da reforma processual penal, passa-se, agora, a analisar de modo breve algumas das mudanças instituídas.

\footnotetext{
90 Código de Processo Penal: em busca de uma legislação efetiva. Notícia disponível em <www.stj.gov.br>.

${ }^{91}$ Ibid.
} 


\section{2 - Algumas modificações da legislação processual penal}

A preocupação da reforma com a afirmação dos princípios constitucionais aplicáveis no âmbito processual penal revela-se, inicialmente, na previsão do caput e do $\S 1^{\circ}$ do novo artigo 157 , alterado pela Lei 11.690/09, in verbis:

“Art. 157 - São inadmissíveis, devendo ser desentranhadas do processo, as provas ilícitas, assim entendidas as obtidas em violação a normas constitucionais ou legais.

$\S 1^{\underline{o}}$ São também inadmissíveis as provas derivadas das ilícitas, salvo quando não evidenciado o nexo de causalidade entre umas e outras, ou quando as derivadas puderem ser obtidas por uma fonte independente das primeiras".

Agora, o Código de Processo Penal expressamente adota o princípio da vedação às provas obtidas por meios ilícitos, já consagrado no texto constitucional no artigo $5^{\circ}$, inciso LVI, prevendo o novo artigo, em conseqüência, a extração dos autos dessa espécie de prova.

Cabe ressaltar que tal previsão atua no controle da atividade persecutória estatal, vedando a adoção de práticas probatórias ilegais por parte dos agentes públicos, tutelando, assim, concomitantemente, os direitos e garantias do acusado, bem como a qualidade do material probatório constante dos autos e que servirá de base para o convencimento judicial. ${ }^{92}$

Por outro lado, o parágrafo $1^{\circ}$, do artigo 157 , consagrou na ordem processual penal a Teoria dos Frutos da Árvore Envenenada (fruits of the poisonous tree), advinda do direito norte americano, e que já era aceita por

92 OLIVEIRA, Eugênio Pacelli de. Curso de Processo Penal. 10ª ed., Rio de Janeiro: Lumen Juris, 2008. p. 295. 
nossa doutrina e aplicada nos tribunais ${ }^{93}$ mesmo antes da reforma, muito embora não estivesse disposta em lei.

Também denominada ilicitude por derivação, tal teoria impede que o agente produtor da prova ilícita se valha desta para alcançar novas provas, as quais, logicamente, estariam contaminadas pela ilicitude primária.

Ainda no tocante à prova, agora na seara da prova pericial, a Lei 11.690/08 alargou a participação das partes no processo, conferindo, no artigo $159, \S 3^{\circ}$ e $\S 4^{\circ}$, a possibilidade do Ministério Público, do assistente de acusação, do ofendido, do querelante e do acusado formularem quesitos ao perito oficial, bem como indicarem assistente técnicos de sua confiança, figura, até o momento, inexistente no processo penal. ${ }^{94}$

Sem dúvida, tal inovação contribui para uma qualidade maior da prova, alargando a possibilidade de contestação dos laudos oficiais, em homenagem ao princípio do contraditório, insculpido no artigo $5^{\circ}$, inciso $\mathrm{LV}$, da Constituição Federal. Nesse sentido, Luiz Flávio Gomes considerou tal medida de extrema importância:

"Salutar a iniciativa do legislador. Afinal, prestigiou o princípio da ampla defesa e do contraditório, fortemente ameaçados pela omissão da lei anterior quanto à possibilidade de indicação de assistentes técnicos pelas partes (...). ${ }^{95}$

\footnotetext{
${ }^{93} \mathrm{O}$ Supremo Tribunal Federal já inadmitia as provas ilícitas por derivação como se observa do seguinte julgado: "Ninguém pode ser investigado, denunciado ou condenado com base, unicamente, em provas ilícitas, quer se trate de ilicitude originária, quer se cuide de ilicitude por derivação. Qualquer novo dado probatório, ainda que produzido, de modo válido, em momento subseqüente, não pode apoiar-se, não pode ter fundamento causal nem derivar de prova comprometida pela mácula da ilicitude originária. - A exclusão da prova originariamente ilícita - ou daquela afetada pelo vício da ilicitude por derivação - representa um dos meios mais expressivos destinados a conferir efetividade à garantia do "due process of law" e a tornar mais intensa, pelo banimento da prova ilicitamente obtida, a tutela constitucional que preserva os direitos e prerrogativas que assistem a qualquer acusado em sede processual penal. STF, RHC n. 90.376, Rel. Ministro Celso de Mello, Brasília, 03 abr. 2007.

${ }^{94}$ Luiz Flávio Gomes observa que a figura do assistente técnico só existia no Processo Civil antes da Reforma do Código de Processo Penal. GOMES, Luiz Flávio et al. Comentários às Reformas do Código de Processo Penal e da Lei de Trânsito. ${ }^{\text {a }}$ ed. São Paulo: Revista dos Tribunais, 2008. p. 290. ${ }^{95}$ Ibid. p. 290.
} 
De outro giro, a Lei 11.690/08 trouxe importante mudança no tocante à inquirição de testemunhas durante o rito ordinário.

O novo artigo 212, em seu caput e parágrafo único, tratou da matéria, como se observa nas novas disposições:

"Art. 212 - As perguntas serão formuladas pelas partes diretamente à testemunha, não admitindo o juiz aquelas que puderem induzir a resposta, não tiverem relação com a causa ou importarem na repetição de outra já respondida.

Parágrafo único. Sobre os pontos não esclarecidos, o juiz poderá complementar a inquirição. " $(N R)$

Agora, as perguntas não precisam mais ser transmitidas ao juiz para que este, ato contínuo, as retransmita às testemunhas, procedimento este que só contribuía para uma burocratização da audiência e para sua maior duração, em um formalismo que se mostrava despido de relevância prática.

As partes, assim, já podem inquirir diretamente as suas próprias testemunhas, bem como as da parte contrária, técnicas estas já observadas no direito anglo-saxão e denominadas direct examination (exame direto) e cross examination (exame cruzado), respectivamente. ${ }^{96}$

Semelhante disposição encontra-se no artigo $473, \S 1^{\circ}$, modificado pela Lei 11.689, a qual alterou diversos dispositivos que regulavam a sistemática procedimental do Tribunal do Júri. Portanto, nesse procedimento, as partes também inquirirão diretamente as testemunhas. ${ }^{97}$

\footnotetext{
${ }^{96}$ DIDIER, Fredie. Editorial $n^{o} 40$. Disponível em <www.frediedidier.com.br $>$.

${ }^{97}$ Anteriormente à reforma, muito embora existisse aceso debate na doutrina, grande parte desta reconhecia a possibilidade da inquirição direta das testemunhas no procedimento do Tribunal do Júri, com base na interpretação do artigo 468 do antigo diploma. Nesse sentido, a opinião de Luiz Flávio Gomes. GOMES, Luiz Flávio et al. Comentários às Reformas do Código de Processo Penal e da Lei de Trânsito. $1^{\mathrm{a}}$ ed. São Paulo: Revista dos Tribunais, 2008. p. 168.
} 
Todavia, no Júri, deve-se atentar a um detalhe: diferentemente do rito ordinário, que prevê que o juiz atuará ao final dos depoimentos, somente a título de complementação de seu convencimento, a inquirição das testemunhas em plenário inicia-se com a tomada dos depoimentos pelo juiz-presidente, conforme se depreende da leitura do artigo 473, caput do Código de Processo Penal.

Apesar dessa diferença, tais disposições relativas à inquirição de testemunhas receberam aplausos da doutrina, já que coadunam-se com uma estrutura de processo penal na qual "o juiz deve assumir a posição de maior neutralidade na produção da prova, evitando-se o risco de tornar-se o magistrado um substituto do órgão da acusação". 98

Assim, o juiz interferirá de modo menos enfático na coleta de provas, somente formulando perguntas caso queira esclarecer algum ponto que não lhe pareceu claro ou mesmo que não foi abordado pelas partes. Preserva-se, sem dúvida, de maneira mais eficaz sua imparcialidade, ditame de viés constitucional, e que concorre para um julgamento mais justo do processo.

O próximo tópico abordará a situação do interrogatório do réu na nova sistemática processual instituída pela reforma, sendo analisadas as mudanças trazidas com a Lei 11.719/08 quanto ao procedimento ordinário.

\section{3 - O Interrogatório na nova sistemática processual penal}

A Lei 11.719/08 alterou dispositivos relativos à suspensão do processo, emendatio libelli, mutatio libelli e aos procedimentos. A partir de agora, serão

${ }^{98}$ OLIVEIRA, Eugênio Pacelli de. Curso de Processo Penal. 10 a ed. Rio de Janeiro: Lumen Juris, 2008. p. 356. 
analisadas somente as mudanças ocorridas no rito ordinário e no Tribunal do Júri, concretizando a nova posição adquirida pelo interrogatório.

Inicialmente, cabe apontar que a Lei $11.719 / 08$, em seu artigo $394, \S 1^{\circ}$, estabeleceu que o procedimento comum subdivide-se em ordinário, sumário e sumaríssimo a depender do quantum da pena privativa de liberdade prevista para o delito.

Deste modo temos que penas privativas de liberdade superiores a 4 anos ensejarão o trâmite pelo rito ordinário; cominações até o mesmo patamar remeterão o caso para o rito sumário; por fim, o rito sumaríssimo é aplicado quando estivermos diante de uma infração de menor potencial ofensivo. ${ }^{99}$

No tocante ao rito ordinário foram realizadas grandes reformas atinentes ao procedimento.

Diferentemente da sistemática anterior, o réu não é mais citado para ser interrogado em juízo, sendo, ao contrário, intimado para apresentar uma defesa preliminar, conforme preceitua o novo artigo 396, caput:

"Nos procedimentos ordinário e sumário, oferecida a denúncia ou queixa, o juiz, se não a rejeitar liminarmente, recebê-la-á e ordenará a citação do acusado para responder à acusação, por escrito, no prazo de 10 (dez) dias". 100

Como se vê, o interrogatório deixa de ocupar o posto primário que detinha, sendo aberta ao réu a oportunidade de apresentar uma defesa prévia,

\footnotetext{
${ }^{99}$ De acordo com o artigo 61, da Lei 9.099/95, “consideram-se infrações penais de menor potencial ofensivo, para os efeitos desta Lei, as contravenções penais e os crimes a que a lei comine pena máxima não superior a 2 (dois) anos, cumulada ou não com multa". Note-se que a definição do rito foi modificada, já que, anteriormente à reforma, sua definição ocorria levando-se em conta o fato da pena privativa de liberdade ser de reclusão ou de detenção.

${ }^{100}$ Somente a título de observação, note-se que a sistemática do artigo 396, prevendo o recebimento da denúncia antes da abertura do prazo para a defesa, não foi a propugnada no Projeto de Lei que deu origem ao dispositivo, no qual era prevista a defesa preliminar do acusado antes do recebimento da denúncia ou da queixa, conforme concebido por Ada Pellegrini Grinover e Rui Stoco. In GOMES, Luiz Flávio et al. Comentários às Reformas do Código de Processo Penal e da Lei de Trânsito. $1^{\mathrm{a}}$ ed. São Paulo: Revista dos Tribunais, 2008. p. 290..
} 
sendo possível alegar basicamente "tudo o que interesse à sua defesa", conforme previsto no artigo 396-A, do Código de Processo Penal, ampliando o exercício do contraditório e da ampla defesa.

Apresentada a defesa preliminar, é aberta a possibilidade do juiz, desde logo, absolvê-lo sumariamente, caso vislumbre no caso concreto estar diante de uma causa excludente de ilicitude ou culpabilidade, de um fato atípico ou de uma causa extintiva da punibilidade, conforme preceitua o novo artigo 397.

Analisando tal dispositivo, temos a lição do Procurador de Justiça Rômulo Andrade Moreira:

"Estas hipóteses diferem formal e substancialmente da rejeição liminar da peça acusatória (ou do não recebimento, como prefiram, pois a absolvição sumária é uma decisão de mérito, passivel de fazer coisa julgada material (intangível e absolutamente imutável) e que desafia o recurso de apelação (art. 593, I). ${ }^{101}$

Não se tratando da hipótese de absolvição sumária, o juiz marcará a data para o início da instrução judicial, a qual sofreu relevantes alterações pela Lei $11.719 / 08$.

Antes da reforma, tínhamos a instrução criminal, de modo resumido, dividida do seguinte modo: interrogatório do réu, como primeiro ato do procedimento, seguido da apresentação da defesa prévia, oitiva das testemunhas de acusação, oitiva das testemunhas de defesa, fase de requerimento de diligências, alegações finais e a conclusão para a sentença.

Note-se que a realização de cada ato acima disposto ocorria em um dia diferente, de modo que não era raro transcorrer período relativamente longo entre o interrogatório e os sumários de acusação e defesa, retardando toda a dinâmica processual.

\footnotetext{
${ }^{101}$ MOREIRA, Rômulo de Andrade. A Reforma do Código de Processo Penal - Procedimentos. Disponível em <www.ibccrim.com.br>.
} 
Em sintonia com o princípio da razoável duração do processo, previsto no artigo $5^{\circ}$, inciso LXXVIII, estabelecendo uma celeridade maior à instrução criminal, o reformulado artigo 400 caput e seu $\S 1^{\circ}$ dispõem acerca da realização de todos os atos processuais ${ }^{102}$ em uma única audiência:

"Art. 400 - Na audiência de instrução e julgamento, a ser realizada no prazo máximo de 60 (sessenta) dias, proceder-se-á à tomada de declarações do ofendido, à inquirição das testemunhas arroladas pela acusação e pela defesa, nesta ordem, ressalvado o disposto no art. 222 deste Código, bem como aos esclarecimentos dos peritos, às acareações e ao reconhecimento de pessoas e coisas, interrogando-se, em seguida, o acusado.

$\S 1^{1^{o}}$ As provas serão produzidas numa só audiência, podendo o juiz indeferir as consideradas irrelevantes, impertinentes ou protelatórias."

Assim, todos os atos, incluindo a sentença ${ }^{103}$, deverão ser realizados em um único dia, de forma oral, em homenagem aos princípios da imediatidade, da oralidade e da concentração dos atos processuais. ${ }^{104}$

O interrogatório, como se observa, é o último ato do processo, possibilitando ao acusado e ao seu defensor tomar conhecimento de todo o material probatório produzido antes do réu prestar declarações ao juízo.

Deste modo, o acusado terá ciência, quando de seu interrogatório, dos depoimentos de todas as testemunhas arroladas, bem como o resultado das perícias realizadas, o que contribui de forma extremamente benéfica para o exercício de sua autodefesa.

Na sistemática antiga, na qual era ouvido antes de todas as testemunhas, não poderia o réu exercer essa autodefesa plena, somente sendo possível

\footnotetext{
102 Cabe ressaltar que não há mais a antiga defesa prévia, oferecida após o interrogatório do réu.

${ }^{103}$ Conforme o artigo 403, caput, a sentença será proferida em audiência, após alegações finais orais por parte do Ministério Público e do defensor do acusado, sendo tal regra afastada somente no caso do juiz entender tratar-se de uma causa de grande complexidade, como disposto no $\S 3^{\circ}$ do mesmo dispositivo legal. Caso assim decida, as partes apresentarão memoriais no prazo de 5 dias.

${ }_{104}$ MOREIRA, Rômulo de Andrade. A Reforma do Código de Processo Penal - Procedimentos. Disponível em <www.ibccrim.com.br>.
} 
contraditar o depoimento de uma testemunha de acusação por intermédio de perguntas realizadas por seu advogado à mesma.

A doutrina já atentava para a inconveniência do interrogatório como primeiro ato do processo, já que, desse modo, era quebrada a clássica idéia de que a defesa tem a última palavra. Assim, diante de uma estrutura acusatória de processo, a melhor posição do interrogatório seria como último ato do procedimento. $^{105}$

No mesmo sentido era a crítica formulada por Antonio Scarance Fernandes:

"Com a posição de que é (o interrogatório) manifestação de autodefesa garantida constitucionalmente, melhor inseri-lo, no procedimento, como ato posterior ao da inquirição das testemunhas". ${ }^{106}$

Realmente não há como exercitar uma defesa de modo pleno e eficaz se não há conhecimento do que alegaram as testemunhas de acusação e defesa, sendo de grande importância a realocação da posição do interrogatório no rito ordinário.

Note-se que a nova sistemática do interrogatório, introduzida pela Lei 11.719/08, já era aplicada no rito dos Juizados Especiais Criminais, com previsão no artigo 81, da Lei 9.099/95, sendo apontada pela doutrina como uma medida que garantia a ampla defesa do acusado em juízo ${ }^{107}$, ademais por se tratar o interrogatório de um autêntico meio de defesa.

A título de ilustração, a fim de demonstrar a importância do interrogatório como último ato processual, é possível imaginar a situação do

105 CHOUKR, Fauzi Hassan. Código de Processo Penal: Comentários Consolidados e Crítica Jurisprudencial. $2^{\text {a }}$ ed., Rio de Janeiro: Lumen Juris, 2007, p. 343.

106 FERNANDES, Antonio Scarance. Teoria Geral do Procedimento e Procedimento no Processo Penal. São Paulo, RT, 2005, p.141 apud GOMES, Luiz Flávio et al. Comentários às Reformas do Código de Processo Penal e da Lei de Trânsito. $1^{a}$ ed. São Paulo: Revista dos Tribunais, 2008. p. 290. ${ }^{107}$ JARDIM, Afrânio Silva. "Juizados Especiais Criminais". In: Direito Processual Penal. 8 a ed., Rio de Janeiro: Forense, 1999, p. 366. 
acusado, que com as perguntas formuladas por seu advogado, poderá contraditar o depoimento de uma testemunha de acusação, trazendo elementos ao juízo de que a mesma se equivoca em relação ao que diz ou mesmo atua na tentativa de iludir o juízo, de modo a retirar todo o crédito de seu depoimento.

Permite-se, ademais, uma análise mais acurada por parte do réu acerca da conveniência e oportunidade de exercer seu direito ao silêncio e a não autoincriminação, pois detém o conhecimento de todo o material probatório produzido, optando pelo melhor caminho a seguir.

Ou seja, como o acusado será o último a ser ouvido no feito, "poderá, livremente, escolher a estratégia de autodefesa que melhor consulte aos seus interesses". 108

Referida alteração é ainda mais relevante no interrogatório realizado no Tribunal do Júri.

Afirma-se tal fato, pois no júri as declarações do réu são primordialmente direcionadas a influir no ânimo dos jurados, os quais, ao final, decidirão acerca de sua liberdade.

Possuindo ciência acerca de todos os fatos e provas produzidas em plenário, resta ampla a capacidade de exercer uma defesa convincente aos olhos dos jurados, guiados em suas reflexões finais muito mais por questões fáticas e emocionais do que por tecnicismos e detalhes da legislação penal.

Declarações e teses defensivas que ao juiz podem parecer insuficientes a embasar uma absolvição são passíveis de outra leitura por parte dos jurados, leigos, em regra, no mundo jurídico. ${ }^{108}$ OLIVEIRA, Eugênio Pacelli de. Curso de Processo Penal. $10^{\mathrm{a}}$ ed., Rio de Janeiro: Lumen Juris,
2008. p. 326. 
Tendo em vista que as declarações do réu se direcionam muito mais aos jurados do que ao magistrado, este, quando da realização das perguntas ao réu em plenário, deve resguardar sua imparcialidade ao máximo, a fím de não transparecer sua opinião acerca do caso, influenciando, deste modo, o pensar dos jurados.

Cabe ressaltar que a mudança efetuada pelo legislador ordinário atua na defesa dos postulados constitucionais da ampla defesa e do contraditório, reafirmando, assim, os valores e princípios constitucionais aplicáveis ao processo penal e que devem nortear sua leitura e interpretação.

Além da mudança da ordem procedimental do interrogatório, houve mudanças no tocante a forma de sua realização.

No rito ordinário, como não há dispositivo algum acerca da forma de realização do interrogatório, manteve-se a aplicação dos dispositivos dos artigos 185 e seguintes, devendo o Juiz iniciar a inquirição, sendo possível às partes, por intermédio do Juiz, formularem perguntas ao acusado.

A grande mudança ocorreu no interrogatório do réu no rito do Tribunal do Júri, permitindo-se às partes inquirirem diretamente o réu em plenário, conforme preceitua o novo artigo $474 \S 1^{\circ}$ :

"Art.474 - A seguir será o acusado interrogado, se estiver presente, na forma estabelecida no Capítulo III do Título VII do Livro I deste Código, com as alterações introduzidas nesta Seção.

$\S 1^{o}$ O Ministério Público, o assistente, o querelante e o defensor, nessa ordem, poderão formular, diretamente, perguntas ao acusado."

Assim, as partes elaborar questionamentos diretamente ao acusado, afastando o trâmite burocrático de formular a pergunta pretendida ao juiz para que, só assim, esse indagasse o réu. 
Confere-se, com tal iniciativa legislativa, uma maior participação das partes no ato de interrogatório do réu perante o Tribunal do Júri, alteração essa que também ocorreu na inquirição das testemunhas no rito ordinário, como visto anteriormente.

Diante de tal mudança, conclui Eugênio Pacelli que "o interrogatório não pode mais ser considerado ato privativo do juiz. Muito ao contrário, a sua atuação deve ser complementar." 109 Tal dispositivo só vem a incrementar e reforçar nosso sistema processual penal, baseado num modelo acusatório de persecução.

Essa maior participação das partes na instrução, afastando o magistrado, o qual, agora, só irá complementar os pontos que lhe parecerem pouco esclarecidos, aproxima nosso modelo de processo, instituído sob o prisma do civil-law, do sistema adversarial, típico do mundo anglo-saxão, que adota o common-law.

José Carlos Barbosa Moreira, analisando os sistemas do civil-law e do common-law, no tocante a essa participação das partes na instrução, leciona na seguinte linha:

"O confronto entre civil law e common law tem sido feito por diversos prismas. No
campo do processo, é critério recorrente o que se tira da "divisão do trabalho"
entre juiz e partes (rectius: entre juiz e advogados das partes) na instrução
probatória. Adverte-se aí uma diferença de acentuação: os ordenamentos anglo-
saxônicos atribuem a tarefa principalmente aos advogados, enquanto nos da família
romano-germânica assume relevância maior o papel do órgão judicial. Cunharam-
se até denominações, no âmbito do common law, para assinalar o contraste: ao
processo do tipo dominante na família romano-germânica chama-se 'inquisitorial',
ao outro tipo 'adversarial". ${ }^{110}$

109 OLIVEIRA, Eugênio Pacelli de. Curso de Processo Penal. $10^{\mathrm{a}}$ ed., Rio de Janeiro: Lumen Juris, 2008. p. 332.

${ }_{110}$ MOREIRA, José Carlos Barbosa. Processo civil contemporâneo: um enfoque comparativo. In Temas de direito processual. $9^{\mathrm{a}}$ série. São Paulo: Saraiva, 2007, p. 41 apud $O$ contraditório e a prova no processo penal: breves comentários à Lei 11.690 de 2008. PIMENTA, Haroldo. O Contraditório e a prova no processo penal.: breves comentários à Lei 11.690, de 2008. Disponível em: < http://www.ejef.tjmg.jus.br/home/> 
Por fim, cabe uma observação acerca do tratamento diferenciado do interrogatório no rito ordinário em relação ao conferido no Tribunal do Júri, especificamente no tocante à participação do magistrado em tal ato.

No rito ordinário, o juiz continua exercendo o papel de destaque no interrogatório, comandando tal ato processual, já que cabe a ele iniciá-lo, sendo permitido às partes, após a inquirição judicial, formular perguntas ao acusado, com a intermediação do magistrado.

De outro lado temos o interrogatório do réu em plenário, obedecendo a regras diversas: as partes iniciam o interrogatório do acusado, formulando perguntas diretas ao réu, sem a intermediação do juiz. Ao final, o magistrado, entendendo necessário, poderá complementar a inquirição com suas indagações, não exercendo, como se observa, papel de destaque em tal ato.

O tratamento conferido à participação do magistrado no interrogatório realizado sob o rito ordinário é um, enquanto que o dispensado no Tribunal do Júri é outro, evidência que não se apresenta de bom grado, já que a reforma processual também objetiva conferir uma maior coerência ao ordenamento.

Sendo assim, a fim de alinhar o rito de inquirição com o modelo acusatório, é necessária uma interpretação no sentido de que todo interrogatório, em qualquer rito, deve ser iniciado pelas partes, as quais inquirirão diretamente o acusado, cabendo o juiz apenas complementá-lo. Feito isso, confere-se unidade e coerência interna no âmbito de uma necessária sistematização da matéria. ${ }^{111}$

111 OLIVEIRA, Eugênio Pacelli de. Curso de Processo Penal. 10 a ed., Rio de Janeiro: Lumen Juris, 2008. p. 586. 


\section{O INTERROGATÓRIO POR VÍDEOCONFERÊNCIA}

\section{1 - A Utilização no Direito Estrangeiro.}

Não obstante as discussões existentes no Brasil acerca da implantação do sistema da videoconferência em nosso país é certo que tal método já é utilizado em diversos países mundo afora.

As justificativas e argumentações para tal iniciativa residem, na maioria dos casos, na questão da segurança pública, evitando deslocamentos dos presos e eventuais tentativas de fuga, na economia gerada por essa prática, pois não é necessário mobilizar contingente policial para o transporte do acusado, bem como na celeridade e efetividade que supostamente o sistema confere aos julgamentos perante o Poder Judiciário.

Nessa linha de idéias, adotam a videoconferência, entre outros países, Portugal, Canadá, Austrália, Índia, Inglaterra, Chile, Itália, Estados Unidos, Holanda, França, Cingapura e Timor Leste. ${ }^{112}$

A seguir, faz-se uma exposição mais detida de como vem sendo utilizado o interrogatório à distância em dois países: os Estados Unidos e a Itália.

\footnotetext{
${ }^{112}$ No Timor Leste, o sistema da videoconferência foi utilizado para a inquirição do General indonésio Wiranto, acusado de praticar crimes contra a humanidade, no ano de 1999, nesse país. In FIOREZE, Juliana. Videoconferência no Processo Penal Brasileiro: Interrogatório On-Line. Paraná: Juruá, 2008. p. 304.
} 


\section{2 - A Videoconferência no Direito Norte Americano}

Atualmente, nos Estados Unidos da América, a utilização de sistemas de videoconferência é amplamente difundida, aplicando-se tanto a processos cíveis quanto aos da esfera criminal. Regras autorizadoras e procedimentais são encontradas tanto na legislação processual federal quanto na de muitos dos 50 estados federados. $^{113}$

Observe-se que nos Estados Unidos, o pacto federativo confere ampla autonomia legislativa aos estados membros, os quais possuem competência para legislarem sobre matéria penal e processual penal, de modo que a instituição do sistema de interrogatórios por videoconferência por leis estaduais não viola as regras de distribuição de competência norteamericanas. $^{114}$

Um dos primeiros e principais casos em que o sistema de videoconferência foi utilizado nos Estados Unidos foi o que envolveu o professor Theodore Kaczynski, denominado Unabomber, preso no ano de 1996 no Estado de Montana e transferido para o Estado da Califórnia, onde responderia a diversas acusações acerca da prática de terrorismo.

Concomitantemente, foi iniciado um processo criminal a fim de apurar um homicídio a ele atribuído, em Nova Jersey, exatamente do lado oposto do país. Deste modo, com o objetivo de poupar recursos financeiros e a mobilização de policiais, bem como evitar riscos e dificuldades que o

\footnotetext{
${ }^{113}$ Ibid. p.303.

${ }^{114}$ Observe-se que no Brasil, a Constituição da República de 1988, em seu artigo 22, I, dispõem que é competência privativa da União legislar acerca de matéria penal e processual penal, vedando, portanto, que um Estado brasileiro, autonomamente, legisle acerca da implementação do sistema de interrogatório por videoconferência.
} 
deslocamento representava, optou-se pela realização da audiência criminal por meio da videoconferência. ${ }^{115}$

$\mathrm{Na}$ mesma linha, outro caso de grande repercussão mundial, no qual a videoconferência foi utilizada no interrogatório de um acusado, foi a do terrorista Timothy James McVeigh, responsável pela morte de 168 pessoas, após efetuar um bombardeio contra um prédio federal no Estado de Oklahoma. ${ }^{116}$

Como já assentado, diante da grande autonomia legislativa que os Estados americanos possuem, cada qual pode estabelecer, de igual modo, o seu próprio Código de Processo Penal, com regras próprias e atinentes a realidade local de cada região.

Assim, por exemplo, o Estado de Illinois elaborou o seu Código de Processo Criminal, prevendo na seção 106D-1 o aparecimento do acusado por videoconferência, desde que o Tribunal ou o Juiz não exijam a presença pessoal do réu. Referido diploma legal ressalta, ainda, a necessidade de existirem instalações adequadas e disponíveis nos presídios para a realização das audiências. ${ }^{117}$

Deste modo, o Tribunal do Município de Hillsborough, em Illinois, regulamentou a utilização da videoconferência, especificando como será efetuado, na pratica, tal procedimento:

\footnotetext{
${ }^{115}$ ARAS, Vladimir. Videoconferência no Processo Penal. Disponível em <www.jusnavegandi.com.br >.

${ }^{116}$ FIOREZE, Juliana. Videoconferência no Processo Penal Brasileiro: Interrogatório On-Line. Paraná: Juruá, 2008. p. 304.

${ }^{117}$ Ibid. 304.
} 
"Por ordem deste Tribunal, acusações e audiências no Município de Hillsborough podem ser administradas por sistema de teleconferência instalado entre o Palácio de Justiça Superior, O Tribunal do Distrito de Nashua e a Delegacia de Polícia de Nashua. Segundo este procedimento, o acusado, e seu advogado podem ver e ouvir o juiz na sala do tribunal, em um monitor de televisão, o qual é dividido em quatro seções, cada uma exibindo uma pessoa diferente, ou parte diferente da sala do tribunal. Semelhantemente, o juiz do tribunal pode ver e ouvir o acusado e seu advogado, os quais têm acesso a cinco monitores montados ao redor da sala do Tribunal." 118

Prevalece o entendimento, não só no Tribunal do Município de Hillsborough, bem como em diversos tribunais americanos que utilizam a videoconferência, de que a sua implementação está em consonância com as leis, bem como respeita a Constituição. Deste modo, sustenta-se que para o reconhecimento da violação do direito de estar presente do réu, são necessárias evidências de que, em sua ausência, as propriedades do devido processo legal foram atingidas ocasionando a negação de um direito constitucional subjacente. ${ }^{119}$

Por fim, interessante observar que em alguns Estados e Municípios, o interrogatório dos acusados por meio da videoconferência só pode ser realizado com o expresso consentimento dos mesmos, devendo ser ouvido na presença do juiz, caso não concorde com a utilização de tal método.

A título de exemplo, adotando essa postura, temos os Estados da Carolina do Norte e da Carolina do Sul, bem como os Tribunais Supremos do Havaí e New Hampshire. No mesmo sentido, o Código de Processo Criminal do Tennessee e o Código de Processo Criminal Federal dos EUA, admitem a

\footnotetext{
118 ARAS, Vladimir. Sociedade Digital. Teleinterrogatório não elimina nenhuma garantia processual. Disponível em: 〈www.conjur.com.br〉.

119 Essa linha de entendimento foi seguida, dentre outros, pelo Tribunal de Kankakee, em Massachusetts, pelo de Hillsborough, em Illinois, bem como pelo Tribunal de Ohio. In FIOREZE, Juliana. Videoconferência no Processo Penal Brasileiro: Interrogatório On-Line. Paraná: Juruá, 2008. p. 308. Observe-se, por fim, que o entendimento americano trabalha com a necessidade do acusado demonstrar que o procedimento lhe causou prejuízos.
} 
utilização da videoconferência desde que haja o consentimento da defesa do acusado. $^{120}$

Ou seja: torna-se uma escolha própria do réu ser interrogado ou não em tais condições, sopesando as circunstâncias do caso concreto e a melhor opção para exercitar o seu direito de defesa. A análise da conveniência e oportunidade, portanto, estão em suas mãos, nada lhe sendo imposto.

\section{3 - A Videoconferência no Direito Italiano}

Na Itália, tratados de cooperação internacional possibilitam a realização de audiências por videoconferência, a exemplo do artigo 10 da Convenção Européia de Cooperação Internacional, a qual permite a obtenção de provas no exterior por meio de tal sistema. Além disso, o Tratado de Assistência Recíproca com a Suíça, de 11.10.2001, dispõe acerca do "l'esame testimoniale a distanza", em audiência conduzida pela autoridade do Estado requerente, de acordo com suas próprias normas processuais. ${ }^{121}$

Todavia, a utilização da videoconferência na Itália passou a ser realizada em larga escala em ações criminais envolvendo as máfias sicilianas, napolitana e calabresa, com o intuito de proteger testemunhas e vítimas dessas organizações criminosas, resguardando a segurança pública local.Além disso, na Itália, revelou-se um método para isolar chefes desses grupos, evitando que suas orientações e comunicações alcancem comparsas no exterior dos presídios.

\footnotetext{
${ }^{120}$ Ibid. p.311-317.

${ }^{121}$ Ibid. p. 324.
} 
Tal procedimento de inquirição à distância envolvendo tais grupos denomina-se "collegamento audivisivo a distanza", ou ligação audiovisual à distância. $^{122}$

A necessidade de implantação da videoconferência se revelou imperiosa pelo governo italiano, diante da ampliação de grupos mafiosos e da resistência e confronto que impunham às forças policiais, em total menosprezo pelas autoridades de segurança pública.

Trata-se, em verdade, de apenas uma de uma série de medidas de iniciativa das autoridades tendentes a mitigar o poderio desses grupos e enfraquecê-los em diversos aspectos. Walter Maierovitch explica como se iniciou esse combate ao crime organizado na Itália e como foi a opção pelo modelo da videoconferência a fim de evitar contatos exteriores dos chefes da máfia com seus grupos:

\begin{abstract}
"A máfia italiana resolveu em 1993 fazer ataques a bomba em Milão, Florença e Roma. A máfia decretou guerra contra o Estado. Vieram as reações. E se fez o quê? Se mudou toda a estrutura de prevenção e repressão. E qual era o problema principal? Era que alguns líderes mafiosos presos continuavam a se comunicar com o exército mafioso. O problema era como cortar uma rede que tem a velocidade de uma rede de neurônios. Ao passo que a velocidade da rede do Estado é sempre muito lenta. Então, se estabeleceu um sistema disciplinar de cárcere duro, onde os chefões mafiosos passaram a ser blindados e colocados em duas ilhas. Recentemente, Bernardo Provenzano foi preso. Ele é o chefe do chefe da máfia e ficou foragido 42 anos. Ele foi preso em 11 de abril. Ele está numa cela onde é monitorado 24 horas. E a comunicação dele com a Justiça foi feita por vídeo-conferência." "123
\end{abstract}

Nesse sentido, Giancarlo Sandro Caselli, ex-chefe do pool antimáfia italiano, atualmente responsável pelo sistema carcerário do país, também aduz

\footnotetext{
${ }^{122}$ NALINI, Leandro. Visão Provinciana impede a evolução da videoconferência. Disponível em < www.conjur.com.br>.

${ }^{123}$ MAIEROVITHC, Walter. São Paulo virou uma Bagdá. Entrevista concedida ao jornalista Ricardo Noblat, do jornal O Globo. Disponível em: <www.oglobo.com.br $>$.
} 
as vantagens da videoconferência tendo como argumento de apoio principal a questão da preservação da segurança pública como um todo:

"Os interrogatórios são feitos por circuito interno de televisão. Dessa maneira, não há constrangimento para testemunhas e existe mais segurança para os setores que estão investigando mafiosos. Para evitar que os mafiosos fossem resgatados ou fizessem ameaças às testemunhas durante os interrogatórios, o Ministério Público passou a utilizar o que eles chamam de videoconferência." 124

Note-se que as argumentações principais para justificar o interrogatório à distância giram em torno da questão da segurança pública, ameaçada por tais grupos criminosos. Utiliza-se uma ferramenta jurídica a fim de tentar conter a expansão de tais grupos criminosos e diminuir seu poder.

Realizada essa breve incursão na utilização da videoconferência nos Estados Unidos e na Itália, passa-se a uma análise do modelo no território brasileiro, destacando-se os exemplos práticos em nosso país, a produção legislativa a respeito, até chegarmos à edição da recente Lei 11.900/09, de âmbito nacional, que incorporou o sistema do interrogatório à distância no Código de Processo Penal Brasileiro.

\section{4 - Introdução e a finalidade da Videoconferência no processo penal brasileiro}

Em nosso país, a utilização pioneira do sistema da videoconferência foi realizada pelo Juiz Edison Aparecido Brandão, na cidade de Campinas, no dia

\footnotetext{
124 BEZERRA, Ana Cláudia da Silva. Interrogatório on-line e a ampla defesa. Disponível em $<<$ http://sisnet.aduaneiras.com.br/lex/doutrinas/arquivos/interrogatorio.pdf $>$.
} 
27.08.1996, sob a justificativa de que muitos réus, os quais seriam interrogados, estavam em presídios muito distantes da sede do juízo. ${ }^{125}$

$\mathrm{Na}$ ocasião, o magistrado exigiu a presença de um defensor para acompanhar o acusado no presídio durante todo o interrogatório, bem como nomeou outro para acompanhar as indagações da sala do juiz, localizada no fórum.

Após essa iniciativa, em setembro do mesmo ano, o então juiz Luiz Flávio Gomes também interrogou dois réus à distância, tendo, porém, realizado perguntas aos acusados por intermédio de um sistema de email. ${ }^{126}$

Diferentemente do juiz Edson Brandão, o qual utilizou um sistema de imagem e som em tempo real, Luiz Flávio Gomes digitava as perguntas e as enviava por email, respondendo os réus do mesmo modo, com a ajuda de um escrivão e de seus advogados. Tratava-se, portanto, de um método de interrogatório onde as partes não se viam, respondendo a todas as indagações por escrito.

Luiz Flávio Gomes justifica a utilização desse sistema ressaltando a diminuição drástica dos gastos estatais com o transporte dos presos, sendo possível, de igual modo, obter uma punição mais célere. Ressalta, entretanto, que o sistema só deve ser utilizado caso o detento concorde, já que o comparecimento diante do magistrado é um direito seu. ${ }^{127}$

\footnotetext{
125 MADELENA, Pedro. Videoconferência: Interrogatório. Disponível em 〈www.amb.com.br〉.

126 GOMES, Luiz Flávio. Uso da videoconferência na Justiça. Boletim do Instituto Brasileiro de Ciências Criminais - IBCCRIM. n. 42, jun.1996.

127 Ibid. Observe-se que essa possibilidade de aquiescência do acusado com tal método de interrogatório, também é conferida ao mesmo em alguns tribunais norte-americanos, conforme visto anteriormente.
} 
Ressalte-se que, àquela época, apesar de existirem discussões acerca da implantação do sistema da videoconferência entre os operadores do direito, não havia previsão legal acerca dessa possibilidade no Código de Processo Penal.

Ao contrário, o Código de Processo Penal, antes da reforma instituída pela Lei 11.719/08, previa, e ainda mantém essa disposição, em seu artigo 185, $\S 1^{\circ}$, que a realização do interrogatório se daria, como regra, no estabelecimento prisional no qual se encontrava o preso, devendo o magistrado e auxiliares para lá se deslocar.

Caso não existisse segurança suficiente para a realização do ato no presídio, o acusado deveria ser conduzido ao fórum, a fim de ser interrogado pessoalmente pelo juiz. O Código, portanto, não fazia qualquer menção expressa à videoconferência.

Com a edição da Lei 11.719/08, a qual, como visto, efetuou significativas mudanças nos procedimentos criminais, foi modificado o artigo 399, introduzindo-se um $\S 1^{\circ}$, dispondo que "O acusado preso será requisitado para comparecer ao interrogatório, devendo o poder público providenciar sua apresentação."

Com a edição desta Lei a regra, portanto, é a da requisição do acusado para ser interrogado pessoalmente pelo magistrado, expedindo-se uma ordem judicial dirigida ao diretor do estabelecimento prisional, a fim de que o acusado seja apresentado no dia e hora designados pelo magistrado. ${ }^{128}$

\footnotetext{
${ }^{128}$ GOMES, Luiz Flávio et al. Comentários às Reformas do Código de Processo Penal e da Lei de
} Trânsito. $1^{\mathrm{a}}$ ed. São Paulo: Revista dos Tribunais, 2008. p.341. 
No entanto, malgrado o Código de Processo Penal ainda não tratasse do tema, o que só foi feito com a edição da Lei 11.900/09, analisada mais à frente, já existiam regulamentações esparsas editadas por tribunais e leis estaduais dispondo acerca da utilização da videoconferência país afora.

Dentre os diversos exemplos, pode-se citar o Provimento $\mathrm{n}^{\circ} 5$, de 20.06.2003, expedido pela Corregedoria Geral do Tribunal Regional Federal da $4^{\text {a }}$ Região, regulamentando a realização do interrogatório virtual ${ }^{129}$ :

“Art. 276. Fica autorizado o interrogatório do réu por carta precatória ou por videoconferência condicionada à conveniência do juiz processante, baseado na busca da verdade real e presunção de amplitude defensiva."

No mesmo sentido, há a Portaria $n^{\circ}$ 2.210/02, de 30.07.2002, expedida pela Presidência do Tribunal de Justiça do Estado da Paraíba. A título de curiosidade, cabe observar que a Paraíba foi o primeiro Estado da federação a regulamentar o interrogatório à distância no país. ${ }^{130}$

Conforme dados revelados pelo Tribunal Paraibano, os juízes aumentaram sua produtividade, realizando até 15 audiências diárias, sem sair de seus gabinetes. Antes da utilização da videoconferência o número era bem diferente, não alcançando mais do que quatro audiências diárias, o que trouxe, conforme o Tribunal, maior agilidade para a justiça deste estado. ${ }^{131}$

O Tribunal de Justiça da Paraíba, como base para sua argumentação, ressalta a grande economia com a escolta dos acusados e com o combustível utilizado pelos veículos que efetuam o transporte. Além disso, aduz que o

\footnotetext{
${ }^{129}$ ARAS, Vladimir. Videoconferência no Processo Penal. Disponível em <www.jusnavegandi.com.br>.

${ }^{130}$ FIOREZE, Juliana. Videoconferência no Processo Penal Brasileiro: Interrogatório On-Line. Paraná: Juruá, 2008. p. 272. Importante citar, também, a Portaria COGE 637, de 01.06.2005, expedida pela Desembargadora Federal da $3^{\text {a }}$ Região, Dra. Marli Ferreira, autorizando o uso desse sistema em estabelecimentos prisionais na cidade de Guarulhos, em São Paulo, em caráter experimental.

${ }^{131}$ NALINI, Leandro. Visão Provinciana impede a evolução da videoconferência. Disponível em: <www.conjur.com.br .
} 
sistema evita resgates de presos, bem como proporciona maior segurança e tranqüilidade aos mesmos.

Ilustrando este último benefício, o juiz Aluízio Bezerra Filho, assessor da presidência do Tribunal Paraibano, relembra o homicídio perpetrado por familiares de uma vítima, durante a realização de uma audiência, quando do interrogatório do acusado. ${ }^{132}$

Igual experiência, do interrogatório on-line, já foi realizada pelo Tribunal de Justiça do Rio de Janeiro.

Em dezembro de 2002, a $37^{\mathrm{a}}$ Vara Criminal da Capital realizou o interrogatório dos traficantes conhecidos sob a alcunha de "Marcinho VP", "Chapolim", "Gigante” e "My Thor", em um caso que envolvia a depredação, por parte dos acusados, da carceragem do Batalhão de Choque da Polícia Militar. O juiz responsável pela tomada dos depoimentos, Dr. Marcus Basílio, considerou a experiência bem sucedida, afirmando que é extremamente vantajosa, pois o magistrado pode observar as reações do réu pelo vídeo. ${ }^{133}$

Com o objetivo de regulamentar a matéria em âmbito estadual, a Governadora Rosinha Garotinho, em 02 de Junho de 2005, sancionou e promulgou a Lei 4.554/05, oriunda de iniciativa da Deputada Estadual Andréia Zito, aprovada pela Assembléia Legislativa do Rio de Janeiro, prevendo a possibilidade do Poder Executivo criar salas de videoconferência nas penitenciárias, a fim de proceder à oitiva dos réus.

\footnotetext{
${ }^{132}$ BEZERRA FILHO, Aluízio. PB é o primeiro estado a ter Lei que disciplina a teleaudiência. Disponível em: 〈www.conjur.com.br>

${ }^{133}$ TJ-RJ toma depoimentos de traficantes à distância. Notícia disponível em: 〈www.conjur.com.br〉.
} 
Em sua justificativa ao Projeto de Lei apresentado, a Deputada Andréia Zito tece as seguintes considerações a fim de justificar a implementação dos interrogatórios à distância:

"Diante dos assassinatos de que estão sendo vítimas os nossos magistrados, é de
suma importância buscarmos soluções para protegê-los, assim como às milhares de
pessoas que transitam pelo Fórum diariamente e que se vêem ameaçadas pela
presença dos criminosos de alta periculosidade, como exigem os procedimentos
judiciais. Além disso, os altos custos do deslocamento de detentos para a realização
de audiências seria resolvido com a criação de salas de videoconferência nos
presídios e nas Varas do Poder Judiciário.(...) O alarmante crescimento do índice de
violência urbana a que vem sendo submetida a sociedade pela ação do crime
organizado exige respostas rápidas do Poder Público constituído.",

Circunscrevem-se suas ponderações, portanto, nas questões atinentes à segurança pública, ameaçada por criminosos de alta periculosidade, bem como na economia que geraria aos cofres governamentais.

O Estado de São Paulo, através da Lei 11.819, de 05 de Janeiro de 2005, editada pela Assembléia Legislativa deste ente federativo, já havia, antes mesmo da iniciativa fluminense, regulamentado o interrogatório e a audiência de réus pelo sistema da videoconferência por intermédio de uma Lei formal. ${ }^{135}$

Referida iniciativa teve origem no Projeto de Lei $\mathrm{n}^{\circ} 704$, do ano de 2001, proposto pelo Deputado Estadual Edison Gomes. Em sua justificativa aponta, inicialmente, que o interrogatório por videoconferência "objetiva propiciar condições para que seja agilizada a prestação jurisdicional no Estado de São Paulo". ${ }^{136}$

\footnotetext{
${ }^{134}$ Disponível em: <www.alerj.rj.gov.br>.

${ }^{135}$ Logo após, como visto, em 02 de Junho do mesmo ano, a Assembléia Legislativa do Rio de Janeiro trilhou caminho idêntico, com a edição da Lei 4.554/05.

${ }^{136}$ Disponível em: 〈www.al.sp.gov.br〉.
} 
Ressalta, ainda, que tal iniciativa liberará os policiais encarregados da escolta do réu do presídio até o fórum, ensejando economia, haja vista inexistir custos com tal procedimento e o combustível do veículo, bem como maior segurança na sociedade, já que presos não mais circularão pela ruas, evitandose fugas e conflitos armados.

Quanto à questão da melhoria da segurança pública com o sistema da videoconferência, o, à época, Governador do Estado de São Paulo, Geraldo Alckmin, aduziu que "com a redução dos deslocamentos dos detentos, diminuiremos automaticamente o risco de tentativas de resgate e a possibilidade de fugas". ${ }^{137}$

Observa-se, pelas justificativas apresentadas tanto no referido Projeto de Lei paulista, quanto no da Assembléia Legislativa do Estado do Rio de Janeiro, bem como pelos Tribunais de Justiça país afora, que os objetivos do interrogatório virtual podem ser classificados em três vertentes principais: uma econômica, outra atinente à segurança pública e, por fím, uma ligada à celeridade da prestação jurisdicional.

Importante ressaltar que tais Projetos de Lei, muito menos as Leis 11.819/05 e 4.554/05, especificam em quais circunstâncias e sob que condições seria possível ocorrer o interrogatório por videoconferência. A ausência de critérios mínimos para a feitura de tal ato levava a crer que, em qualquer caso, poderia ser realizado, trate-se de um preso comum ou de um extremamente perigoso.

\footnotetext{
${ }^{137}$ FIOREZE, Juliana.Videoconferência no Processo Penal Brasileiro: Interrogatório On-Line. Paraná: Juruá, 2008. p.286
} 
O interrogatório, como meio de defesa do réu no processo penal, está intimamente ligado aos princípios da ampla defesa, do contraditório e do devido processo legal, de modo que tiveram início questionamentos no Judiciário acerca da legalidade e constitucionalidade de tal método, o qual impede o contato do réu pessoalmente com o Juiz e com seu defensor, em violação aos mencionados princípios.

Além disso, elaborou-se questionamento acerca da possibilidade de leis estaduais disporem acerca de matéria processual penal, haja vista tal incumbência ser afeta à União, a qual detém competência privativa para legislar sobre matéria penal e processual penal, conforme o artigo 22, I, da Constituição Federal.

A matéria chegou ao Supremo Tribunal Federal por meio do Habeas Corpus $n^{\circ} 88.914$, impetrado pela Procuradoria Geral do Estado de São Paulo em favor de réu interrogado no próprio presídio pelo sistema da videoconferência. Aduziu a Procuradoria que tal prática viola o direito de presença do acusado, que é corolário da ampla defesa, do contraditório e do devido processo legal, bem como que não havia previsão no Código de Processo Penal para tal ato.

Em julgamento realizado no dia 14.08.2007, a Segunda Turma do Supremo Tribunal Federal, em voto da relatoria do Ministro Cezar Peluso, reconheceu a nulidade absoluta do interrogatório realizado por videoconferência tendo em vista que tal procedimento não está previsto em lei ${ }^{138}$, ferindo, portanto, o devido processo legal, bem como o direito de defesa do acusado:

\footnotetext{
${ }^{138}$ Outro argumento que embasou a nulidade do ato do interrogatório foi o fato de que não houve citação formal do acusado para a audiência, o qual foi tão somente instado a comparecer na sala do
} 
"Quando se impede o regular exercício da autodefesa, por obra de procedimento sequer previsto em lei tem-se agravada restrição à defesa penal enquanto incompatível com regramento contido no artigo $5^{\circ}, L V$, da Constituição da República, o que conduz a nulidade absoluta do processo, como tem reconhecido este tribunal, à vista de prejuízo ínsito ao descumprimento da forma procedimental adequada" ${ }^{139}$.

Portanto, a falta de atendimento às prescrições legais, que, à época do julgamento, previam a ida do juiz até o presídio para interrogar pessoalmente o réu, ou, na impossibilidade desta medida, recomendavam a condução do acusado para ser interrogado no fórum, violavam o procedimento previsto no Código de Processo Penal.

Todavia, em seu voto, o Ministro Cezar Peluso reconheceu que outros países já fazem uso da videoconferência, considerando-o um "mal necessário", passível de utilização caso previsto por ente competente para legislar acerca do tema, em circunstâncias limitadas.

Assentou, além disso, em obter dictum, que, ainda que houvesse previsão legal para a videoconferência "a decisão de fazê-lo não poderia deixar de ser suficientemente motivada, com demonstração plena de sua excepcional necessidade no caso concreto." 140

Com base na exposição realizada pelo Ministro acerca de alguns requisitos que deveriam ser observados para a viabilidade legal da implementação da videoconferência, vistos anteriormente, o Senador da República, Dr. Aloizio Mercadante, elaborou o Projeto de Lei nº 679, de

presídio no qual se encontrava acautelado. STF, $\mathrm{HC} \mathrm{n}^{\circ}$ 88.914, Rel. Ministro Cezar Peluso, Brasília, 14 ago. 2007.

${ }^{139}$ Ibid.

${ }^{140}$ Ibid. 
28.11.07 $7^{141}$, propondo alterações no Código de Processo Penal a fim de possibilitar o interrogatório do réu por intermédio deste sistema. ${ }^{142}$

Conforme dispõe o Projeto de Lei 679/07 a intenção é compatibilizar a redação deste com o entendimento sufragado pelo Supremo Tribunal Federal $^{143}$ no Habeas Corpus no $88.914 / 07$, o qual revelou, no voto do Ministro Cezar Peluzo, características que uma futura lei, que tratasse da matéria, deveria conter a fim de se adequar à ordem constitucional vigente.

Além da necessária fundamentação judicial, com base em circunstâncias previamente definidas em lei, o Senador Aluizio Mercadante esclarece que a regra deve ser a realização do interrogatório na presença do magistrado, vindo este a se deslocar para o presídio e que, em casos excepcionais, tal ato realize-se por intermédio da videoconferência.

\footnotetext{
${ }^{141}$ Cabe ressaltar que não se trata do primeiro Projeto de Lei, em âmbito federal, acerca do tema. Antes da iniciativa do Senador Aluizio Mercadante, já existiam as seguinte propostas em trâmite no Congresso Nacional: Projeto de Lei 1.233/99, do Deputado Luiz Antônio Fleury; Projeto de Lei 2.504/00, do Deputado Nelson Proença; Projeto de Lei 238/02, do Senador Romero Jucá; Projeto de Lei 248/02, do Senador Romeu Tuma; Projeto de Lei 1.334/03, do Deputado Carlos Sampaio. In FIOREZE, Juliana. Videoconferência no Processo Penal Brasileiro: Interrogatório On-Line. Paraná: Juruá, 2008. p. 247-249.

142 O projeto do Senador Aluizio Mercadante previa a alteração dos artigos $185, \S 1^{\circ}$ ao $\S 5^{\circ}, 203,212$ e $222, \S 1^{\circ}$ ao $\S 6^{\circ}$, todos do Código de Processo Penal Além disso, o projeto sugeria a ampliação da utilização da videoconferência no caso de oitiva de testemunha presa, e, também, a criação de regra que possibilitasse, mediante autorização do juiz, que o acusado preso acompanhasse a oitiva de testemunhas por meio de videoconferência. Disponível em: 〈www.senado.gov.br〉.

${ }^{143}$ Somente a título de observação, deve-se ter em vista que a decisão que influenciou o Senador Aluizio Mercadante a propor o presente Projeto de Lei foi proferida pela Segunda Turma, composta, na data do julgamento, pelos Ministros Cezar Peluzo, Gilmar Ferreira Mendes e Eros Roberto Grau, ausente o Ministro Joaquim Barbosa. Portanto, as características que o Ministro Cezar Peluzo faz alusão, para a validade de uma futura lei que viesse a tratar do tema, parece refletir uma opinião individual do Ministro e não entendimento de todo o Supremo Tribunal Federal. Tanto é assim que os Ministros Gilmar Mendes e Eros Grau, os quais votaram juntamente com o Ministro Cezar Peluzo, não apontaram nenhuma característica que uma futura lei deveria trazer em seu corpo ou mesmo concordaram com as listadas pelo Ministro Cezar Peluzo. Ao contrário, o Ministro Gilmar Mendes, com cautela, observa, acerca da videoconferência, que "não há lei a autorizar. Houvesse lei, certamente teríamos que discutir outras questões pontuadas no brilhantíssimo voto que sua excelência acaba de proferir. Toda esta questão relativa à conformação, nos termos em que nós entendemos o contraditório e a ampla defesa. Encontrar-se uma conformação adequada que faça esta possível prática do ponto de vista tecnológico compatível com a ordem constitucional.” STF, HC $\mathrm{n}^{\circ} 88.914$, Rel. Ministro Cezar Peluso, Brasília, 14 ago. 2007.
} 
Durante a tramitação da referida proposta legislativa, o Plenário do Supremo Tribunal Federal, em julgamento do Habeas Corpus $n^{\circ}$ 90.900, realizado no dia 30 de outubro de 2008, entendeu que a Lei 11.819/06, do Estado de São Paulo, anteriormente analisada neste trabalho, prevendo a realização de interrogatórios por videoconferência, era formalmente inconstitucional.

Na referida decisão, anulou-se o processo submetido à análise até o ato do interrogatório, sob o entendimento de que a matéria atinente à regulamentação da videoconferência no país era de cunho processual penal e não procedimental, inviabilizando, portanto, a tratativa do tema por meio de uma lei estadual.

$\mathrm{O}$ entendimento vencedor ${ }^{144}$ considerou que a Lei 11.819 violou o disposto no artigo 22, I, da Constituição Federal de 1988, invadindo, deste modo, competência privativa da União em legislar acerca de matéria processual penal.

O Ministro Carlos Alberto Menezes Direito, no referido julgamento, expressou o seguinte entendimento:

"a lei estadual viola flagrantemente a disciplina do artigo 22, inciso $I$, da Constituição da República" e, em complemento, aduziu que "a matéria é de processo e sendo de processo a União detém o monopólio, a exclusividade para estabelecer a disciplina legal na matéria". ${ }^{145}$

\footnotetext{
${ }^{144}$ Dos 10 Ministros presentes à sessão de julgamento, apenas a Ministra Ellen Gracie votou em sentido contrário, argumentando que a matéria, a seu ver, poderia ser tratada por meio de uma lei estadual, com base no artigo 24, XI, da Constituição Federal, haja vista tratar-se de tema referente a procedimento e não ao processo penal, de modo a não vislumbrar qualquer inconstitucionalidade formal na citada legislação. STF, HC nº 90.900, Rel. Ministra Ellen Gracie, 30 out. 2008 ${ }^{145}$ Ibid.
} 
Ressalte-se que o Plenário do Supremo Tribunal Federal declarou a inconstitucionalidade formal da norma, ou seja, entendeu que houve um vício no procedimento legislativo, já que ente da federação tratou de matéria alheia a de sua competência. Não se adentrou, portanto, ainda que alguns Ministros tenham manifestado, em obter dictum, algumas opiniões a respeito, no exame de um possível vício material da lei. ${ }^{146}$

Gustavo Henrique Righi Ivahy Badaró, em crítica tecida anteriormente à decisão do Supremo Tribunal Federal, já antevia a impossibilidade de lei estadual dispor acerca do interrogatório virtual, argumentando que tal matéria nem ao menos estava prevista no Código de Processo Penal, fato que geraria uma completa incongruência jurídica:

\begin{abstract}
"Nem se diga que se trata de hipótese de competência concorrente, e que o Estadomembro estaria apenas legislando, concorrentemente, sobre "procedimento em matéria processual" (CR, art. 24, inc. XI). Embora seja tormentosa e nem sempre clara a distinção entre processo e procedimento, é evidente que o Estado não pode criar um procedimento em relação a um instituto que, processualmente, não existe e não foi previsto. É evidente que, se o Código de Processo Penal não prevê o interrogatório nem a oitiva de testemunhas por videoconferência, não poderia o Estado disciplinar o procedimento do interrogatório e da oitiva de testemunhas por videoconferência!" 147
\end{abstract}

Em conclusão, o autor previa que a realização do interrogatório por meio da videoconferência ensejaria a nulidade absoluta do ato, o que acabou por acontecer, como visto, no julgamento do Habeas Corpus $\mathrm{n}^{\circ} 90.900$.

\footnotetext{
${ }^{146}$ Luís Roberto Barroso esclarece o significado do que vem a ser vício material, aduzindo que " $a$ inconstitucionalidade material expressa uma incompatibilidade de conteúdo, substantiva entre a lei ou ato normativo e a Constituição. Pode traduzir-se no confronto de uma regra constitucional - e.g., a fixação da remuneração de uma categoria de servidores públicos acima do limite constitucional (art. 37, XI) - ou com um princípio constitucional, como no caso de uma lei que restrinja ilegitimamente a participação de candidatos em concurso público, em razão do sexo ou idade (arts. $5^{\circ}$, caput, e $3^{\circ}, I V$ ), em desarmonia com o mandamento da isonomia”. In BARROSO, Luís Roberto. O Controle de Constitucionalidade no Direito Brasileiro - Exposição Sistemática da Doutrina e Análise Crítica da Jurisprudência. São Paulo: Saraiva, 2a ed, 2005. p.29.

${ }^{147}$ BADARÓ, Gustavo Henrique Righi Ivahy. A lei estadual n. 11.819, de 05/01/05, e o interrogatório por videoconferência: primeiras impressões. Disponível em: 〈www.ibccrim.com.br〉.
} 
Diante da decisão da Suprema Corte, e com receio de que outros casos semelhantes chegassem à sua análise, vindo a ser anulados com base na mesma fundamentação ${ }^{148}$, libertando outros acusados, foi necessário imprimir maior celeridade na tramitação do Projeto de Lei 679/07, de autoria do Senador Aluizio Mercadante, de modo a editar uma Lei Federal, o quanto antes, tratando do assunto, conforme exigência do Supremo Tribunal Federal.

Deste modo, o Projeto de Lei 679/07, em célere trâmite legislativo, originou a recente Lei 11.900/09 dispondo acerca do interrogatório do réu por intermédio da videoconferência no Código de Processo Penal.

Ressalte-se que, tendo em vista a edição da Lei 11.719/08, prevendo a audiência una no processo penal, o Senador Tasso Jereissati, relator do Projeto na Comissão de Constituição e Justiça do Senado, efetuou algumas alterações no projeto original a fim de adequá-lo à nova sistemática processual.

Veja-se a justificativa do Senador Tasso Jereissati:

\begin{abstract}
"Finalmente, tendo em vista a edição da Lei no 11.719, de 20 de junho de 2008, que prevê a instrução e julgamento em audiência única, nos termos da nova redação oferecida ao art. 400 do CPP, entendemos que algumas adaptações são necessárias para: a) garantir ao acusado o direito de acompanhar todos os atos da audiência única de instrução e julgamento; b) estabelecer que a juntada da carta precatória deva ser feita antes da referida audiência, que, por sua vez, não terá sua realização suspensa em caso de não-devolução da precatória, salvo em caso de comprovado prejuízo para uma das partes. Em suma, vale registrar mais uma vez que as alterações que ora propomos não desnaturam, senão aperfeiçoam o PLS $n^{\circ} 679$, de 2007. Dada a abrangência das modificações, entendemos por bem apresentar Substitutivo, que, como dito, pretende avançar na mesma direção da proposta original, com os incrementos que entendemos necessários." 149
\end{abstract}

\footnotetext{
${ }^{148}$ Conforme dados do governo de São Paulo, entre 2005 e novembro de 2008 foram realizados aproximadamente 3.641 interrogatórios à distância, fato que justificava o receio de anulação de mais casos e a libertação dos respectivos acusados. Depoimentos por videoconferência vão liberar policiais. Disponível em <www.saopaulo.sp.gov.br>.

${ }^{149}$ Disponível em: 〈www.senado.gov.br〉.
} 
As alterações mostram-se coerentes e necessárias já que a Lei 11.900/09 foi editada em um momento de reformas do Código de Processo Penal $^{150}$, todas estas elaboradas por uma Comissão especialmente designada para tal fim. Nesta situação, tal adequação da Lei 11.900 com a reforma do código era imprescindível, a fim de evitar romper a harmonia dos dispositivos legais.

Exposta a evolução do instituto em nosso direito até a edição da recente Lei $11.900 / 09$, a qual introduziu a possibilidade do interrogatório por videoconferência no processo penal brasileiro, passa-se a análise da discussão que permeia tal prática, apresentando-se as correntes que vislumbram o interrogatório virtual como algo benéfico e inovador na ordem jurídica, em contrapartida àquela que o refuta como violador de direitos de defesa do acusado, sendo, portanto, incompatível com os princípios do devido processo legal, contraditório e ampla defesa, todos de índole constitucional.

\footnotetext{
${ }^{150}$ Antes da Lei 11.900/09, o Código de Processo Penal havia sido recentemente alterado pelas Leis $11.689,11.690$ e 11.719 , todas do ano de 2008 .
} 


\section{POSICIONAMENTOS ACERCA DA VIDEOCONFERÊNCIA}

\section{1 - Argumentos favoráveis}

É grande o número daqueles que defendem a implementação da videoconferência em solo brasileiro. Apesar desse expressivo número que compõem tal corrente, é possível distinguir, ao menos, três argumentos que embasam as argumentações desse grupo, a fim de conferir uma justificativa plausível para o interrogatório à distância.

Inicialmente sustenta-se que o interrogatório por videoconferência operará efeitos benéficos na questão atinente à segurança pública.

O segundo argumento pauta-se em uma análise econômica do tema, firmando-se na convicção que tal prática reduzirá em grande proporção os gastos do Estado atinentes ao transporte do detento ao fórum, onde prestará seus esclarecimentos.

Por fim, preconiza-se que o interrogatório à distância imprimirá uma maior celeridade nos processos, agilizando sua tramitação e conferindo uma resposta estatal mais eficaz, fato que, segundo essa corrente, é de grande valia para os réus.

Listados os pontos principais levantados pelos defensores do interrogatório on-line, passa-se à análise dos argumentos em separado, de modo a expor de forma mais clara as questões que o cercam. 


\subsection{1 - A Questão da Segurança Pública}

É notório que vivemos em uma sociedade longe de alcançar níveis razoáveis de contenção da violência no espaço urbano, fato que, sem dúvida, gera uma insegurança generalizada da população e uma cobrança maior em relação às autoridades públicas, a fim de que desenvolvam uma estratégia para o combate ao problema.

Os noticiários e jornais, diariamente, informam como o crime vem se alastrando pelos diversos segmentos da sociedade, e como este se renova e conta cada vez mais com a participação daqueles que deveriam combatê-lo. ${ }^{151}$

A atuação criminosa, diante do, ainda, ineficaz combate ao crime, muitas vezes não encontra limites à sua frente, de modo a ensejar ações cada vez mais ousadas e violentas para sedimentar seu poder.

Diante desse quadro, insere-se a questão da utilização do interrogatório por videoconferência, que, teoricamente, auxiliaria para conferir uma sensação mais elevada de segurança na sociedade, bem como evitar fugas dos acusados, já que não haveria mais o deslocamento destes pelas ruas.

Nesse sentido, o Ministro Nilson Naves, do Superior Tribunal de Justiça, assim defende tal procedimento:

\footnotetext{
${ }^{151}$ Exemplo recente dessa participação dos agentes públicos no crime é o crescimento das milícias, grupos formados, em sua maioria, por policiais militares, bombeiros e agentes penitenciários, os quais atuam de modo violento em dadas comunidades, controlando o transporte alternativo da região, a comercialização de botijões de gás, o acesso à televisão à cabo, bem como cobrando "taxas" de comerciantes locais em troca de segurança aos respectivos estabelecimentos.
} 
"A meu ver, adotando-se esse canal de comunicação nos casos de prisioneiros de alta periculosidade, evitam-se os perigos à segurança da população provocados pelos riscos do deslocamento dos detentos. ${ }^{, 152}$

Ou seja: como não há esse transporte pelas ruas, afirma-se que aumentará a segurança da população, não a colocando em um estado apreensivo. ${ }^{153}$ Todavia, parece que o grande ponto da argumentação é no tocante à questão da fuga dos presos.

Diversos doutrinadores ressaltam que o transporte dos detentos enseja a possibilidade tanto de uma fuga individual, livrando-se o detento de sua escolta, quanto à ação de comparsas que pretendem resgatá-lo.

Fernando Capez, defensor do interrogatório à distância, afirma que a medida é necessária e benéfica, pois impede que policiais sejam "alvo" das ações de resgate perpetradas no caminho entre o presídio e o fórum, onde os acusados prestarão depoimento. ${ }^{154}$

No mesmo sentido, Luiz Flávio Gomes, ardoroso defensor da videoconferência no processo penal brasileiro, assim se manifesta acerca do tema:

\footnotetext{
"Ressalte-se, ainda, a questão da segurança. Pelo interrogatório virtual pode-se ouvir uma pessoa em qualquer parte do país, sem a necessidade de seu deslocamento, o que elimina os riscos que envolvem dada operação, tanto para o preso, que pode ser atacado enquanto transportado, como para a comunidade, que fica sujeita às conhecidas "operações resgates" e às fugas. ${ }^{155}$
}

\footnotetext{
${ }^{152}$ NAVES, Nilson. Direito e Tecnologia da Informação. Conselho da Justiça Federal-CJF. Brasília, dez. 2002. Disponível em: < http://www.cjf.jus.br/revista/numero19/artigo1.pdf>.

${ }^{153}$ FIOREZE, Juliana. Videoconferência no Processo Penal Brasileiro: Interrogatório On-Line. Paraná: Juruá, 2008. p. 166.

${ }^{154}$ CAPEZ, Fernando. Interrogatório por videoconferência. São Paulo: Complexo Jurídico Damásio de Jesus, jan. 2009. Disponível em: 〈www.damasio.com.br〉.

155 GOMES, Luiz Flávio. O Uso da Videoconferência na Justiça Brasileira. Disponível em: <www.lfg.com.br>. Artigo publicado em 15.03.2007.
} 
Reforçando a sustentação dessa argumentação, utiliza-se, comumente, como paradigma, o caso do traficante Luiz Fernando da Costa, o "Fernandinho Beira-Mar”, custodiado no presídio federal de Catanduvas, no Paraná.

Tendo em vista que é réu em ações penais que tramitam no Rio de Janeiro e no Espírito Santo, bem como pelo fato do Supremo Tribunal Federal já ter decidido que ele possui direito de assistir aos depoimentos de testemunhas em tais feitos, houve a necessidade de deslocamentos do acusado até os citados estados.

Esses deslocamentos, conforme sustentam os defensores do interrogatório à distância, geraram grande insegurança na população, com possibilidade de fuga e, provavelmente, represálias de facções criminosas inimigas. ${ }^{156}$

Nesse sentido, a Lei 11.900/09, que promoveu alterações no Código de Processo Penal, trouxe a possibilidade, excepcional, diga-se de passagem, da realização do interrogatório do acusado pelo sistema da videoconferência.

Todavia, como expresso no artigo $185, \S 2^{\circ}$, incisos I a IV, a medida só é possível caso colime atender a uma das finalidades listadas nos mencionados incisos, dentre as quais, encontra-se a prevenção de riscos à segurança pública:

"Art. 185, - O acusado que comparecer perante a autoridade judiciária, no curso do processo penal, será qualificado e interrogado na presença de seu defensor, constituído ou nomeado.

156 FIOREZE, Juliana. Videoconferência no Processo Penal Brasileiro: Interrogatório On-Line. Paraná: Juruá, 2008. p. 163-168. A autora cita, também, como exemplo para embasar seu argumento, um caso ocorrido no Rio de Janeiro, em 2005. Na ocasião, dois policiais civis e dois detentos foram assassinados durante uma ação criminosa que objetivava o resgate do traficante Marcélio de Souza Andrade, que prestaria depoimento no Fórum da Ilha do Governador. Ressalta a autora, todavia, que a escolta se mostrou ineficiente no presente caso, chegando ao ponto de as armas dos policias terem apresentado falhas no momento de combate à ação criminosa. 
$\S 2^{o}$ - Excepcionalmente, o juiz, por decisão fundamentada, de ofício ou a requerimento das partes, poderá realizar o interrogatório do réu preso por sistema de videoconferência ou outro recurso tecnológico de transmissão de sons e imagens em tempo real, desde que a medida seja necessária para atender a uma das seguintes finalidades:

$I V$ - prevenir risco à segurança pública, quando exista fundada suspeita de que o preso integre organização criminosa ou de que, por outra razão, possa fugir durante o deslocamento."

Resta claro, portanto, o acolhimento, por parte do Código de Processo Penal, do argumento da proteção à segurança pública. O legislador procurou, assim, interferir em uma questão extremamente complexa e delicada, que é a da segurança pública, com previsões que afastam, em alguns casos, os acusados das ruas.

Mais à frente, quando se tratar dos argumentos contrários à videoconferência, mostrar-se-á que uma mudança legislativa parece não ser a solução adequada à problemática tratada.

\subsection{2 - A Economia proporcionada aos Cofres Públicos}

Outro argumento, amplamente utilizado na defesa da videoconferência, é o do impacto positivo que a adoção de tal medida trará aos cofres públicos, beneficiando, assim, a sociedade como um todo.

Argumenta-se que haverá economia tanto no pagamento dos policiais, quanto no do combustível e manutenção técnica das viaturas responsáveis pelo transporte dos acusados até o fórum.

O governo do estado de São Paulo estima que, somente no ano de 2008, os policiais foram mobilizados 100.859 vezes e as viaturas realizaram 54.842 
viagens, totalizando 5,4 milhões de quilômetros, na soma de todos os trajetos. ${ }^{157}$

Em um número total, foram efetuadas 66.283 escoltas de acusados, os quais foram levados à presença dos magistrados 165.474 vezes, gerando um gasto para os cofres do estado de $\mathrm{R} \$ 5,53$ milhões de reais. ${ }^{158}$

A doutrina defensora do interrogatório por videoconferência ressalta os gastos vultosos do estado com esse transporte, conforme crítica de Fernando Capez:

"Não obstante as teses defensivas contrárias ao sistema de videoconferência, devese esclarecer que ele constitui um avanço incomparável na prática forense. Sabemos que são gastos, pelo Estado, milhões de reais mensais com despesas de escolta para interrogatórios de réus presos $" 159$

O referido doutrinador conclui seu raciocínio afirmando que "o Estado economizará com escolta, já que não haverá contingente de policiais à disposição, com combustível e refeição aos presos. ${ }^{160}$

No mesmo sentido, Wadih Damous, presidente do Conselho Seccional da Ordem dos Advogados do Brasil no Estado do Rio de Janeiro, reconhece o benefício à economia no uso do interrogatório por videoconferência, ressaltando, além disso, a questão da segurança proporcionada pelo sistema. ${ }^{161}$

157 Videoconferência faz Estado economizar $R \$ 6$ milhões por ano. Disponível em <www.saopaulo.sp.gov.br>.

${ }^{158}$ Ibid.

${ }^{159}$ CAPEZ, Fernando. Interrogatório por videoconferência. São Paulo: Complexo Jurídico Damásio de Jesus, jan. 2009. Disponível em: 〈www.damasio.com.br〉.

${ }^{160}$ Ibid.

${ }^{161}$ OAB aceita videoconferência. Disponível em <www.oab-rj.org.br〉. Importante ressaltar que, em reunião ocorrida no dia 01.02.2009, o Conselho Federal da Ordem dos Advogados do Brasil, decidiu por não questionar a constitucionalidade da Lei 11.900/09, entendendo que a legislação está em conformidade com os dispositivos e princípios da Constituição Federal de 1988. 
Além da Ordem dos Advogados do Brasil, a Associação dos Juízes Federais do Brasil - AJUFE - aprova o uso da videoconferência ${ }^{162}$, ressaltando os enormes gastos com o deslocamento de presos, que, em muitas ocasiões, estão em estados diferentes dos quais o processo tramita. Em defesa da prática, assim se manifesta a Associação:

“(...) é relevante lembrar o alto custo do transporte desses presos de alta periculosidade, que, não raro, são levados para presídios de segurança máxima, localizados em local afastado dos grandes centros urbanos e, em determinados casos, em outros estados, como nos de presos sujeitos à jurisdição federal." 163

Sustenta-se que já que tais gastos não mais serão necessários, as verbas destinadas a tal finalidade poderão ser afetadas a outras áreas como, por exemplo, saúde e educação, de modo que as referidas quantias seriam melhor empregadas .

Outrossim, policiais deslocados para efetuar escoltas seriam remanejados para outras áreas, proporcionando um acréscimo à segurança pública, já que realocados para outras tarefas de maior interesse social.

A tais deslocamentos dos acusados do presídio ao fórum e seu retorno ao respectivo estabelecimento prisional, cunhou-se a expressão "turismo judiciário" ${ }^{164}$, amplamente utilizada pelos defensores da videoconferência, na medida em que consideram um atentado ao dinheiro público e, portanto, à sociedade, tal permissão.

\footnotetext{
${ }^{162}$ Admite a Associação, entretanto, que o sistema deve ser utilizado tão somente para presos de alta periculosidade, não sendo, portanto, uma regra.

${ }^{163}$ Ajufe defende interrogatório por meio de videoconferência. Disponível em 〈www.ajufe.org.br $\rangle$.

${ }^{164}$ A expressão nasceu na Itália, há 14 anos, quando, diante de revoltas e de um grande clamor social no combate à máfia Cosa Nostra, operaram-se diversas mudanças na política, bem como na legislação italiana de combate ao crime organizado. MAIEROVITHC, Walter. Crime organizado. Turismo Judiciário no Brasil. Disponível em <www.ibgf.org.br>
} 
Resumindo os interesses econômicos que norteiam a prática do interrogatório à distância, Juliana Fioreze tece as seguintes observações:

\begin{abstract}
"Logo, na conjuntura caótica e atual, em que a violência e explosão da criminalidade são uma constante e o Estado está falido, não há motivos jurídicos ou econômicos a justificarem a resistência ao novo interrogatório. Qualquer tipo de reforço financeiro é bem- vindo. É o caso, já que se evita o envio de cartas precatórias, ofícios, requisições, desburocratizando e barateando a via processual. É mais do que isso. $O$ aumento do efetivo de polícia ostensiva sem qualquer custo adicional, evitando fuga de presos durante as escoltas, economizando gasolina das viaturas, aeroplanos e embarcações policiais, é algo que não pode ser desconsiderado." 165
\end{abstract}

A autora, como se observa, confere grande importância à questão econômica, entendendo que a economia dos gastos repercutirá socialmente de modo benéfico, reforçando o caixa governamental e a ampliação do policiamento ostensivo nas ruas.

\title{
6.1.3 - Celeridade Processual e Respeito aos Direitos do Acusado
}

É muito propalada a idéia de que a utilização da videoconferência irá imprimir maior celeridade aos processos, pois funcionará na sua desburocratização, bem como a de que não representa qualquer perigo de violação aos direitos fundamentais do acusado.

No tocante à maior celeridade, encontram-se afirmações de que a prática, quando adotada, evitará o envio de ofícios, de requisições aos diretores de presídio para que o acusado compareça em juízo, bem como a remessa de cartas precatórias para oitiva de presos em outras localidades. Além disso, economizar-se-ia papel e os serviços dos funcionários das varas criminais.

165 FIOREZE, Juliana. Videoconferência no Processo Penal Brasileiro: Interrogatório On-Line. Paraná: Juruá, 2008. p.175. 
Além disso, a desnecessidade do transporte do acusado traria uma maior agilidade ao feito, já que evitaria o adiamento da oitiva pelo não comparecimento, o que repercutiria favoravelmente ao réu.

Recentemente, em 26.03.2009, o Tribunal de Justiça do Distrito Federal e Territórios utilizou, pela primeira vez, o sistema da videoconferência, com base na Lei 11.900/09. O Presidente deste Tribunal, Desembargador Nívio Gonçalves, afirmou que a videoconferência traz diversas vantagens, pontuando a maior celeridade na prestação jurisdicional e eficiência dos atos processuais como exemplos. ${ }^{166}$

Ademais, sustenta-se que tal modelo de interrogatório não suprime as garantias constitucionais do réu como a ampla defesa e o contraditório, bem como não mitiga a publicidade do ato.

Primeiramente, no tocante à questão da violação à publicidade do ato, deve-se ter em conta que a publicidade dos processos que tramitam no judiciário - e também nos outros poderes - é da essência do regime democrático, legitimando suas decisões, e mostra-se em consonância com o sistema acusatório de processo penal. ${ }^{167}$

Como já visto, a publicidade nos julgamentos atua na maior garantia de imparcialidade dos magistrados, sendo possível qualquer cidadão, caso não se

\footnotetext{
166 Presidente do STF participa de $1^{a}$ audiência por videoconferência realizada pelo TJDFT. Disponível em <www.stf.jus.br>. O Ministro e Presidente do Supremo Tribunal Federal, Ministro Gilmar Mendes, esteve presente na referida cerimônia do Tribunal do Distrito Federal e, apesar de não adentrar em nenhuma análise profunda do instituto, ressaltou que o uso da informática é necessário para que "possamos ter uma justiça mais digna de nossos tempos; uma justiça mais célere e ao mesmo tempo mais segura".

167 A Constituição Federal de 1988, em seu artigo 93, inciso IX, dispõe acerca da publicidade dos atos processuais e o artigo $5^{\circ}$, inciso LX, assevera que a mesma só poderá ser restringida quando a defesa da intimidade ou o interesse social o exigirem. No mesmo sentido, dispondo acerca da necessidade da publicidade e da possibilidade de sua restrição em dados casos, temos o artigo 792, caput e $\S 1^{\circ}$, respectivamente, ambos do Código de Processo Penal.
} 
trate de processo protegido pelo sigilo, adentrar as salas de audiência e o plenário do Tribunal do Júri para assistir aos interrogatórios e demais atos processuais.

Conforme opinião de Juliana Fioreze, a oitiva do acusado no presídio, por via do sistema da videoconferência, não mitigará a publicidade do ato do interrogatório:

"A alegada falta de publicidade do ato, por vezes erigida como um dos óbices do interrogatório on-line, não é de ser considerada. Com a moderna tecnologia milhares e milhares de pessoas podem assistir ao ato simultaneamente, como de resto inúmeros atos são assistidos em nível mundial, simultaneamente, via internet, assegurando-se, deste modo, o princípio da publicidade geral e o controle social sobre os atos do Poder Judiciário, ampliando-se o acesso à informação." 168

Deste modo, democratiza-se o acesso à informação, potencializando o princípio da publicidade, que tem seus limites estendidos, preservando-se os dispositivos constitucionais que tratam da matéria. ${ }^{169}$

Além dessa questão da publicidade, argumenta-se que o direito ao contraditório e ampla defesa do réu, bem como o direito de ser interrogado na presença do juiz, não sofrerão violações, já que o acusado poderá exercer suas faculdades normalmente, ainda que por meio da videoconferência.

Aduz-se que, ainda que on-line, todas as determinações legais atinentes ao interrogatório são observadas, garantindo-se a ampla defesa e o contraditório. Existe a presença das partes, o magistrado informa ao réu do

\footnotetext{
168 FIOREZE, Juliana. Videoconferência no Processo Penal Brasileiro: Interrogatório On-Line. Paraná: Juruá, 2008. p. 226-227.

169 Ibid. p. 226-227. Embasando seu argumento com um exemplo prático, o qual demonstra a preocupação com o direito à informação, cita os julgamentos realizados no Supremo Tribunal Federal, os quais são transmitidos em tempo real para todo o Brasil, por intermédio da TV Justiça. Ademais, sustenta a autora que, embora realizado no presídio, o acesso será concedido a qualquer cidadão que queria assistir o ato. Ibid. 128.
} 
direito ao silêncio, lê-se a denúncia oferecida em face do acusado, são realizadas as perguntas em suas duas fases (pessoa do acusado e fatos), bem como as partes participam do ato formulando perguntas a fim de elucidar a verdade. $^{170}$

Ressalta-se, porém, que diplomas internacionais como o Pacto Internacional sobre Direitos Civis e Políticos ${ }^{171}$, de 1966 e a Convenção Americana sobre Direito Humanos ${ }^{172}$, de 1969, amplamente conhecida como Pacto de São José da Costa Rica, tratam do direito de estar presente durante os atos processuais.

Todavia, sustenta-se que o direito de presença pode ser garantido tanto com a presença física, bem como com a utilização dos modernos meio de comunicação, desde que assegurados todos os direitos e garantias do acusado.

Ademais, aduz-se que tais tratados, datados da década de 1960, não poderiam ter previsto o uso da videoconferência, já que, à época, a tecnologia ainda era incipiente e ainda caminhava para avanços, de modo que a videoconferência não era utilizada. ${ }^{173}$

Por outro lado, como argumento ao uso da videoconferência no Brasil, afirma-se que o país já promulgou, e estão em vigência em nossa ordem jurídica, algumas convenções internacionais, as quais, dentre outras questões criminais, tratam da videoconferência, prevendo sua utilização. Assim, a medida estaria amparada não só na legislação interna, mas também em

\footnotetext{
${ }_{1710}^{170}$ Ibid. p. 198.

${ }^{171}$ No artigo 14.3.d assim encontramos disposto: "Toda pessoa acusada terá direito (...) a estar presente no julgamento."

${ }^{172}$ No artigo 8.2 "d" e "f", respectivamente, assim encontramos: "direito do acusado defender-se pessoalmente"; "direito de inquirir as testemunhas presentes".

${ }_{173}$ FIOREZE, Juliana. Videoconferência no Processo Penal Brasileiro: Interrogatório On-Line. Paraná: Juruá, 2008. p. 197.
} 
convenções internacionais, que, como foram incorporadas à ordem interna, devem ser respeitadas e observadas.

Nesse sentido, frisando que a videoconferência possui o amparo de convenções internacionais promulgadas na ordem interna, explicitando-as, temos a observação de Carlos Roberto Siqueira Castro:

"Essa modalidade de interrogatório obedece aos reclamos do ordenamento jurídico internacional. Tanto a Convenção das Nações Unidas contra o Crime Organizado Transnacional (Convenção de Palermo), quanto a Convenção das Nações Unidas contra a Corrupção (Convenção de Mérida) e o Estatuto de Roma do Tribunal Penal Internacional, todos promulgados pelo Brasil, prevêem a videoconferência. Além ${ }_{174}$ disso, trata-se de técnica amplamente utilizada no âmbito do Direito Comparado. "

Entende o referido autor que se trata de uma medida excepcional plenamente viável e que a Lei 11.900/09 prevê as garantias do acusado (como, por exemplo, a entrevista prévia com o defensor e a comunicação reservada entre advogado e cliente durante o ato), de modo que há uma reprodução fiel das circunstâncias de um interrogatório ao vivo. Ademais, ressalta que, até o momento, inexiste pronunciamento de qualquer Corte Internacional de Direitos Humanos no sentido de que o interrogatório on-line, por si só, viola direitos e garantias do acusado. ${ }^{175}$

Aduz-se que sempre deverá existir um funcionário da justiça na sala do presídio, local onde será realizado o interrogatório, de modo a zelar pela publicidade do ato.Ademais, deverá existir um canal de comunicação privado,

\footnotetext{
${ }^{174}$ CASTRO, Carlos Roberto Siqueira. Resistência ao uso de novas tecnologias não se justifica. Tribuna do Advogado. Seccional da Ordem dos Advogados do Brasil no Rio de Janeiro. Ano XXXVI, março de 2009, n 447, p. 19.

${ }^{175}$ Ibid. p. 19.
} 
a fim de que o acusado se comunique com o seu advogado nos momentos que desejar. $^{176}$

Por outro lado, defende-se que a qualidade das transmissões de som e imagem garantem ao juiz a fiel observação de todas as reações, manifestações e emoções do réu, preservando-se, destarte, o contato visual e auditivo que deve ocorrer entre o magistrado e o acusado.

Nesse sentido, transcrevem-se as observações de Fernando Capez:

"o avanço da tecnologia é tamanho, de modo que não haverá prejuízo aos presos, dada a qualidade do som e da imagem do sistema de videoconferência, trazendo ao Juiz os mesmos subsídios que a presença física proporcionaria para a formação de sua convicção; e, o mais importante, as garantias individuais deles serão resguardadas por membros do MP, da Magistratura, pela $O A B$ e demais pessoas envolvidas nessa operação." 177

Afirma-se, portanto, que, apesar de não existir um contato pessoal, físico, com o magistrado da causa, este, diante do avanço tecnológico, poderá observar as reações dos acusados durante a inquirição sem perda da qualidade dessa percepção. ${ }^{178}$

Por fim, sustenta-se que o sistema processual brasileiro não pode permanecer alheio às inovações tecnológicas e, desde que preservadas as garantias processuais e constitucionais do acusado, a videoconferência deve ser

\footnotetext{
${ }^{176}$ O Tribunal de Justiça do Distrito Federal e Territórios, por exemplo, implantou uma cabine fechada com telefone para que os advogados que acompanham a audiência possam falar com seus clientes. $\mathrm{O}$ aparelho possui sistema de criptografia para garantir a privacidade e o sigilo na comunicação realizada. Presidente do STF participa de $1^{a}$ audiência por videoconferência realizada pelo TJDFT. Disponível em 〈www.stf.jus.br>.

${ }_{177}$ CAPEZ, Fernando. Interrogatório por videoconferência. Disponível em: 〈www.damasio.com.br〉.

${ }^{178}$ Ronaldo Batista Pinto, em crítica a essa necessidade de o réu estar no mesmo ambiente físico com o juiz, assim se manifesta: "não se tem notícia de interrogatório no qual o juiz tenha feito consignar que, ao formular determinada pergunta, viu-se o réu acometido de intenso rubor facial ou de tremor nas mãos (...) essa espécie de constatação viria carregada por tamanho subjetivismo, que a tornaria incapaz de conter algum valor probatório ou de prestar-se como elemento de defesa em favor do réu.”. Interrogatório on-line ou virtual. Constitucionalidade do ato e vantagens em sua aplicação. Disponível em <www.jusnavegandi.com.br>.
} 
utilizada, a fim de conferir uma prestação jurisdicional mais eficiente e célere, trazendo economia aos cofres públicos e uma possibilidade de redirecionamento dos gastos outrora efetuados, bem como garantindo uma maior segurança à sociedade.

\section{2 - POSICIONAMENTO CONTRÁRIO À VIDEOCONFERÊNCIA}

\subsection{1 - A VIOLAÇÃO AOS PRINCÍPIOS CONSTITUCIONAIS}

Demonstrados os pontos principais de argumentação dos defensores da videoconferência, passa-se, agora, a análise da tese contrária, a qual entende incabível a adoção de tal tecnologia no interrogatório dos acusados.

Inicialmente, observe-se que o interrogatório por videoconferência obteve amplo acolhimento tanto na mídia como na comunidade jurídica. Como visto, taxa-se como absurdo e incompreensível os vultosos gastos com o transporte de presos, entendendo-se que tais quantias poderiam ter destinação mais apropriada. Ademais, defende-se que o transporte dos detentos configura verdadeiro "turismo judiciário", comparando-se a ida ao fórum como um passeio e uma benesse a tais agentes, fato que influencia, de igual modo, na celeridade dos feitos.

Inicialmente, deve-se ter em vista que o transporte do acusado até o Tribunal, para ser interrogado na presença do magistrado que o julgará futuramente, momento em que poderá exercer sua autodefesa e manter contato com o seu julgador, podendo trazer elementos mais concretos para a formação 
de seu convencimento, não se configura como um favor ou benesse, mas sim como um direito.

Referido direito é extraído do artigo 399, § $1^{\text {º }}$, do Código de Processo Penal, alterado pela reforma da Lei 11.719/08, dispondo que "o acusado será requisitado para comparecer ao interrogatório, devendo o poder público providenciar sua apresentação." Ou seja: inicialmente, cabe ao Poder Público atender ao dispositivo e assegurar o direito do preso de ser interrogado na presença do juiz.

Além disso, para o réu preso, se aplica, ainda, o disposto no artigo 185, $\S 1^{\mathrm{o}}$, o qual dispõe que:

"o interrogatório do réu preso será realizado, em sala própria, no estabelecimento em que estiver recolhido, desde que estejam garantidas a segurança do juiz, do membro do Ministério Público e dos auxiliares bem como a presença do defensor" 179.

Na opinião de Paulo Rangel, levando-se em conta a realidade brasileira, referida disposição é verdadeira letra morta, na medida em que nenhum presídio oferece a segurança adequada para os participantes do ato. ${ }^{180}$

Com o advento da Lei 11.900/09, regulamentando o interrogatório por videoconferência no Processo Penal Brasileiro, admitiu-se, em caráter excepcional, e por decisão fundamentada do magistrado, o uso de tal

\footnotetext{
${ }^{179}$ Luiz Flávio Borges D’Urso, tratando do referido dispositivo legal, entende que toda a discussão acerca da videoconferência estaria suplantada se tal dispositivo legal fosse cumprido: "A polêmica do interrogatório por videoconferência não precisaria existir - e o próprio mecanismo da videoconferência para interrogatório mostra-se desnecessário - se contássemos com a boa vontade do juiz em comparecer às unidades prisionais para ali realizar esse ato, sem risco à segurança pública, sem necessidade de escolta e sem despesas, quer no deslocamento do preso ou na implantação de aparelhos de videoconferência”. D’URSO, Luiz Flávio Borges. Lei da Videoconferência ameaça ampla defesa. Disponível em 〈www.conjur.com.br〉.

${ }^{180}$ RANGEL, Paulo. Direito Processual Penal. 16 a ed. Rio de Janeiro: Lumen Juris, 2009. p. 522.
} 
tecnologia para empreender o interrogatório do réu, desde que tal decisão se funde em um dos motivos elencados nos incisos do artigo 185, $\S 2^{\circ}$, do Código de Processo Penal. ${ }^{181}$ Como se trata de excepcionalidade, a regra é a do o transporte do réu ao fórum ou mesmo a ida do magistrado ao presídio.

Portanto, o direito de ser interrogado perante o magistrado está concretizado e garantido em nosso Código de Processo Penal. Tal garantia atua para a conformação de um processo justo, direito de todo acusado. Mais do que isso: tais garantias legitimam a própria jurisdição, conforme ensinamento de Antônio Magalhães Gomes Filho:

\begin{abstract}
"As garantias processuais, ao contrário do que muitas vezes se afirma, não constituem favores concedidos aos criminosos, nem instrumentos destinados a promover a impunidade, mas expressam, na verdade, valores fundamentais de civilidade que devem informar a aplicação jurisdicional do direito. São, antes de tudo, garantias da própria jurisdição e seu fator de legitimação."
\end{abstract}

$\mathrm{Na}$ mesma esteira de pensamento, entendendo que tais garantias conformam um processo justo ao acusado, longe de se tratar de benesses legais, reitera-se a lição de Maurício Zanoide de Moraes:

"O processo penal e mais justo não é o que pune mais, não é o que pune menos, somente o rico ou o pobre. O processo justo é aquele que pune, com todas as garantias e com maior eficiência, os culpados e não pune, talvez idealmente, os inocentes." 183

\footnotetext{
181 Artigo 185, § 20: "Excepcionalmente, o juiz, por decisão fundamentada, de ofício ou a requerimento das partes, poderá realizar o interrogatório do réu preso por sistema de videoconferência ou outro recurso tecnológico de transmissão de sons e imagens em tempo real, desde que a medida seja necessária para atender a uma das seguintes finalidades: I - prevenir risco à segurança pública, quando exista fundada suspeita de que o preso integre organização criminosa ou de que, por outra razão, possa fugir durante o deslocamento; II - viabilizar a participação do réu no referido ato processual, quando haja relevante dificuldade para seu comparecimento em juízo, por enfermidade ou outra circunstância pessoal; III - impedir a influência do réu no ânimo de testemunha ou da vítima, desde que não seja possível colher o depoimento destas por videoconferência, nos termos do art. 217 deste Código;IV - responder à gravíssima questão de ordem pública."

${ }^{182}$ GOMES FILHO, Antônio Magalhães. Garantismo à paulista: a propósito da videoconferência. Disponível em <www.ibccrim.com.br>.

${ }_{183}$ Código de Processo Penal: em busca de uma legislação efetiva. Notícia disponível em <www.stj.gov.br>.
} 
Ademais, tal direito encontra respaldo constitucional, sendo expressão e conteúdo dos princípios do Devido Processo Legal, Contraditório e da Ampla Defesa, disposto no artigo 5º, inciso LV, da Constituição Federal de 1988.

Como já visto, do Princípio do Devido Processo Legal, o qual contém a idéia de um processo justo, que deve desenrolar-se em atenção e respeito às regras legais e com a estrita observância das garantias e princípios aplicáveis ao processo, advém, como corolário, a necessidade de uma defesa ampla e do contraditório no trâmite processual. Esse, o sentido processual do Princípio do Devido Processo Legal.

Além disso, há o sentido substancial ou material de tal princípio, determinando que todos os atos do poder público devem ser elaborados observando a razoabilidade e a proporcionalidade de suas prescrições. Assim, as leis devem guardar razoabilidade, senso de justiça e enquadramento nas preceituações constitucionais, não devendo haver limitação aos direitos fundamentais do indivíduo sem que haja justo motivo. ${ }^{184}$

Luis Gustavo Grandinetti observa que as restrições aos direitos fundamentais, além de possuírem expressa previsão legal, devem ser determinadas, motivadamente, por um órgão investido de jurisdição. Além disso, assenta que devem ser observadas a idoneidade, necessidade e proporcionalidade em sentido estrito da medida, assim se manifestando acerca desses três últimos requisitos:

"O primeiro constitui-se no exame de a medida constritiva processual ter ou não relação de causalidade ao fim pretendido, ou seja, ser idônea, apta, para atingir aquele fim. A necessidade, também compreendida como intervenção mínima, é a

${ }^{184}$ GOMES, Luiz Flávio; PIOVESAN, Flávia. O Sistema Interamericano de Proteção dos direitos humanos e o direito brasileiro. São Paulo: Revista dos Tribunais, 2000, p.186 apud FIOREZE, Juliana. Videoconferência no Processo Penal Brasileiro: Interrogatório On-Line. Paraná: Juruá, 2008. p. 183. 
adequação do grau de eficácia das medidas. E, por último, a proporcionalidade em sentido estrito é o exame do confronto direito entre interesses individuais e estatais, a fim de estabelecer se é razoável exigir-se o sacrifício do interesse individual em nome do interesse coletivo." 185

Deste modo, padece de vício grave a Lei 11.900/09 já que limita o direito de presença do acusado perante o juiz de sua causa, mitigando sua possibilidade de ampla defesa e contraditório de modo significativo, não convencendo os motivos que inspiraram a novel redação do artigo $185, \S 2^{\circ}$, e seus respectivos incisos, como será melhor abordado adiante. Portanto, tais prescrições legais não parecem guardar razoabilidade no que almejam, pois atingem um direito do acusado em sua essência e, concomitantemente, não apresentam resultados práticos que beneficiem efetivamente a coletividade, de modo a justificar a restrição a direitos fundamentais. Viola, assim, o devido processo legal em seu viés substancial.

Passa-se a analisar, agora, as repercussões do interrogatório on-line nos princípios da ampla defesa e do contraditório, demonstrando-se que, inserta dentre tais princípios, está a garantia de estar presente, fisicamente e não virtualmente, no ato do interrogatório.

Tais princípios, ainda que muitas vezes tratados separadamente, devem ser vistos com complementares, na medida em que é efetivamente do contraditório que nasce o exercício da defesa, e é essa que garante aquele. Deste modo, a ampla defesa garantiria o contraditório.

Como visto, o princípio do contraditório garante ao acusado a ciência de todos os atos processuais e a participação no processo a fim de influir de

185 GRANDINETTI, Luis Gustavo. O Processo Penal em Face da Constituição - Princípios Constitucionais do Processo Penal. $2^{\mathrm{a}}$ ed. Rio de Janeiro: Lumen Juris, 1998. p. 74. 
maneira plena no convencimento judicial. É a bilateralidade da audiência, donde se extrai que todos os atos devem ser praticados na presença das partes e a essas é facultado se manifestar sobre os mesmos, contraditando-os.

Joaquim Canuto Mendes de Almeida, em síntese, define o contraditório como a "ciência bilateral dos atos e termos processuais e a possibilidade de contrariá-los.",186

Daí porque resta difícil aceitar a ausência do acusado em audiência, permanecendo este no presídio, afastado, pois, de todo o desenrolar da instrução probatória, exatamente no momento de seu interrogatório. Sua presença é, sim, indispensável, a fim de que exerça com plenitude sua defesa.

Ademais, registre-se que, com a mudança do Código de Processo Penal, implementou-se o sistema da audiência una, de modo que, teoricamente, todos os atos processuais deverão realizar-se em um único dia: testemunhos de acusação e defesa, depoimentos dos peritos, análise das provas, bem como o interrogatório do acusado. Assim, o interrogatório por videoconferência, afastando a presença física do réu, importa sua privação não só do ato do interrogatório, mas de toda a instrução criminal, de modo que, ao fim, desenrola-se o processo sem que o juiz e o órgão do Ministério Público conheçam o acusado, fato que se mostra evidentemente grave e que merece maiores reflexões.

Insurgindo-se contra tal prática, considerando-a inadequada e violadora do contraditório, Antônio Magalhães Gomes Filho assim se manifesta:

\footnotetext{
${ }^{186}$ ALMEIDA, Joaquim Canuto Mendes de. Princípios fundamentais do processo penal. São Paulo: Revista dos Tribunais, 1973. p . 107-108 apud FIOREZE, Juliana. Videoconferência no Processo Penal Brasileiro: Interrogatório On-Line. Paraná: Juruá, 2008. p. 191.
} 
"Processo, por definição, é atividade que se realiza em contraditório, ou seja, com a participação dos interessados no provimento final (Fazzalari). Por isso, não há como falar em processo penal sem a presença do maior interessado na decisão - o acusado - nos atos processuais, que assim são qualificados exatamente pela circunstância de serem realizados diante do juiz e com a intervenção das partes.Daí ser inviável, a menos que se considere o processo como simples encenação ou formalidade, a ouvida do preso como acusado, ou mesmo como testemunha em outro processo, sem que o mesmo esteja fisicamente presente ao ato processual correspondente. Por mais sofisticados que sejam os meios eletrônicos, somente a presença efetiva da audiência pode assegurar a comunicação entre os sujeitos processuais. Basta lembrar que até mesmo para aferir a sinceridade ou falsidade de uma declaração conta muito a percepção direta e imediata das reações do réu ou da testemunha." 187

Portanto, a presença física do acusado é indispensável no processo, que é realizado em seu interesse, buscando resguardar todas as suas garantias. Ademais, é direito seu tomar ciência, ao vivo, de tudo que ocorre e buscar influir nas impressões que o magistrado forma acerca do caso, por intermédio do interrogatório. Não há como aceitar que uma videoconferência, ainda que transmita imagens de alta definição, faça as vezes da presença física do réu, simulando algo que nunca se aproximará da realidade.

Assiste-se, com tal prática, que o acusado não poderá exercer o contraditório em uma intensidade e extensão desejável, como requer tal princípio, de modo a violá-lo e não garantir uma participação simétrica das partes no processo penal, já que a defesa, com o interrogatório on-line, perde muito da sua efetividade e poder de convencimento. É o princípio da paridade de armas ou par conditio, incluído na noção do princípio do contraditório. ${ }^{188}$

Deve-se ter em conta, e parece que muitas vezes os defensores dessa prática se esquecem disso, que estamos no âmbito de um processo criminal e não cível ou trabalhista. O simples início de um processo criminal, como em

\footnotetext{
${ }^{187}$ GOMES FILHO, Antônio Magalhães. Garantismo à paulista: a propósito da videoconferência. Disponível em: 〈www.ibccrim.com>.

188 OLIVEIRA, Eugênio Pacelli de. Curso de Processo Penal. 10 $0^{\mathrm{a}}$ ed. Rio de Janeiro: Lumen Juris, 2008. p. 31.
} 
nenhum outro ramo processual, já confere ao acusado um caráter estigmatizante perante a sociedade, passando este a ser visto com "outros olhos". A liberdade, bem supremo e garantido constitucionalmente, de um cidadão está em jogo e, nesse momento, não há como argumentar que questões relativas à segurança, à economia ou celeridade prevaleçam. É necessária a presença de qualquer acusado em juízo.

Com a consagração do princípio do contraditório, abrindo-se a possibilidade do réu tomar ciência dos atos e de contraditar todos os fatos trazidos ao feito, é necessário analisar o princípio da ampla defesa, decorrente daquele.

Tal princípio assegura à parte todos os meios disponíveis para efetivar uma defesa no caso concreto, a fim de refutar as acusações que pairam sobre si.

Como já visto, no princípio da ampla defesa está encartado o direito de autodefender-se (autodefesa) e a possibilidade de contar com uma defesa técnica que auxilie o acusado durante todo o trâmite processual.

O direito de defesa pessoal, diante de sua grande importância, está consagrado em diplomas internacionais, como por exemplo, o Pacto Internacional de Direitos Civis e Políticos (art. 14.3.d) ${ }^{189}$, bem como na Convenção Americana de Direitos Humanos, o denominado Pacto de São José da Costa Rica, (art.8.2). ${ }^{190}$

\footnotetext{
${ }^{189}$ Art. 14. "3- Toda pessoa acusada de um delito terá direito, em plena igualdade, a pelo menos às seguintes garantias: d) de estar presente no julgamento, ou de defender-se, pessoalmente ou por intermédio de defensor de sua escolha."

${ }^{190}$ Art.8. "2- Toda pessoa acusada de um delito tem direito a que se presuma sua inocência enquanto não se comprove legalmente sua culpa. Durante o processo, toda pessoa tem direito, em plena igualdade, às seguintes garantias: d) direito do acusado de defender-se pessoalmente ou de ser
} 
O interrogatório, como efetivo meio de defesa, é o ato no qual o réu poderá exercer de modo mais amplo possível seu direito de defesa, fornecendo sua versão dos fatos ao magistrado que, até o momento, não o conhecia. Assim, abre-se a oportunidade de influir no ânimo tanto do juiz e do membro do Ministério Público, quanto no dos jurados, quando o ato se realizar no Tribunal do Júri.

Note-se que as disposições relativas ao interrogatório vêm sendo aperfeiçoadas desde a Lei 10.792/2003, que, entre importantíssimas modificações, permitiu que as partes formulassem perguntas ao acusado, fato de extrema importância para a sua defesa. Ademais, a recente Lei 11.719/09 deslocou a posição do interrogatório, passando o mesmo a ser o último ato processual, proporcionando ao acusado uma maior análise das provas produzidas, a fim de melhor prestar suas declarações em juízo. Ou seja: o interrogatório, como ato de defesa que é, agora é realizado após toda a instrução probatória.

Logicamente, tais mudanças, conferindo uma feição de defesa ao interrogatório, mostram-se totalmente incompatíveis com a realização do ato sem a presença física do acusado. A Lei 11.900/09, permitindo o interrogatório por videoconferência, ao invés de incrementar o processo com evoluções tecnológicas benéficas, representa um retrocesso no tocante às garantias do acusado e o exercício de sua autodefesa, que só é realizada, de forma realmente ampla, na presença do magistrado, do membro do Ministério Público, bem como na presença de seu advogado.

assistido por um defensor de sua escolha e de comunicar-se, livremente e em particular, com seu defensor. FIOREZE, Juliana. Videoconferência no Processo Penal Brasileiro: Interrogatório On-Line. Paraná: Juruá, 2008. p. 195. 
Sob outro enfoque, mas também entendo a videoconferência como um retrocesso, gerando um juiz insensível, assim se manifesta Aury Lopes Júnior:

\begin{abstract}
"Se uma das maiores preocupações que temos hoje é com o resgate da subjetividade e do próprio sentimento no julgar (sentenciar = sententiando $=$ sentire), combatendo $o$ refúgio na generalidade da função $e$ o completo afastamento do eu, o interrogatório on-line é um imenso retrocesso civilizatório (na razão inversa ao avanço tecnológico)." 191
\end{abstract}

Por outro lado, a doutrina favorável ao interrogatório virtual afirma que, ainda que se realize por videoconferência, todas as garantias do acusado são mantidas e o procedimento legal é observado à risca: existe a presenças das partes (Defensores, Ministério Público ou Querelante); o magistrado explica ao réu o direito que possui de permanecer calado; a denúncia é lida; as perguntas são realizadas em suas duas fases (sobre a pessoa do acusado e sobre os fatos); as partes também podem formular perguntas. ${ }^{192}$

Realmente o procedimento legal é seguido à risca. Entretanto, a observância é meramente de ordem formal, reproduzindo a letra da lei.

O interrogatório, para realmente falarmos em um ato de defesa do acusado, não deve somente ser observado nesse viés formal, ou seja, de que o juiz faça perguntas, fale sobre o direito ao silêncio, etc. ${ }^{193} \mathrm{O}$ importante, e esse é o cerne da problemática, é o modo como o procedimento ocorre na prática, como é feita a aplicação dos ditames legais. Deve ser realizado de modo a realmente conferir uma chance do acusado expor sua versão, de maneira mais ampla possível e, seu isolamento, a quilômetros de distância da sala de

\footnotetext{
${ }^{191}$ JÚNIOR. Aury Lopes. O Interrogatório on-line no processo penal: entre a assepsia judiciária e o sexo virtual. Disponível em <www.ibccrim.com.br>.

${ }^{192}$ FIOREZE, Juliana. Videoconferência no Processo Penal Brasileiro: Interrogatório On-Line. Paraná: Juruá, 2008. p. 198.

${ }^{193}$ Juliana Fioreze, afirma que todas as garantias do acusado são observadas, já que: "todas as formalidades dos artigos 185 a 196 são cumpridas." Ibid. 200.
} 
audiência, somente opera a mitigação de tal direito, o qual fica obstado de ser exercido plenamente.

Deve-se ter em mente que o virtual não é o real.

Aury Lopes Júnior, entendendo que a videoconferência viola a ampla defesa do acusado, manifesta-se contrariamente a tal prática:

"O direito de defesa e do contraditório (incluindo o direito a audiência) são direitos fundamentais, cujo nível de observância reflete o avanço de um povo. Isso se mede, não pelo arsenal tecnológico utilizado, mas sim pelo nível de respeito ao valor dignidade humana. E o nível de civilidade alcançado exige que o processo penal seja um instrumento legitimante do poder, dotado de garantias mínimas, necessário para chegar-se a pena. É a visão de que o processo penal é um instrumento a serviço da máxima eficácia dos direitos e garantias fundamentais do acusado, de limitação do poder para obter o necessário respeito a esfera de dignidade do réu. Nessa linha, é absurdo suprimir-se o direito de ser ouvido por um juiz, que não pode ser substituído por um monitor de computador." 194

Há, ainda, a questão da manifestação do acusado, a qual estará restringida por falar para uma câmera, em um procedimento que não permite que suas declarações sejam expressas e recebidas pelo magistrado do modo como realmente deseja e como efetivamente ocorrem.

Nesse sentido, a lição de Luiz Flávio Borges D’Urso:

“Mas o prejuízo maior será para a comunicação do réu com o próprio magistrado. Falar para uma câmara já é um fator inibidor para a maioria das pessoas. Mas a capacidade de expressão e de comunicação sofrerá ainda o prejuízo de se encontrar o réu dentro do sistema carcerário, local naturalmente hostil.,"195

Alberto Silva Franco, analisando o tema, entende que o uso da videoconferência viola a ampla defesa do acusado, já que o contato do acusado com o magistrado da causa é de suma importância, revelando-se como um dos

\footnotetext{
${ }^{194}$ JÚNIOR. Aury Lopes. O Interrogatório on-line no processo penal: entre a assepsia judiciária e o sexo virtual. Disponível em <www.ibccrim.com.br>.

${ }^{195}$ D’URSO, Luiz Flávio Borges. Lei da Videoconferência ameaça ampla defesa. Disponível em <www.conjur.com.br>.
} 
fundamentais momentos do processo penal, de modo que não pode ser abolido. $^{196}$

Realmente há de se concordar, pelo menos nesse ponto, que nem todos são acostumados a falar para uma câmera, restando claro que não chegará ao juiz, ao promotor, e ao júri, a fala real do acusado. Certamente suas declarações estarão revestidas por um nervosismo, fato normal em um interrogatório, e aflorado com tal prática, de modo que se perderá toda a essência das suas declarações, sendo, portanto, indispensável sua presença física. $^{197}$

Além disso, há a questão da garantia da defesa técnica. Bem, como já analisado, o acusado deve ser acompanhado de um advogado, sendo impossível o processo sem a observância de tal garantia. Com a implementação da videoconferência resta difícil compatibilizá-la com a nova prática, já que o advogado não pode estar em dois locais ao mesmo tempo: ou fica na audiência, distante do réu, acompanhando todo o desenrolar do processo, formulando perguntas às testemunhas de defesa e acusação e atuando sempre em sua defesa; ou permanece com o acusado no presídio, prestando-lhe o auxílio e apoio de que necessita, de modo que não acompanhará a audiência, que agora é una, não podendo atuar de maneira efetiva, sendo somente uma imagem para os participantes que no fórum se encontram.

\footnotetext{
${ }^{196}$ FRANCO, Alberto Silva. Direito penal não resolve violência nem criminalidade. Disponível em <www.conjur.com.br>.

${ }^{197}$ Paulo Ramalho, Defensor Público atuante no Rio de Janeiro, tece duras críticas ao interrogatório por videoconferência, e, na questão atinente as manifestações do réu por intermédio desse sistema, assim se manifesta: "O "cliente" do interrogatório virtual, que raramente sabe ler e escrever, ao virar réu, será introduzido no mundo digital - e esta será sua única experiência digital, salvo a reincidência - e se sentirá inibido, acuado, menor, como já s sente diante das construções luxuosas, da toga e das pompas que cercam o exercício da jurisdição. In: RAMALHO, Paulo. Perversidade, imoralidade e discriminação. Tribuna do Advogado. Seccional da Ordem dos Advogados do Brasil no Rio de Janeiro. Ano XXXVI, Mar. 2009, nº 447. p. 19.
} 
O professor Sérgio Marcos de Moraes Pitombo, nesse sentido, questiona o local onde o defensor deverá se encontrar no momento do interrogatório:

"Como se irão atender às formalidades do interrogatório, se realizado à distância? Onde deverão estar o defensor do incriminado e o curador do menor? Junto ao juiz de Direito, ou ao lado do acusado? Se o defensor achar-se no estabelecimento prisional, não poderá consultar os autos do processo, da ação penal, obstando a que, séria e profissionalmente, oriente o increpado, antes do interrogatório." 198

Tanto se faça presente no fórum, quanto no presídio, sempre haverá uma perda, em menor ou maior grau. Resta ainda difícil a possibilidade de haver mais de um defensor, com o objetivo de, tanto na audiência, quanto no presídio, assistir ao réu de modo efetivo. Tal ônus da contratação de dois advogados não poderá recair sobre o acusado ${ }^{199}$ e tal fato mostra-se distante da realidade da Defensoria Pública, instituição de extrema importância no processo criminal, mas que ainda necessita de uma estruturação mais ampla e condizente com a importância de seu papel no acesso à justiça.

\subsection{2 - As questões da celeridade processual e da economia aos cofres estatais}

Inicialmente, deve-se ter em mente que não há direitos absolutos em nosso ordenamento, ainda que estes sejam de índole constitucional e inseridos

198 PITOMBO, Sérgio Marcos de Moraes. Interrogatório à Distância. Disponível em <www.ibccrim.com.br>. No mesmo sentido, vejam-se as indagações formuladas por Aury Lopes Júnior. In JÚNIOR, Aury Lopes. O Interrogatório On-Line no processo penal: entre a assepsia judiciária e o sexo virtual. Disponível em <www.ibccrim.com.br〉.

199 Por certo, réus mais abastados poderão contratar dois advogados, a fim de acompanharem a audiência, tanto no fórum, quanto no presídio. Resta saber o que farão os que não possuírem tal condição, não sendo possível haver tamanha desigualdade e disparidade de oportunidades na questão atinente à defesa. 
dentre aqueles alçados à categoria de fundamentais. ${ }^{200}$ Todavia, também é correto que essa mitigação de tais direitos, como a ampla defesa e o contraditório, só devem ocorrer quando se mostrem imperativos a interesses maiores, coerentes, razoáveis e indispensáveis à sociedade.

Por outro lado, não se nega a importância do incremento tecnológico no seio do judiciário, atendendo a questões de celeridade e desburocratização dos processos. O direito deve estar sempre aberto à recepção de novos institutos tecnológicos, aperfeiçoando-se e modernizando-se.

Todavia, não parece ser o interrogatório o ato mais indicado para a implementação de novas tecnologias, pois, nitidamente, como visto, impõem um ônus muito grande para o acusado, o qual vê seu direito de defesa substancialmente afetado e reduzido.

Não se deve elevar a suposta celeridade do processo a tal ponto, de modo que esta se revele mais importante do que a observância irrestrita dos preceitos e direitos de uma defesa adequada. O processo penal não dará respostas melhores, precisas ou mais justas com ritos mais céleres, haja vista não haver nenhum nexo de causalidade entre celeridade e a qualidade e justiça das decisões judiciais.

Ademais, observe-se que a Lei 11.719/08 modificou a parte dos procedimentos, com a revelada intenção de trazer maior celeridade aos mesmos, instituindo a audiência una, na qual todos os atos processuais serão realizados em um único dia. A celeridade, tão divulgada pelos defensores da

\footnotetext{
${ }^{200}$ SARMENTO, Daniel. Livres e Iguais - Estudos de Direito Constitucional. Rio de Janeiro: Lumen Juris, 2006. p. 69.
} 
videoconferência, já foi, portanto, atendida pela Reforma que vem sendo instituída no Código de Processo Penal.

O processo penal, nos casos em que possível realizar toda a instrução num único dia, será mais rápido. Não parece que a instrução criminal em $1^{\circ}$ grau seja a maior causa da morosidade do judiciário, já que os feitos, quando julgados em $1^{a}$ instância, notoriamente percorrem durante anos os tribunais de justiça e os tribunais superiores até o esgotamento de todos os recursos. ${ }^{201}$

Além disso, o argumento da maior economia não convence. Afirma-se, em defesa da videoconferência, que a diminuição dos transportes dos presos reduzirá os custos estatais.

Todavia, como se observa do artigo $185, \S 2^{\circ}$, do Código de Processo Penal, a videoconferência deverá ser usada em casos excepcionais, de modo a abranger a minoria dos casos, já que, como a própria lei dispõe, é uma medida de exceção. Então, indaga-se: que redução gigantesca será essa nos gastos estatais?

Ora, se por um lado não há o transporte de alguns presos ao fórum, de outro há a necessidade de equipar os estabelecimentos prisionais, bem como as salas de audiência, com os aparelhos necessários a realização da videoconferência. Poupa-se de um lado, mas, concomitantemente, despendemse consideráveis quantias com a nova tecnologia.

\footnotetext{
${ }^{201}$ Somente a título de observação, já que não se trata aqui de discutir as causas da morosidade do judiciário, o Ministério Público Federal, em recente levantamento, constatou que havia 729 apelações criminais, já prontas para serem incluídas em pauta, paradas há mais de 2 anos nos gabinetes dos desembargadores do Tribunal Regional Federal da $1^{\mathrm{a}}$ Região. Diante de tal fato, e com receio de que a prescrição atingisse tais feitos, foi editada resolução assinada pelos presidentes do Supremo Tribunal Federal e do Superior Tribunal de Justiça, respectivamente, a fim de tornar obrigatório o registro, na capa dos processos que tramitam nestas cortes, da data de prescrição dos crimes a serem analisados, evitando-se, deste modo, a extinção da punibilidade em decorrência da prescrição. Data de prescrição de crimes será obrigatória nos processos do STF e STJ. Disponível em <www.oglobo.com.br〉.
} 
No Estado de São Paulo, por exemplo, será investido R\$ 1,6 milhão (um milhão e seiscentos mil reais) a cada mês, para a implantação da videoconferência, em um total de $\mathrm{R}$ \$ 40,3 milhões nos próximos dois anos, com o intuito de equipar 50 novas salas com a nova tecnologia. ${ }^{202}$ No total, o Estado contará com 66 salas equipadas.

Tal custo, frise-se, se refere tão somente à instalação de todo aparato tecnológico. Cada sala equipada com a videoconferência, no cálculo realizado pelo governo paulista, consumirá cerca de $\mathrm{R} \$ 17.445$ (dezessete mil, quatrocentos e quarenta e cinco reais) por mês. Em um cálculo simples, multiplicando-se o número de salas que estarão equipadas (66 ao todo) pelo valor da manutenção de cada uma delas, chega-se ao valor de R $\$ 1.150 .370$ milhão (um milhão, cento e cinqüenta mil, trezentos e setenta reais). Por ano, somente em manutenção, serão gastos R\$ 13.804 .404 milhões (treze milhões, oitocentos e quatro mil, quatrocentos e quatro reais).

Ainda segundo o governo paulista, o transporte dos presos, no ano de 2008, alcançou quase seis milhões de reais. Tal número confirma que, apesar da videoconferência, os gastos tendem a aumentar, conforme demonstra o cálculo feito anteriormente. Anualmente, irá se gastar aproximadamente R\$ 13.804.404 (treze milhões, oitocentos e quatro mil, quatrocentos e quatro reais) milhões de reais somente com a manutenção das salas, sem contar os imprevistos e gastos adicionais que deverão ocorrer. Com a permanência do sistema de escoltas, transportando os acusados até os tribunais, serão gastos, aproximadamente, R 6 (seis milhões de reias) milhões.

${ }^{202}$ Justiça de SP terá 50 novas salas de videoconferência. Disponível em <www.saopaulo.sp.gov.br>. 
Parece, como se observa, haver uma contradição no argumento de que a videoconferência proporcionará considerável economia aos cofres públicos.

Além disso, conforme dispõe o Código de Processo Penal, tal tecnologia será usada excepcionalmente, abrangendo casos realmente estritamente necessários. Diante de tais fatos, constata-se que a implantação do sistema será por demais custosa ao Estado, a fim de atender casos realmente necessários, revestidos de excepcionalidade, a não ser, e esta é uma grande e perigosa questão, que o excepcional torne-se regra.

Ressalte-se, ainda, que diante da nova sistemática procedimental, a videoconferência deverá ser utilizada para o preso assistir a todo o desenrolar do processo, pois o interrogatório é o último ato processual, de modo que o acusado deverá conhecer o conteúdo dos atos anteriores, a fim de prestar declarações da melhor maneira possível. Questiona-se: Isso já estava nos planos e nas previsões dos governos estaduais e do federal? Tal prática não aumentará os custos, já que, provavelmente, a audiência não demorará 30 minutos, mas algumas horas? Será que realmente o dinheiro está sendo bem investido e direcionado de modo eficaz?

Conclui-se, portanto, que a instalação da prática, em detrimento de direitos do acusado, argumentando-se com a maior celeridade dos feitos e uma maior economia do governo, não se sustentam em bases sólidas, já que a questão da celeridade já foi tratada recentemente com a Lei 11.719/08 e a economia tão divulgada, como visto, pelo menos no Estado de São Paulo, não ocorrerá. 


\subsection{3 - Breves considerações acerca da questão da segurança pública na Lei 11.900/09}

Além disso, em conclusão, há a questão final da segurança pública.

A prevenção à segurança pública é um dos motivos, conforme o artigo 185, §2º , I, do Código de Processo Penal, que ensejam o interrogatório do acusado por videoconferência.

Busca-se com uma alteração legislativa mitigar um mal que está se alastrando em nossa sociedade, que é o problema da violência. Não parece, todavia, ser essa a melhor solução.

A violência e a insegurança se encontram presentes em qualquer local, espraiando-se por diversos setores sociais. Todavia, atribui-se um valor demasiadamente grande ao transporte dos acusados, como se fosse uma das maiores causas de violência social e do surgimento da sensação de medo da população, o que, sabe-se muito bem, não é a verdade.

Aury Lopes Júnior, em crítica a essa solução para uma parcela diminuta da violência urbana, aduz que, antes de qualquer debate sobre a questão, devese ter em conta que já vivemos em uma sociedade de riscos. ${ }^{203}$

Em igual linha de pensamento, Paulo Rangel tece semelhante observação:

\footnotetext{
${ }^{203}$ JÚNIOR, Aury Lopes. O Interrogatório On-Line no processo penal: entre a assepsia judiciária e o sexo virtual. Disponível em <www.ibccrim.com.br>.
} 
"O que é risco à segurança pública? Em cidades como o Rio de Janeiro e São Paulo o risco já existe pela própria natureza dos problemas que elas enfrentam, bem como nas grandes capitais, embora um cidadão carioca ou paulista possa se sentir seguro em sua cidade: segurança é uma questão de sensação."204

Há, é verdade, possibilidade de fuga de presos, de possíveis resgates, e isso não é só passível de ocorrer no transporte dos acusados, já que se observa, em muitas ocasiões, resgates e fugas dos próprios complexos penitenciários. Em alguns casos, coloca-se à vista o despreparo e descaso para com o sistema carcerário, haja vista a fuga ocorrer pela porta da frente do presídio. ${ }^{205}$

A videoconferência, portanto, não contribuirá efetivamente com a questão da segurança pública, já que esta não reside primordialmente no transporte dos presos. A segurança pública é uma questão complexa, que deve ser gerida com estratégia e ações inteligentes, por meio de atos do poder público não só visando os policiamentos ostensivos ou similares, mas atuando na questão da educação dos jovens, saúde, e solução de problemas tanto nas comunidades mais necessitadas, quanto nas classes mais abastadas. Nessas ações é que realmente o poder público deve concentrar esforços e despender tempo e dinheiro, devendo ser a meta principal a ser atingida.

O governo parece se desapegar de uma responsabilidade que é institucionalmente sua, qual seja, a de cuidar para que o transporte de acusados, quer sejam tidos como perigosos ou mesmo tendo cometidos crimes de maior reprovação social, seja realizado da melhor maneira possível, selecionando o número de policias necessários ou a melhor estratégia para a ida ao fórum. É sua função, a fim de atender um direito do acusado, que é o de participar de uma audiência que poderá tirar-lhe ou não sua liberdade.

\footnotetext{
${ }^{204}$ RANGEL, Paulo. Direito Processual Penal. $16^{\mathrm{a}}$ ed. Rio de Janeiro: Lumen Juris, 2009. p. 523.

${ }^{205}$ Tal alusão refere-se à recente fuga de Ricardo da Cruz, o denominado "Batman", integrante da milícia conhecida como "Liga da Justiça", o qual escapou do presídio Bangu VIII, onde se encontrava acautelado, pela porta da frente, sem necessidade de qualquer resgate ou perpetração de ato violento.
} 
Não é de bom grado haver essa segregação, baseando-se em uma pretensa prevenção da ordem pública, onde alguns casos serão enquadrados nos incisos do artigo $185, \S 2^{\circ}$, I a IV, e outros poderão ir acompanhar de perto sua audiência e prestar declarações perante o juiz da causa.

Além disso, apesar de não se tratar de um caso de segurança pública,veja-se que o inciso II dispõe que a videoconferência será realizada quando o réu encontrar-se enfermo ou por outra circunstância social.

Primeiramente, se o réu está enfermo, nem mesmo deveria participar do ato, quer seja indo pessoalmente ao fórum ou por videoconferência. Caso encontre-se acometido por alguma doença, deve se recuperar e quando ocorrer a sua reabilitação, aí sim, prestará declarações em juízo. Imagine-se a cena de um acusado acometido de uma grave enfermidade tendo que, ainda sim, prestar declarações ao juízo, responder questionamentos do membro do Ministério Público, do seu advogado, etc. ${ }^{206}$

Ademais, o uso da expressão "ou outra circunstância pessoal" não revela nenhum sentido prático, sendo extremamente aberta e vaga, sendo possível encaixar as mais diversas situações, a fim de justificar uma prática que, como o próprio artigo $185, \S 2^{\circ}$ alude, é excepcional.

O inciso IV, por sua vez, aduz que a videoconferência poderá ser utilizada para "responder à gravíssima questão de ordem pública".

\footnotetext{
${ }^{206}$ Além dessa questão, Paulo Rangel levanta o ponto de que dificilmente o Estado se prestará a ir a um hospital ou similar para realizar a videoconferência: "A questão é imaginar que o Estado irá disponibilizar uma sala de videoconferência no local onde o preso estiver para ouvi-lo. Imagine um réu hospitalizado por qualquer motivo e o juiz determinando que o oficial de justiça vá ao hospital com uma aparelhagem e sistema de software próprio para ouvi-lo. No Brasil isso vai ocorrer sim quando esse réu for um grande empresário ou um banqueiro, mas não o "Tício" ou seu comparsa "Caio". Isso chama-se ingenuidade ou cinismo." RANGEL, Paulo. Direito Processual Penal. $16^{\mathrm{a}} \mathrm{ed.}$ Rio de Janeiro: Lumen Juris, 2009. p. 525.
} 
O legislador utiliza expressão já conhecida e causadora de diversos debates na seara da prisão preventiva, já que um dos requisitos que ensejam a decretação desta segregação cautelar, conforme o artigo 312 do Código de Processo Penal, é a garantia da ordem pública, conceito extremamente vago. A fim de ilustrar o tema, necessária a transcrição da lição de Eugênio Pacelli:

"É tempo, então, de examinarmos da prisão preventiva para a garantia de ordem pública, tema dos mais controvertidos nos tribunais e mesmo na doutrina (...) A expressão garantia de ordem pública, todavia, é de dificílima definição. Pode prestar-se a justificar um perigoso controle da vida social, no ponto em se arrima na noção de ordem, e pública, sem qualquer referência ao que seja efetivamente desordem" $" 207$

O autor ressalta que apesar de os perigos de reiteração na conduta criminosa, acompanhada do exame acerca da gravidade do fato e de sua repercussão, serem usados por parte da jurisprudência para conceituar a expressão, o tema ainda é vacilante nos tribunais pátrios. Por fim, assevera que já houve tempos nos quais se defendia, já que se trata de uma expressão imprecisa, a prisão preventiva do acusado até mesmo para a proteção de sua integridade física, como se não fosse do Estado a responsabilidade pela atividade não jurisdicional de segurança pública.

Há, portanto, enorme dificuldade ${ }^{208}$, tanto no seio doutrinário quanto jurisprudencial, quanto a saber, afinal, quais situações ou fatos se enquadram na definição de "ordem pública".

Portanto, diante de sua porosidade, podendo abarcar as mais diversas situações, tal conceito mostra-se propenso a enquadrar uma infinidade de casos

\footnotetext{
${ }^{207}$ OLIVEIRA, Eugênio Pacelli de. Curso de Processo Penal. 10 $0^{\mathrm{a}}$ ed. Rio de Janeiro: Lumen Juris, 2008. p. 435.

${ }^{208}$ Há autores, como Julio Fabbrini Mirabete, que buscam delimitar ordem pública, afirmando que busca-se evitar a reiteração criminosa, bem como acautelar o meio social e a credibilidade de justiça. In MIRABETE, Júlio Fabbrini. Processo Penal. $2^{a}$ ed. São Paulo: Atlas S.A., 1992. p. 371.
} 
no sistema da videoconferência, havendo o perigo de uma medida que pretende ser excepcional virar regra, diante da conveniência e facilidade em não providenciar o transporte e a escolta a fim de conduzir o acusado ao seu interrogatório.

Neste sentido, advém a crítica de Paulo Ramalho:

"Todas as hipóteses de videoconferência (CPP, art. 185, $\$ 2^{\circ}$, com redação da Lei $n^{o}$ 11.900/09) revelam o propósito único de poupar esforços administrativos da máquina estatal, que se livra do dever de garantir segurança, transporte e acomodações, em relação aos personagens do processo, incluindo, obviamente, o acusado, personagem central" ${ }^{209}$.

Tal crítica só vem a reforçar a idéia de que o estado não pode se afastar de suas funções, dentre as quais a de zelar pela segurança pública. Assim, como aduz o Ministro Cezar Peluso, "política criminal não é tarefa que caiba ao Poder Judiciário, cuja função específica é "solucionar conflitos, tutelando a liberdade jurídica, e não socorrer o Poder Executivo em suas falhas e omissões". 210

No mesmo sentido, entendendo que a videoconferência não possui ligação com o processo, mas sim com questões de segurança pública, transcreve-se a lição de Paulo Rangel:

"O interrogatório por videoconferência é medida de caráter excepcional e nada tem a ver com o processo em si, mas sim com uma questão de segurança pública. Se o transporte do preso é dispendioso para o Estado e exige maior cautela dos agentes públicos isso não é questão processual a justificar alteração das regras de processo que garantem o direito de defesa, mas sim administrativa ligada à política de segurança pública do Estado não justificando adoção de medida extrema de

\footnotetext{
${ }^{209}$ RAMALHO, Paulo. Perversidade, imoralidade e discriminação. Tribuna do Advogado. Seccional da Ordem dos Advogados do Brasil no Rio de Janeiro. Ano XXXVI, Mar. 2009, no 447. p. 19.

210 STF, HC no 88.914, Rel. Ministro Cezar Peluso, Brasília, 14 ago. 2007. Disponível em <www.stf.jus.br>.
} 
videoconferência que afronte o devido processo legal e seus corolários (ampla defesa, contraditório, publicidade, juiz natural)". ${ }^{211}$

Aduz ainda o autor que as questões de segurança pública devem ser resolvidas na seara do direito administrativo, com a utilização do poder de polícia, estabelecendo medidas de coerção para a manutenção da paz e da tranquiilidade social das pessoas e não com a negação do exercício de direitos e garantias individuais fundamentais assegurados pela Constituição da República de 1988.

Portanto, observa-se que supostos benefícios concernentes à ordem pública, à economia, ou mesmo à celeridade processual, tão festejados pelos defensores do interrogatório virtual, não são capazes de suplantar as perdas que o interrogando sofrerá, tanto na possibilidade de autodefesa, quanto na atuação efetiva da defesa técnica.

A videoconferência, assim, não se mostra compatível com a estrutura e os princípios que norteiam o processo penal brasileiro, não sendo a área processual penal a mais apropriada para a sua implementação.

O processo penal, logicamente, não deve se fechar totalmente à inovações tecnológicas. Sem dúvida que não. Todavia, não é qualquer nova tecnologia, conjugada a um anseio social, que é passível de adentrar na sistemática processual penal, na medida em que viola direitos fundamentais dos acusados, esvaziando a atividade defensiva. Em conseqüência, revela-se, com o uso da videoconferência, uma total desarmonia com os preceitos do Estado Democrático de Direito.

${ }^{211}$ RANGEL, Paulo. Direito Processual Penal. $16^{\mathrm{a}}$ ed. Rio de Janeiro: Lumen Juris, 2009. p. 523. 


\section{CONSIDERAÇÕES FINAIS}

O objetivo deste estudo, conforme já assinalado, não foi o de esgotar todas as discussões e implicações que a temática do interrogatório por videoconferência faz nascer, mas, ao revés, trazer algumas das questões que parecem mais relevantes e que vêm sendo ardorosamente debatidas no cenário atual, mostrando como se sustentam as posições contrárias e favoráveis à medida.

Apesar de, numa análise apressada e superficial da questão, revelar-se uma medida de bom grado, já que traria uma economia aos cofres públicos, uma maior segurança social, evitando-se fugas e resgates, bem como maior celeridade aos feitos criminais, tal constatação, como visto, merece reflexões mais profundas, tendo como pano de fundo a análise de como a Lei 11.900/09 repercute nos direitos e garantias do acusado e na estrutura do interrogatório, que vem sendo aperfeiçoada ao longo dos anos.

Ao longo deste trabalho, buscou-se, antes de analisar diretamente a problemática acima destacada, construir e demonstrar as bases constitucionais em que se assenta o moderno direito processual penal, de feição nitidamente acusatória, ressaltando a necessidade de uma interpretação dos seus institutos sob uma ótica constitucional e de proteção aos direitos e garantias do acusado e respeito aos princípios fundamentais aplicáveis no âmbito processual penal, conformando um processo justo ao acusado.

Nessa medida, acreditamos que uma mudança tão profunda na estrutura do interrogatório, não mais permitindo a inquirição do acusado perante o magistrado que o irá sentenciar ao final do feito, tendo como conseqüência o 
isolamento do acusado de toda a instrução criminal, já que, agora, esta deverá desenrolar-se, em regra, em apenas um dia, deve ser analisada tendo como pano de fundo a importância do interrogatório do acusado, seus direitos, garantias e os princípios constitucionais.

Construído todo esse cenário acima apresentado, passou-se a análise dos objetivos que nortearam o surgimento do interrogatório por videoconferência no Brasil, demonstrando sua evolução em nosso país, até culminar com a edição da Lei 11.900/09.

Percebeu-se que, apesar de haver outras questões, os objetivos e argumentos para a adoção de tal medida fundam-se em três aspectos principais, quais sejam, o econômico, o da segurança e o da celeridade processual.

Espera-se, como visto, que o Estado tenha uma grande economia e a possibilidade de afetar tais quantias em outras áreas mais necessitadas. Além disso, objetiva-se uma melhoria na segurança pública, na medida em que não haveria mais fugas ou tentativas de resgates durante o trajeto até o fórum. Por fim, a questão da celeridade nos feitos criminais, não havendo a necessidade de deslocamento do acusado, impedindo uma eventual ausência do mesmo.

Todavia, respeitando-se os argumentos trazidos por esta corrente, que conta com juristas do mais alto escol, acreditamos não serem argumentos suficientes a embasar tal medida, já que violam direitos e garantias do acusado, prejudicando por demais sua defesa em juízo.

É necessário o contato pessoal do acusado com o magistrado, bem como com o membro do Ministério Público e, quando se trate da inquirição em Plenário, com os jurados, que, no fim, serão os que decidirão o destino do 
acusado. Ademais, é necessária a presença do defensor ao seu lado, fato que ainda suscita dúvidas de como se operará na prática, já que, na medida em que vá ao presídio, não poderá acompanhar a audiência e os debates que se travarão durante a audiência, que, é importante ressaltar, agora é una e calcada nos princípios da oralidade e da imediatidade, demandando uma atuação ativa do defensor em juízo.

Além disso, buscou-se lançar novas luzes na questão da economia, argumento tão disseminado, mostrando-se com dados concretos que a medida pode se tornar mais custosa do que o deslocamento dos presos. É necessário refletir se um investimento tão grande, a fim de equipar salas e mais salas com videoconferência é realmente razoável, já que a videoconferência, como o Código de Processo Penal dispõe, será adotada excepcionalmente, e quando tal fato ocorrer ensejará não só o interrogatório por videoconferência, mas a necessidade do acusado assistir a toda instrução criminal por tal sistema, já que a audiência é una e o interrogatório foi deslocado como último ato do procedimento.

Movendo-se para a questão da segurança pública, tema extremamente delicado, resta claro o perigo de sustentar a adoção do interrogatório virtual com tal fundamento, já que a segurança pública, ordem pública, ou qualquer outra expressão utilizada, revela a porosidade e indefinição do seu conteúdo, não permitindo definições claras de quais seriam as situações a embasar tal medida.

No plano da celeridade processual, destaca-se que a Reforma operada pelas Leis $11.689,11.690$ e 11.719, todas de 2008, já trabalharam nessa frente, revendo alguns dos institutos do direito processual penal, especificamente no tocante ao procedimento, objetivando torná-lo mais célere e eficaz. Além 
disso, deve-se ter em conta que estamos no âmbito do processo penal, onde o bem liberdade está em jogo, de modo que de nada adianta ter um processo extremamente célere e objetivo e, lado contrário, não fornecer os meios de defesa adequado e suficientes ao acusado, privando-o de sua liberdade sem um processo justo.

Deve ser ressaltado que o processo penal não deve se fechar às inovações tecnológicas trazidas pela modernidade, mantendo-se estagnado na evolução do processo. Ao contrário; novas tecnologias devem sempre receber acolhida e serem estudas com cuidado. Todavia, um limite é necessário a tais inovações, na medida em que tangenciem de modo significativo os direitos, garantias do acusado e a possibilidade do exercício de uma defesa de qualidade, contando o réu com todos os meios ao seu dispor.

Por fim, não se pode sobrepor a tecnologia ao direito de defesa, sob pena de esvaziá-lo substancialmente, violando, conseqüentemente, os princípios do devido processo legal, ampla defesa e do contraditório, de alçada constitucional e aplicação direta no processo penal, e que devem ser sempre observados quando da implementação de novas medidas no seio do processo penal. 


\section{REFERÊNCIAS BIBLIOGRÁFICAS:}

ARAS, Vladimir. Sociedade Digital. Teleinterrogatório não elimina nenhuma garantia processual. Disponível em: 〈www.conjur.com.br $\rangle$.

ARAS, Vladimir. Videoconferência no Processo Penal. Disponível em $\langle\underline{w w w . j u s n a v e g a n d i . c o m . b r}\rangle$.

BADARÓ, Gustavo Henrique Righi Ivahy. A lei estadual n. 11.819, de 05/01/05, e o interrogatório por videoconferência: primeiras impressões. Disponível em: 〈www.ibccrim.com.br $>$.

BARROSO, Luís Roberto. O Controle de Constitucionalidade no Direito Brasileiro - Exposição Sistemática da Doutrina e Análise Crítica da Jurisprudência. $2^{\mathrm{a}}$ ed. São Paulo: Saraiva, 2005.

BARROSO, Luís Roberto. Temas de Direito Constitucional. $1^{\mathrm{a}}$ ed. Rio de Janeiro: Renovar, 2001.

BASTOS, Celso Ribeiro. Curso de Direito Constitucional. $18^{\mathrm{a}}$ ed. São Paulo: Saraiva, 1997.

BECCARIA, Cesare. Dos Delitos e das Penas. $1^{a}$ ed. São Paulo: Rideel, 2003.

BEZERRA, Ana Cláudia da Silva. Interrogatório on-line e a ampla defesa. Disponível em: <http://sisnet.aduaneiras.com.br/lex/doutrinas/arquivos/interrogatorio.pdf $>$ 
CAMÂRA, Alexandre. Lições de Direito Processual Civil, v.I, 16 a ed. Rio de Janeiro: Lumen Juris, 2007.

CAPEZ, Fernando. Interrogatório por videoconferência. São Paulo: Complexo Jurídico Damásio de Jesus, jan. 2009. Disponível em: <wWw.damasio.com.br $>$.

CASTRO, Carlos Roberto Siqueira. O Devido Processo Legal e os Princípios da Razoabilidade e da Proporcionalidade. $3^{\mathrm{a}}$ ed. Rio de Janeiro: Forense, 2005.

CASTRO, Carlos Roberto Siqueira. Resistência ao uso de novas tecnologias não se justifica. Tribuna do Advogado. Seccional da Ordem dos Advogados do Brasil no Rio de Janeiro. Ano XXXVI, Mar. 2009, $\mathrm{n}^{\circ}$ 447. p. 19.

CHOUKR, Fauzi Hassan. Código de Processo Penal: Comentários Consolidados e Crítica Jurisprudencial. $2^{\mathrm{a}}$ ed., Rio de Janeiro: Lumen Juris, 2007.

CHOUKR, Fauzi Hassan. Processo penal à luz da Constituição, São Paulo: Edipro, 1999.

CRUZ E TUCCI, José Rogério. Constituição de 1988 e Processo. Regramentos e garantias constitucionais do processo. $1^{\mathrm{a}}$ ed. São Paulo: Saraiva, 1989.

D’URSO, Luiz Flávio Borges. Lei da Videoconferência ameaça ampla defesa. Disponível em: 〈www.conjur.com.br〉. 
DIDIER, Fredie. Curso de Direito Processual Civil, v.I. $9^{\mathrm{a}}$ ed. Bahia: JusPODIVM, 2008.

DIDIER, Fredie. Editorial $n^{o}$ 40. Disponível em <www.frediedidier.com.br $>$

FERNANDES, Antônio Scarance. Processo Penal Constitucional. $3^{\mathrm{a}}$ ed. São Paulo: Revista dos Tribunais, 2002.

FILHO, Fernando da Costa Tourinho. Processo Penal, v. III, $27^{\mathrm{a}}$ ed. São Paulo: Saraiva, 2005.

FILHO, Fernando da Costa Tourinho. Processo Penal, v.I. 29a ed. São Paulo: Saraiva, 2007.

FIOREZE, Juliana. Videoconferência no Processo Penal Brasileiro: Interrogatório On-Line. Paraná: Juruá, 2008.

GOMES, Abel Fernandes et al. Persecução Penal e Devido Processo Legal no Brasil e na Common Law Tradition - Análise Histórica e Comparativa à Luz da Aplicação de Princípios Democráticos. In: Revista da Seção Judiciária do Rio de Janeiro. n. 22. jun. 2008.

GOMES, Luiz Flávio. Uso da videoconferência na Justiça. Boletim do Instituto Brasileiro de Ciências Criminais - IBCCRIM. n. 42, jun.1996.

GOMES, Luiz Flávio. O Uso da Videoconferência na Justiça Brasileira. 2007. Disponível em: 〈www.lfg.com.br〉. 
GOMES, Luiz Flávio et al. Comentários às Reformas do Código de Processo Penal e da Lei de Trânsito. $1^{\mathrm{a}}$ ed. São Paulo: Revista dos Tribunais, 2008.

GOMES FILHO, Antônio Magalhães. Garantismo à paulista: a propósito da videoconferência. Disponível em: 〈www.ibccrim.org.br〉.

GRANDINETTI, Luis Gustavo. O Processo Penal em Face da Constituição - Princípios Constitucionais do Processo Penal. $2^{\mathrm{a}}$ ed. Rio de Janeiro: Lumen Juris, 1998.

GRECO, Rogério. Curso de Direito Penal. Parte Geral. v.I. Rio de Janeiro: Impetus, 2008.

GRINOVER, Ada Pelegrini. Novas Tendências do Direito Processual de Acordo com a Constituição de 1988. Rio de Janeiro: Forense Universitária, 1990.

GRINOVER, Ada Pellegrini. Teoria Geral do Processo. In O Processo em Evolução. 2a Ed. Rio de Janeiro: Forense, 1998.

GRINOVER, Ada Pelegrini et al. As Nulidades no Processo Penal. $8^{\mathrm{a}}$ ed. São Paulo: Revista dos Tribunais, 2004.

GRINOVER, Ada Pelegrini. Teoria Geral do Processo. $21^{\mathrm{a}}$ ed. São Paulo: Malheiros, 2005.

JARDIM, Afrânio Silva. “Juizados Especiais Criminais". In: Direito Processual Penal. $8^{\text {a }}$ ed., Rio de Janeiro: Forense, 1999. 
JARDIM, Afrânio Silva. Ação Penal Pública - Princípio da Obrigatoriedade. $1^{\mathrm{a}}$ ed. Rio de Janeiro: Forense, 1988.

JR, Aury Lopes. O Interrogatório On Line no processo penal: entre a assepsia judiciária e o sexo virtual. Disponível em: <wwW.ibccrim.com.br $>$.

JÚNIOR, Aury Lopes. Propostas para um novo modelo de persecução penal-Combate à impunidade. Disponível em <http://www.cjf.jus.br/revista/SerieCadernos/Vol25/tema03.pdf. $>$

JÚNIOR, Humberto Theodoro. Curso de Direito Processual Civil, v.I, $44^{\mathrm{a}}$ ed. Rio de Janeiro: Forense, 2006

JÚNIOR, Nelson Nery. Código de Processo Civil Comentado e Legislação Extravagante. $7^{\mathrm{a}}$ ed. São Paulo: Revista dos Tribunais, 2003.

LENZA, Pedro. Direito Constitucional Esquematizado. $12^{\text {a }}$ ed, São Paulo: Saraiva, 2008.

LIMA, Marcellus Polastri. Curso de Processo Penal, v. III. $2^{\mathrm{a}}$ ed. Rio de Janeiro: Lumen Juris, 2006.

MADELENA, Pedro. Videoconferência: Interrogatório. Disponível em <www.amb.com.br>.

MAIEROVITHC, Walter. Crime organizado. Turismo Judiciário no Brasil. Disponível em <www.ibgf.org.br> 
MAIEROVITHC, Walter. São Paulo virou uma Bagdá. Disponível em: 〈wWw.oglobo.com.br $>$.

MIRABETE, Júlio Fabbrini. Processo Penal. $2^{\text {a }}$ ed. São Paulo: Atlas S.A., 1992.

MOREIRA, Rômulo de Andrade. A Reforma do Código de Processo Penal - Procedimentos. Disponível em <www.ibccrim.com.br>.

NALINI, Leandro. Visão Provinciana impede a evolução da videoconferência. Disponível em: 〈www.conjur.com.br $>$.

NAVES, Nilson. Direito e Tecnologia da Informação. Disponível em: < http://www.cjf.jus.br/revista/numero19/artigo1.pdf>.

NUCCI, Guilherme de Souza. Manual de Processo Penal e Execução Penal. $3^{\mathrm{a}}$ ed. São Paulo: Revista dos Tribunais, 2007.

OLIVEIRA, Eugênio Pacelli de. Curso de Processo Penal. $10^{\mathrm{a}}$ ed. Rio de Janeiro: Lumen Juris, 2008.

PEREIRA, Jane Reis Gonçalves; SILVA, Fernanda Duarte Lopes Lucas da. A Estrutura Normativa das Normas Constitucionais. Notas sobre a Distinção entre Princípios e Regras. In: GUERRA, Isabella Franco; PEIXINHO, Manoel Messias (Org.). Os Princípios da Constituição de 1988. $2^{a}$ ed. Rio de Janeiro: Lumen Juris, 2006.

PIMENTA, Haroldo. O Contraditório e a prova no processo penal.: breves comentários à Lei 11.690, de 2008. Disponível em: < http://www.ejef.tjmg.jus.br/home/> 
PINTO, Ronaldo Batista. Interrogatório on-line ou virtual. Constitucionalidade do ato e vantagens em sua aplicação. Disponível em: <www.jusnavegandi.com.br >

PIOVESAN, Flávia. Direitos Humanos e o Direito Constitucional Internacional. $8^{\text {a }}$ ed. São Paulo: Saraiva, 2007.

PRADO, Geraldo. Sistema Acusatório. A Conformidade Constitucional das Leis Processuais Penais. Rio de Janeiro: Lumen Juris, 1999.

RAMALHO, PAULO. Perversidade, imoralidade e discriminação. Tribuna do Advogado. Seccional da Ordem dos Advogados do Brasil no Rio de Janeiro. Ano XXXVI, Mar. 2009, n 447. p. 19.

RANGEL, Paulo. Direito Processual Penal. $16^{\mathrm{a}}$ ed. Rio de Janeiro: Lumen Juris, 2009.

SANTOS, Moacyr Amaral. Primeiras Linhas de Direito Processual Civil. vl.1. $23^{\mathrm{a}}$ ed, São Paulo: Saraiva, 2004.

SARMENTO, Daniel. Livres e Iguais - Estudos de Direito Constitucional. $1^{a}$ ed. Rio de Janeiro: Lumen Juris, 2006.

SILVA, José Afonso da. Curso de Direito Constitucional Positivo. $2^{\mathrm{a}}$ ed. São Paulo: Revista dos Tribunais, 1984.

STF, HC nº 88.914, Rel. Ministro Cezar Peluso, Brasília, 14 ago. 2007. 
STF, HC nº 90.900, Rel. Ministra Ellen Gracie, 30 out. 2008.

STF, Questão de Ordem no Inq. $n^{\circ}$ 1.957, Rel. Ministro Carlos Velloso, Brasília, 11 de mai. 2005.

STF, Rel. Ministro Celso de Mello, Habeas Corpus no 94.016-1, Brasília, Julgamento 16 set. 2008

TORNAGHI, Hélio. Curso de Processo Penal, vl. 1. São Paulo: Saraiva, 1980.

TOVIL, Joel. A Proteção contra a auto-acusação compulsória aplicada à persecução penal. In: LIMA, Marcellus Polastri (Org.), MORAES, Bruno Ribeiro (Org.). Estudos Criminais em Homenagem a Weber Martins Batista. Rio de Janeiro: Lumen Júris, 2008.

WAMBIER, Luiz Rodrigues. Curso Avançado de Processo Civil. vl.1. $7^{\mathrm{a}}$ ed. São Paulo: Revista dos Tribunais, 2005. 